\title{
The Role of the Conserved SUMO-2/3 Cysteine Residue on Domain Structure Investigated Using Protein Chemical Synthesis
}

Jennifer Bouchenna, ${ }^{a}$ Magalie Sénéchal, ${ }^{a}$ Hervé Drobecq, ${ }^{a}$ Nicolas Stankovic-Valentin, ${ }^{b}$ Jérôme Vicogne, ${ }^{* a}$ Oleg Melnyk*a

${ }^{\text {a }}$ University of Lille, CNRS, Institut Pasteur de Lille, INSERM, UMR CNRS 8204, Centre d'Immunité et d'Infection de Lille, F-59000 Lille, France.

${ }^{\text {b }}$ Zentrum für Molekulare Biologie der Universität Heidelberg (ZMBH), DKFZ - ZMBH Alliance, 69120, Heidelberg, Germany.

email of corresponding authors:

oleg.melnyk@ibl.cnrs.fr

jerome.vicogne@ibl.cnrs.fr 


\section{Table of content}

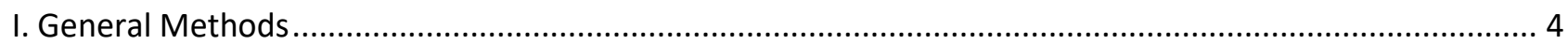

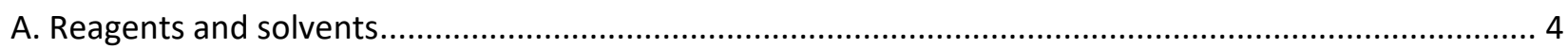

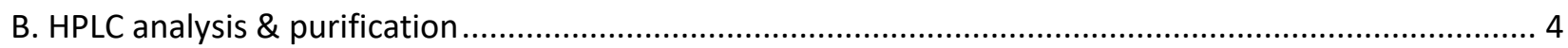

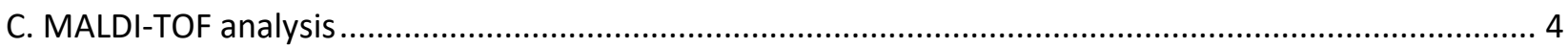

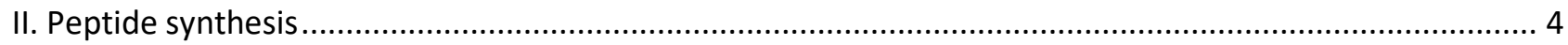

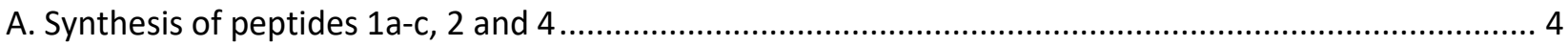

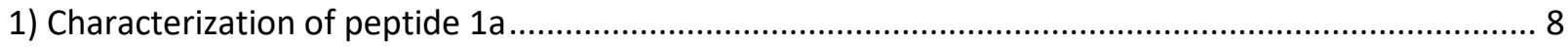

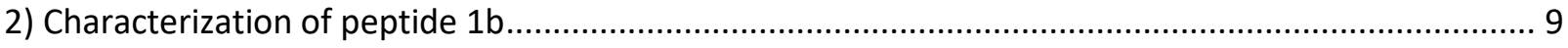

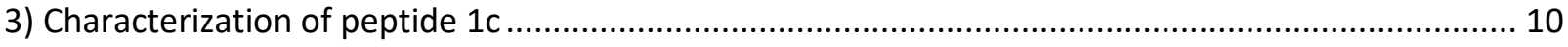

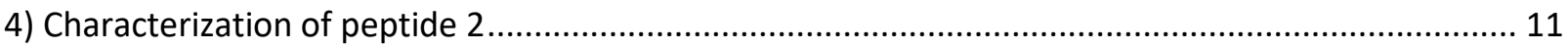

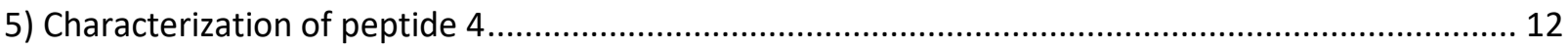

B. Synthesis of peptide thioesters by thiol-SEA exchange …............................................................. 13

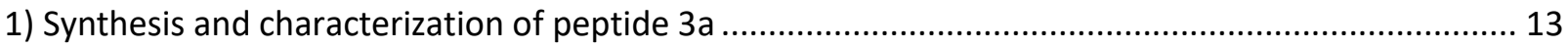

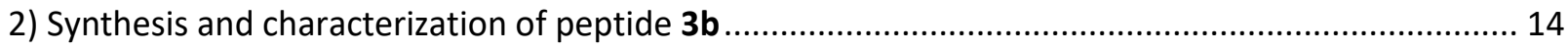

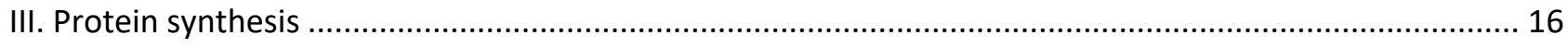

A. Chemical synthesis of SUMO-2, SUPO-3 and SUMO-2/3 core proteins........................................... 16

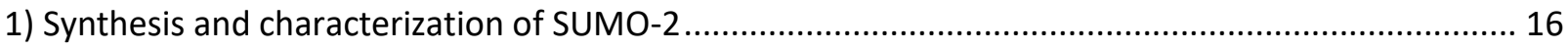

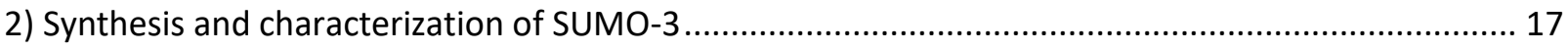

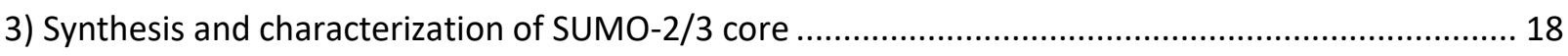

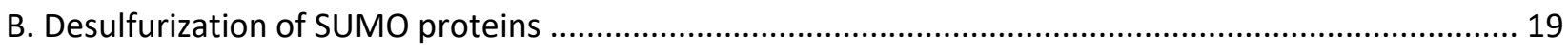

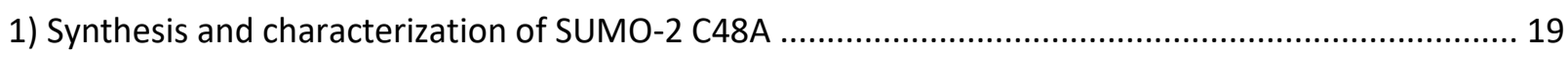

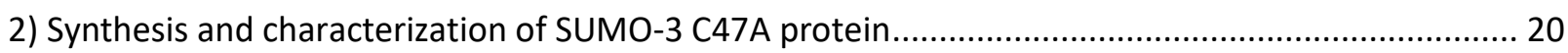

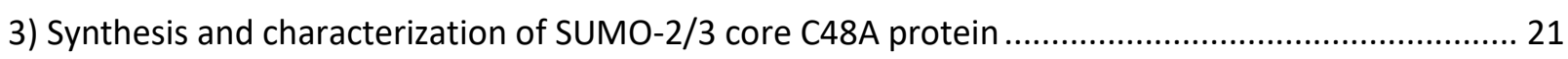

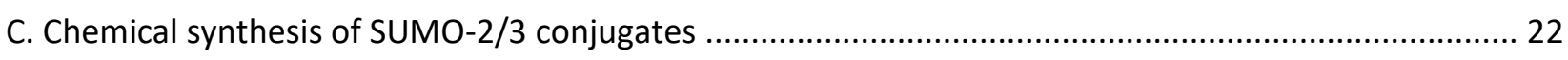

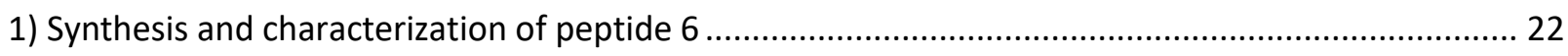

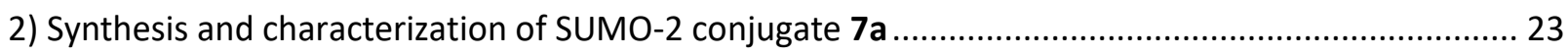

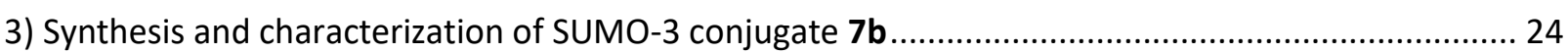

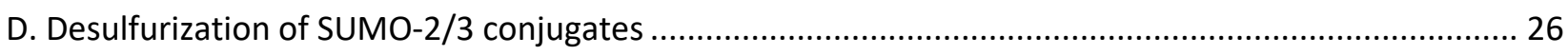

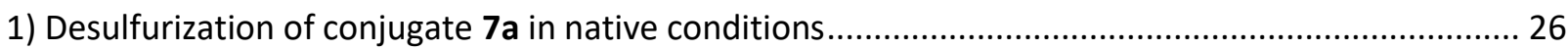

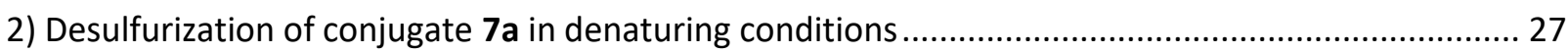

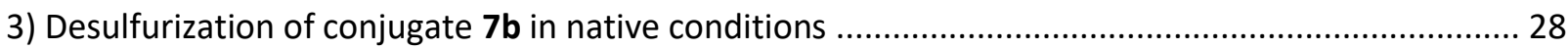

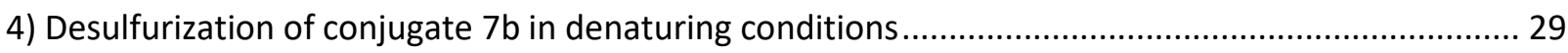

IV. Proteomics analysis of recombinant SUMO-2 and 3 proteins and SUMO conjugates ........................... 30

1) Proteomic analysis of $r_{1}$-SUMO-2 \& 3 Boston Biochem (ref. UL-752 \& UL-762)................................ 30

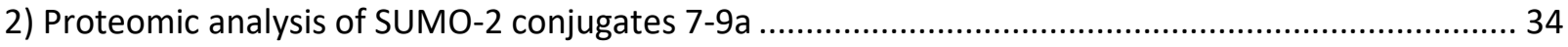




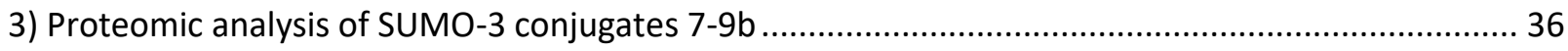

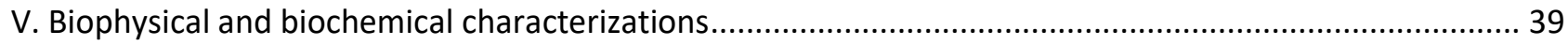

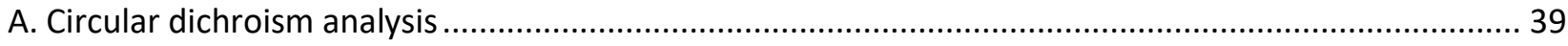

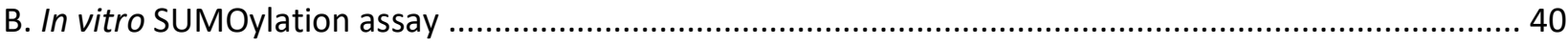

C. Fluorescence Resonance Energy Transfert (FRET) analysis.............................................................. 42

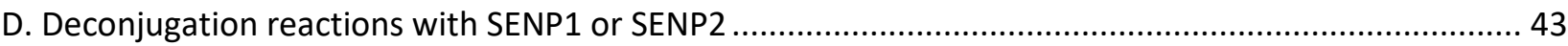

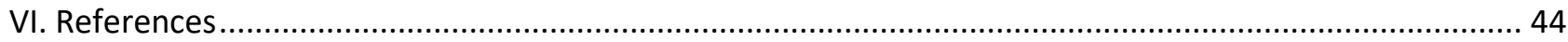




\section{General Methods}

\section{A. Reagents and solvents}

$\mathrm{N}$-[(dimethylamino)-1H-1,2,3-triazolo-[4,5-b]pyridin-1-ylmethylene]- $\mathrm{N}$-methylmethanaminium hexafluorophosphate $\mathrm{N}$-oxide (HATU) and $\mathrm{N \alpha}$-Fmoc protected amino acids were obtained from Iris Biotech $\mathrm{GmbH}$. Sidechain protecting groups used for the amino acids were Fmoc-Ala-OH, Fmoc-Arg(Pbf)-OH, Fmoc-Asn(Trt)-OH, Fmoc-Asp(OtBu)-OH, Fmoc-Asp(OtBu)[Dmb-Gly]-OH, Fmoc-Gln(Trt)-OH, Fmoc-Glu(OtBu)-OH, Fmoc-Gly-OH, Fmoc-His(Trt)-OH, Fmoc-lle-OH, Fmoc-Leu-OH, Fmoc-Lys(Boc)-OH, Fmoc-Met-OH, Fmoc-Phe-OH, Fmoc-Pro$\mathrm{OH}$, Fmoc-Ser(OtBu)-OH, Fmoc-Thr(OtBu)-OH, Fmoc-Tyr(OtBu)-OH, Fmoc-Val-OH, Fmoc-Cys(StBu)-OH or Fmoc-Cys(Trt)-OH.

Synthesis of bis(2-sulfanylethyl)aminotrityl polystyrene (SEA PS) resin was carried out as described elsewhere. ${ }^{1,2}$ 4-mercaptophenylacetic acid (MPAA) and tris (2-carboxyethyl)phosphine hydrochloride (TCEP) were purchased from Sigma-Aldrich. All other reagents were purchased from Acros Organics or Merck and were of the purest grade available. Peptide synthesis grade $\mathrm{N}, \mathrm{N}$-dimethylformamide (DMF), dichloromethane $\left(\mathrm{CH}_{2} \mathrm{Cl}_{2}\right)$, diethyl ether $\left(\mathrm{Et}_{2} \mathrm{O}\right)$, acetonitrile $\left(\mathrm{CH}_{3} \mathrm{CN}\right)$, heptane, $\mathrm{LC}-\mathrm{MS}$-grade acetonitrile $\left(\mathrm{CH}_{3} \mathrm{CN}, 0.1 \%\right.$ TFA and $\mathrm{CH}_{3} \mathrm{CN}, 0.1 \%$ formic acid), LC-MS-grade water $\left(\mathrm{H}_{2} \mathrm{O}, 0.1 \%\right.$ TFA and $\mathrm{H}_{2} \mathrm{O}, 0.1 \%$ formic acid), $\mathrm{N}, \mathrm{N}$-diisopropylethylamine (DIEA), acetic anhydride $\left(\mathrm{Ac}_{2} \mathrm{O}\right)$ were purchased from Biosolve and Fisher-Chemical. Trifluoroacetic acid (TFA) was obtained from Biosolve. Water was purified with a Milli-Q Ultra Pure Water Purification System.

\section{B. HPLC analysis \& purification}

The reactions were monitored by analytical UPLC-MS (Dionex UltiMate 3000 LC/ LCQ Fleet lon Trap) on a reverse phase column. The column, eluent system and gradient used are indicated in the figure legends. The column eluate was monitored with a Dionex DA detector $(215 \mathrm{~nm}, 280 \mathrm{~nm})$ and Corona Veo charged aerosol detector. The peptide masses were measured by on-line UPLC-MS: lonization mode: ES+, m/z range 3002000 , capillary voltage $2.8 \mathrm{kV}$, cone voltage $10 \mathrm{~V}$, tube lens $75 \mathrm{~V}$, capillary voltage temperature $350^{\circ} \mathrm{C}$. Ligations were analyzed by quenching aliquots $(2 \mu \mathrm{L})$ of the reaction mixtures with $100 \mu \mathrm{L}$ of $10 \%$ aqueous acetic acid. The mixture was extracted with $\mathrm{Et}_{2} \mathrm{O}$ to remove MPAA before analysis.

\section{MALDI-TOF analysis}

MALDI-TOF mass spectra were recorded with a BrukerAutoflex Speed mass spectrometer. The matrix used for the analysis is indicated in the figure legends. The peptides were purified by semi-preparative HPLC (Waters 600 controller, UV 2487 Detector, $215 \mathrm{~nm}$, TL 105 HPLC column heater) on a reverse phase column (Waters XBridge BEH300 C18, $10 \times 250 \mathrm{~mm}$; pore size $300 \AA$; particle size : $5 \mu \mathrm{m}$ ). The eluent system and gradient used are indicated in the figure legends.

\section{Peptide synthesis}

\section{A. Synthesis of peptides $1 a-c, 2$ and 4}

Peptide 1a: ADEKPKEGVKTENNDHINLKVAGQDGSVVQFKIKRHTPLSKLMKAY-SEA ${ }^{\text {off }}$

Peptide 1b: SEEKPKEGVKTENDHINLKVAGQDGSVVQFKIKRHTPLSKLMKAY-SEA ${ }^{\text {off }}$

Peptide 1c: DHINLKVAGQDGSVVQFKIKRHTPLSKLMKAY-SEA ${ }^{\text {off }}$

Peptide 2: CERQGLSMRQIRFRFDGQPINETDTPAQLEMEDEDTIDVFQQQTGG

Peptide 4: C(StBu)ERQGLSMRQIRFRFDGQPINETDTPAQLEMEDEDTIDVFQQQTGG-SEA ${ }^{\text {off }}$ 
Coupling of the first amino acid residue to the SEA ChemMatrix resin and HMPA ChemMatrix resin

The first amino acid was coupled manually to the SEA ChemMatrix ${ }^{\circledR}$ resin for SEA peptides (Scheme S 1A) or to the HMPA ChemMatrix ${ }^{\circledR}$ resin for peptide acids (Scheme S 1B) using HATU/DIEA activation in DMF.

Scheme S 1. Loading of the first amino acid on the resin. A) Loading on SEA ChemMatrix $®$ resin. B) Loading on HMPA ChemMatrix ${ }^{8}$ resin

A)

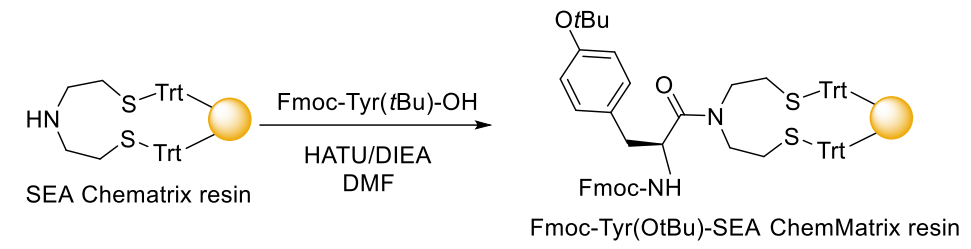

B)
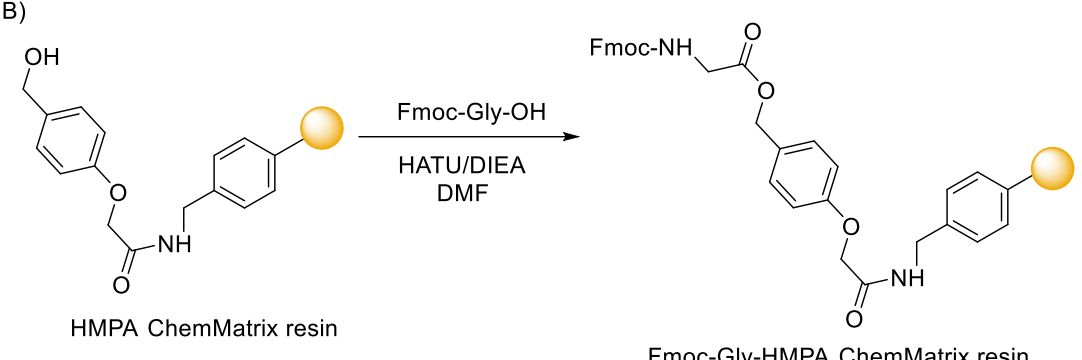

Fmoc-Gly-HMPA ChemMatrix resin

SEA ChemMatrix resin $(0.220 \mathrm{mmol} / \mathrm{g}, 454 \mathrm{mg}, 100 \mu \mathrm{mol})$ was conditioned in $\mathrm{CH}_{2} \mathrm{Cl}_{2}(3 \times 2 \mathrm{~min}, 3 \mathrm{~mL})$ and then in DMF $(3 \times 2 \mathrm{~min}, 3 \mathrm{~mL})$ in a manual SPPS glass reactor.

Fmoc-Tyr(OtBu)-OH (460 mg, $1.00 \mathrm{mmol}$ ) and HATU $(376 \mathrm{mg}, 0.950 \mathrm{mmol}$ ) was dissolved in the minimal volume of DMF ( $2 \mathrm{~mL}$ ). DIEA ( $348 \mu \mathrm{L}, 2.00 \mathrm{mmol}$ ) was added to the above solution to start the activation of the amino acid. This solution was agitated for $1 \mathrm{~min}$ and then added to the resin which was shaken during $1 \mathrm{~h} 30$ min at room temperature. The resin was subsequently washed with DMF $(5 \times 2 \mathrm{~min}, 3 \mathrm{~mL})$. The chloranil assay was negative. The resin was then acetylated with a mixture of acetic anhydride/DIEA/DMF: 10/5/85 by vol $(2 \times 3 \mathrm{~mL}, 2 \mathrm{~min}$ and then $20 \mathrm{~min}$ ) before being washed successively with DMF ( $3 \times 2 \mathrm{~min}, 3 \mathrm{~mL}), \mathrm{CH}_{2} \mathrm{Cl}_{2}$ $(3 \times 2 \mathrm{~min}, 3 \mathrm{~mL})$ and diethyl ether $(3 \times 2 \mathrm{~min}, 3 \mathrm{~mL})$. The resin was finally dried in vacuo for $\sim 2 \mathrm{~h}$.

HMPA ChemMatrix resin (500 mg, Lot 08k11-20-03-043) was conditioned in $\mathrm{CH}_{2} \mathrm{Cl}_{2}$ (3 $\times 2 \mathrm{~min}, 3 \mathrm{~mL}$ ), in DMF $(3 \times 2 \mathrm{~min}, 3 \mathrm{~mL})$ and then in $\mathrm{CH}_{2} \mathrm{Cl}_{2}(3 \times 2 \mathrm{~min}, 2 \mathrm{~mL})$ in a manual SPPS glass reactor.

Fmoc-Gly-OH ( $297 \mathrm{mg}, 1.00 \mathrm{mmol}$ ) was dissolved in $\mathrm{CH}_{2} \mathrm{Cl}_{2} / \mathrm{DMF}$ ( $15 / 1$ by vol, $7 \mathrm{~mL}$ ) to which was added $N, N^{\prime}-$ diisopropylcarbodiimide (DIC, $78.3 \mu \mathrm{L}, 0.500 \mathrm{mmol}$ ) to start the activation. After $15 \mathrm{~min}$, 4-dimethylaminopyridine (DMAP, $12.2 \mathrm{mg}, 0.100 \mathrm{mmol}$ ) was added to the above solution, which was agitated for $1 \mathrm{~min}$ and then added to the resin. The resin was shaken for $1 \mathrm{~h} 30 \mathrm{~min}$ at room temperature, and subsequently washed with DMF ( $5 \times 2 \mathrm{~min}, 3 \mathrm{~mL}$ ). The resin was then acetylated with a mixture of acetic anhydride/DIEA/DMF: $10 / 5 / 85$ by vol $(2 \times 3 \mathrm{~mL}, 2 \mathrm{~min}$ and then $20 \mathrm{~min}$ ) before being washed successively with DMF ( $3 \times 2 \mathrm{~min}, 3$ $\mathrm{mL}), \mathrm{CH}_{2} \mathrm{Cl}_{2}(3 \times 2 \mathrm{~min}, 3 \mathrm{~mL})$ and diethyl ether $(3 \times 2 \mathrm{~min}, 3 \mathrm{~mL})$. The resin was finally dried in vacuo for $\sim 2 \mathrm{~h}$. 
The loading of the resins was determined by UV quantification at $290 \mathrm{~nm}$ of the dibenzofulvene-piperidine adduct formed by treating aliquots of the resin with piperidine ( $20 \%$ by vol in DMF). We found $0.58 \mathrm{mmol} / \mathrm{g}$ for Fmoc-Gly-HMPA ChemMatrix resin and $0.18 \mathrm{mmol} / \mathrm{g}$ for Fmoc-Tyr(OtBu)-SEA ChemMatrix resin.

\section{Automated solid phase peptide synthesis}

The peptide elongation step was performed using an automated column peptide synthesizer and standard Fmoc-SPPS protocols $(0.1 \mathrm{mmol}$ scale). The amino acids (10 equiv) were activated using HATU (9.9 equiv)/DIEA (20 equiv) in DMF. The peptidyl resin was acetylated with $\mathrm{Ac}_{2} \mathrm{O} / \mathrm{DIEA} / \mathrm{DMF} 10 / 5 / 85$ by vol after each coupling step.

\section{Coupling of the dipeptide unit Fmoc-Asp(OtBu)-(Dmb)Gly-OH}

Fmoc-Asp(OtBu)-(Dmb)Gly-OH (186 mg, $0.300 \mathrm{mmol}, 3$ equiv) and HATU (108 mg, $0.284 \mathrm{mmol}, 2.85$ equiv) was dissolved in the minimal volume of DMF $(2 \mathrm{~mL})$. DIEA ( $104 \mu \mathrm{L}, 0.600 \mathrm{mmol}, 6$ equiv) was added to the above solution to start the activation of the amino acid. This solution was agitated for $1 \mathrm{~min}$ and then added to the resin which was shaken for $1 \mathrm{~h} 30 \mathrm{~min}$ at room temperature. The resin was subsequently washed with DMF (5 × $2 \mathrm{~min}, 3 \mathrm{~mL})$.

The chloranil assay was negative. An aliquot of the peptidyl resin was also treated with piperidine in DMF (20 $\%$ by vol) and cleaved for $1 \mathrm{~h} 30 \mathrm{~min}$ in a mixture of TFA/triisopropylsilane (TIS)//thioanisole/ $\mathrm{H}_{2} \mathrm{O} /$ thiophenol: 87.5/5/2.5/2.5/2.5 by vol $\left(1 \mathrm{~mL}\right.$ ) for SEA ChemMatrix ${ }^{\circledR}$ resin, or TFA/TIS/ $\mathrm{H}_{2} \mathrm{O} /$ ethanedithiol (EDT): $90 / 5 / 2.5 / 2.5$ by vol $\left(1 \mathrm{~mL}\right.$ ) for HMPA-ChemMatrix ${ }^{\circledR}$ resin. $1 \mu \mathrm{L}$ of the cleavage mixture was diluted with water $(50 \mu \mathrm{L})$ and analyzed by MALDI-TOF to confirm the coupling of the dipeptide unit.

\section{Deprotection and cleavage step}

The peptidyl resins $(0.1 \mathrm{mmol}$ scale) were deprotected and cleaved in a mixture of TFA/TIS/thioanisole/ $\mathrm{H}_{2} \mathrm{O} /$ thiophenol: $87.5 / 5 / 2.5 / 2.5 / 2.5$ by vol $(10 \mathrm{~mL}$ ) for $1 \mathrm{~h} 30 \mathrm{~min}$ (twice) for peptides 1a-c and 4, and in a mixture of TFA/TIS/EDT/ $\mathrm{H}_{2} \mathrm{O}: 90 / 5 / 2.5 / 2.5 / 2.5$ by vol $(10 \mathrm{~mL})$ for $1 \mathrm{~h} 30 \mathrm{~min}$ (twice) for peptide 2 . The crude peptides were precipitated in an ice-cold mixture of $\mathrm{Et}_{2} \mathrm{O} / \mathrm{n}$-heptane : $1 / 1$ by vol ( $200 \mathrm{~mL}$ ) to give 380.2 mg ( $63 \%$ crude) of peptide 1a, $355.1 \mathrm{mg}$ ( $54 \%$ crude) of peptide $1 \mathbf{b}, 366.8 \mathrm{mg}$ ( $42 \%$ crude) of peptide $1 \mathrm{c}$, $246.6 \mathrm{mg}$ ( $42 \%$ crude) of peptide $2,297.1 \mathrm{mg}$ ( $51 \%$ crude) peptide 4 .

\section{Purification of SEA ${ }^{\text {off }}$ peptide segments}

The crude SEA ${ }^{\text {on }}$ peptide segments were dissolved in phosphate buffer/6 $\mathrm{M}$ guanidine hydrochloride (final peptide concentration $\sim 0.25 \mathrm{mM}$ ). lodine solution ( $200 \mathrm{mM}$ in DMSO) was added dropwise until the appearance of a yellow color. After $30 \mathrm{~s}$, dithiothreitol (DTT, $65 \mathrm{mM}$ in water) was added dropwise until the disappearance of the yellow color to quench the excess of iodine. The mixture was then immediately filtered and purified by reversed-phase HPLC.

Gradient used for the HPLC purification: eluent A water containing $0.1 \%$ of TFA, eluent $\mathrm{B} \mathrm{CH}_{3} \mathrm{CN} /$ water : $4 / 1$ by vol containing $0.1 \%$ of TFA, gradient: $0-25 \%$ B in $5 \mathrm{~min}$, then $25-35 \% \mathrm{~B}$ in $40 \mathrm{~min}$, flow rate $6 \mathrm{~mL} / \mathrm{min}, 50$ ${ }^{\circ} \mathrm{C}$, UV detection at $215 \mathrm{~nm}$.

Yield for peptide 1a: $34.4 \mathrm{mg}$ of crude product furnished (11.2 mg, 32\%) of peptide 1a. 
Gradient used for the HPLC purification: eluent $A$ water containing $0.1 \%$ of TFA, eluent $\mathrm{B} \mathrm{CH}_{3} \mathrm{CN} /$ water : $4 / 1$ by vol containing $0.1 \%$ of TFA, gradient: $0-25 \%$ B in $5 \mathrm{~min}$, then $25-35 \%$ B in $40 \mathrm{~min}$, flow rate $6 \mathrm{~mL} / \mathrm{min}, 50$ ${ }^{\circ} \mathrm{C}$, UV detection at $215 \mathrm{~nm}$.

Yield for peptide $\mathbf{1 b}$ : $30.8 \mathrm{mg}$ of crude product furnished (11.2 mg, 36\%) of peptide $\mathbf{1 b}$.

Gradient used for the HPLC purification: eluent A water containing $0.1 \%$ of TFA, eluent $B \mathrm{CH}_{3} \mathrm{CN} /$ water : $4 / 1$ by vol containing $0.1 \%$ of TFA, gradient: $0-25 \%$ B in $5 \mathrm{~min}$, then $25-35 \%$ B in $40 \mathrm{~min}$, flow rate $6 \mathrm{~mL} / \mathrm{min}, 50$ ${ }^{\circ} \mathrm{C}$, UV detection at $215 \mathrm{~nm}$.

Yield for peptide 1c: $30.5 \mathrm{mg}$ of crude product furnished (13.7 mg, 45\%) of peptide 1c.

Gradient used for the HPLC purification: eluent A water containing $0.1 \%$ of TFA, eluent $\mathrm{B} \mathrm{CH}_{3} \mathrm{CN} /$ water : $4 / 1$ by vol containing $0.1 \%$ of TFA, gradient: $0-20 \%$ B in $5 \mathrm{~min}$, then $20-40 \%$ B in $40 \mathrm{~min}$, flow rate $6 \mathrm{~mL} / \mathrm{min}, 50^{\circ} \mathrm{C}$, UV detection at $215 \mathrm{~nm}$.

Yield for peptide 2: $31.3 \mathrm{mg}$ of crude product furnished (10.6 mg, 34\%) of peptide 2.

Gradient used for the HPLC purification: eluent $A$ water containing $0.1 \%$ of TFA, eluent $\mathrm{B} \mathrm{CH}_{3} \mathrm{CN} /$ water : $4 / 1$ by vol containing $0.1 \%$ of TFA, gradient: $0-25 \% \mathrm{~B}$ in $5 \mathrm{~min}$, then $25-45 \% \mathrm{~B}$ in $50 \mathrm{~min}$, flow rate $6 \mathrm{~mL} / \mathrm{min}, 65^{\circ} \mathrm{C}$, UV detection at $215 \mathrm{~nm}$.

Yield for peptide 4: $29.2 \mathrm{mg}$ of crude product furnished (9.6 mg, 32\%) of peptide 4 
1) Characterization of peptide $1 \mathrm{a}$
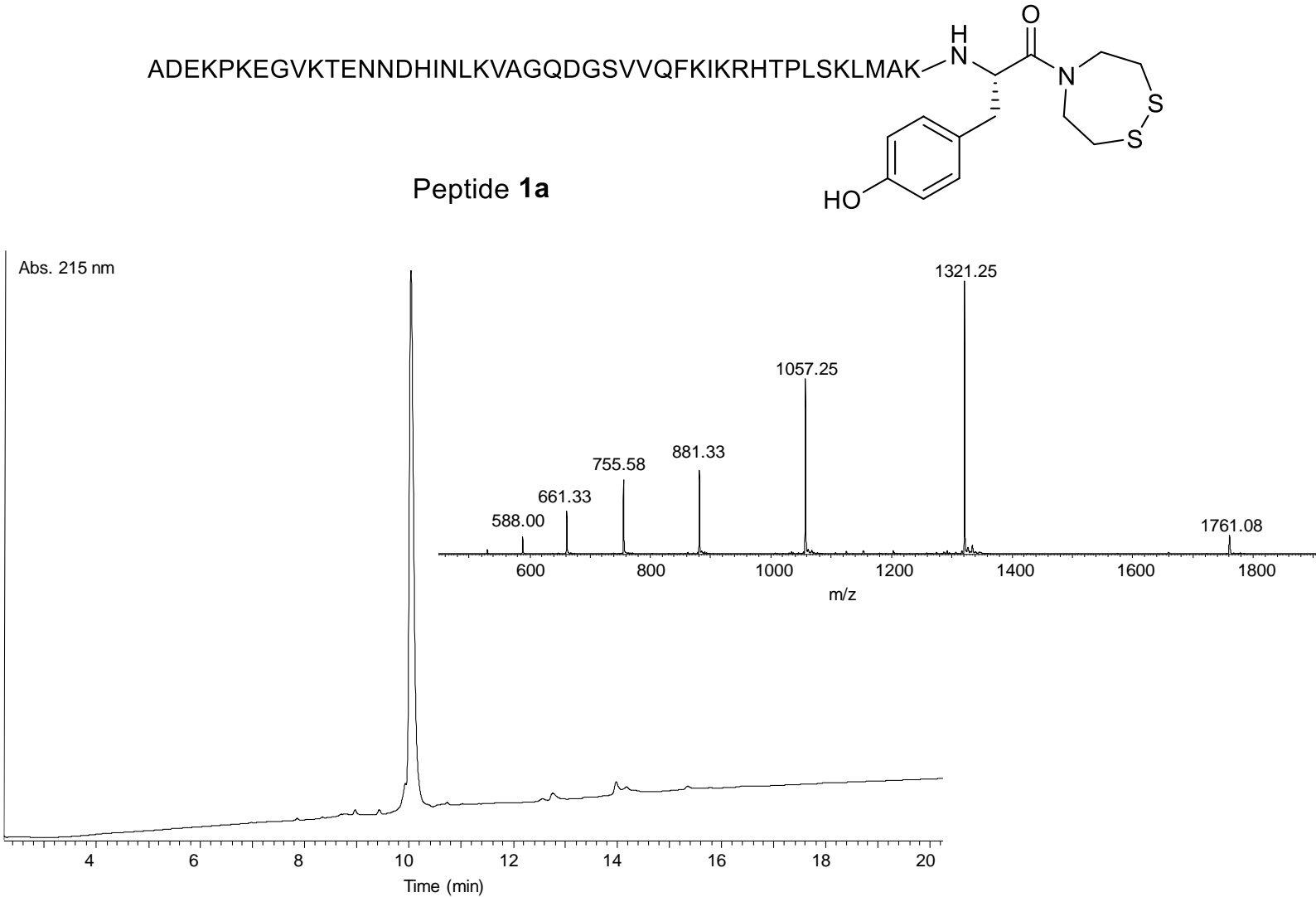

Figure S 1. Analysis of peptide 1a. UPLC-MS analysis ACQUITY UPLC peptide BEH C18 $300 \AA 1.7 \mu \mathrm{m} 2.1 \mathrm{~mm} \times$ $150 \mathrm{~mm}, 50^{\circ} \mathrm{C}$. Flow $0.400 \mathrm{~mL} / \mathrm{min}$, eluent $A 0.1 \%$ trifluoroacetic acid in water, eluent $B 0.1 \%$ trifluoroacetic acid in $100 \%$ acetonitrile. Gradient from $0 \%$ eluent B to $70 \%$ eluent B in 20 min. HPLC trace (UV detection) and MS trace. Calculated for M (average mass) 5281.17, observed 5281.13 after deconvolution 
2) Characterization of peptide $1 \mathrm{~b}$
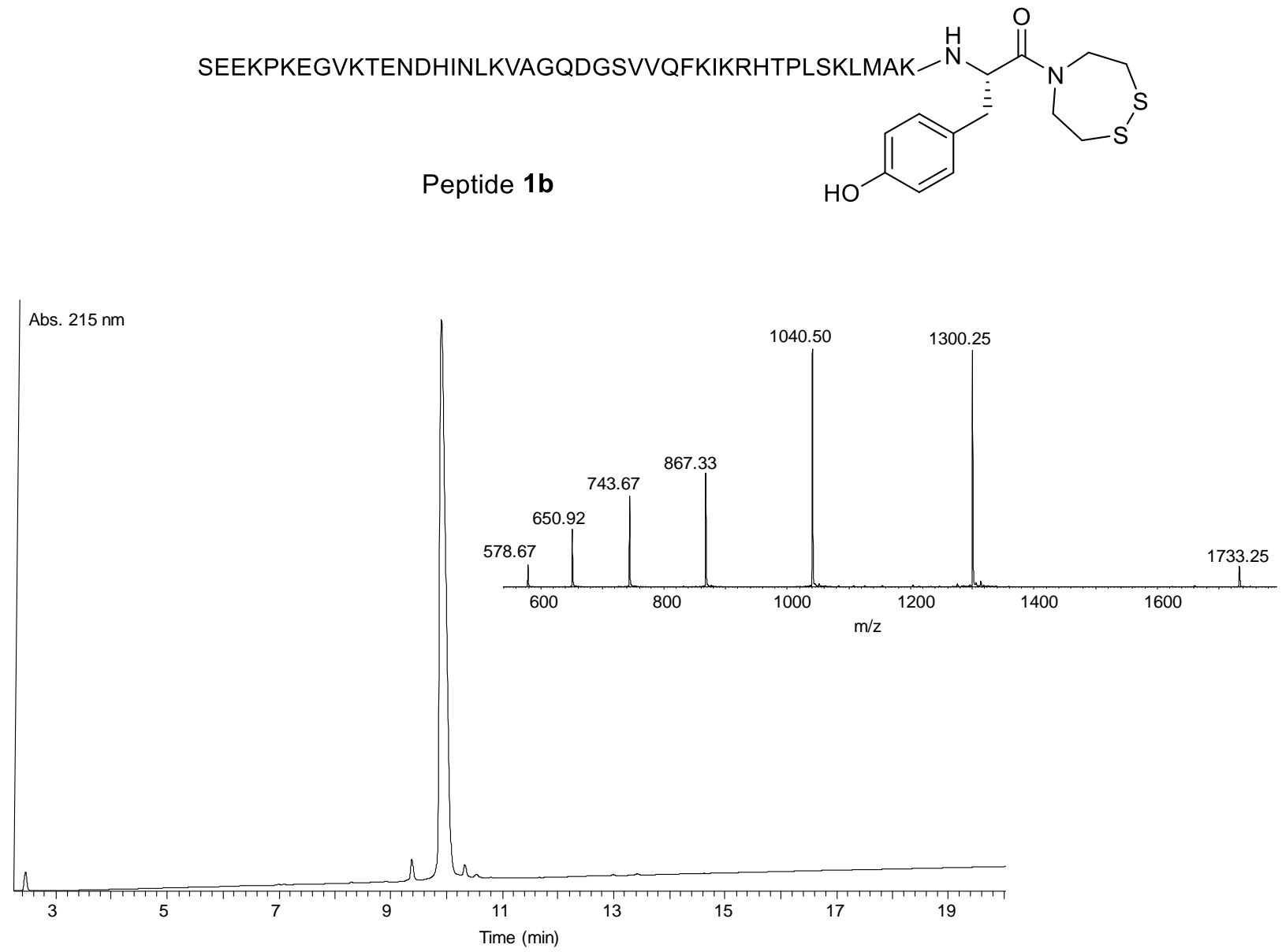

Figure S 2 Analysis of peptide 1b. UPLC-MS analysis ACQUITY UPLC peptide BEH C18 $300 \AA 1.7 \mu \mathrm{m} 2.1 \mathrm{~mm} \times$ $150 \mathrm{~mm}, 50{ }^{\circ} \mathrm{C}$. Flow $0.400 \mathrm{~mL} / \mathrm{min}$, eluent $A 0.1 \%$ trifluoroacetic acid in water, eluent $B 0.1 \%$ trifluoroacetic acid in $100 \%$ acetonitrile. Gradient from $0 \%$ eluent B to $70 \%$ eluent B in 20 min. HPLC trace (UV detection) and MS trace. Calculated for M (average mass) 5197.09, observed 5197.17 after deconvolution. 
3) Characterization of peptide $1 \mathrm{c}$
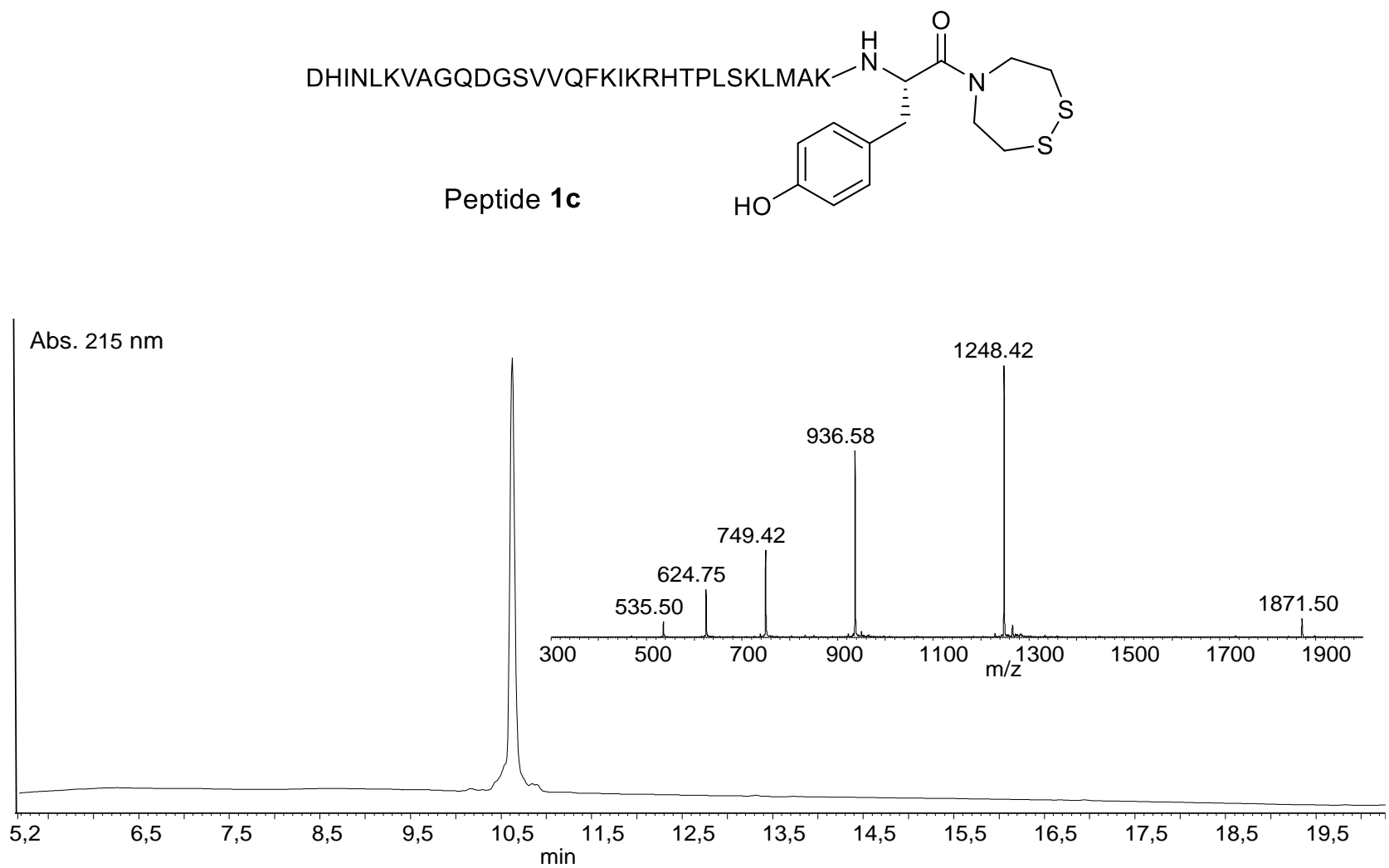

Figure S 3. Analysis of peptide 1c. UPLC-MS analysis ACQUITY UPLC peptide BEH C18 $300 \AA 1.7 \mu \mathrm{m} 2.1 \mathrm{~mm} \times$ $150 \mathrm{~mm}, 50^{\circ} \mathrm{C}$. Flow $0.400 \mathrm{~mL} / \mathrm{min}$, eluent $A 0.1 \%$ trifluoroacetic acid in water, eluent $B 0.1 \%$ trifluoroacetic acid in 100\% acetonitrile. Gradient from 0\% eluent B to 70\% eluent B in 20 min. HPLC trace (UV detection) and MS trace. Calculated for M (average mass) 3741.53, observed 3742.29 after deconvolution. 
4) Characterization of peptide 2

CERQGLSMRQIRFRFDGQPINETDTPAGLEMEDEDTIDVFQQQTGG

Peptide 2

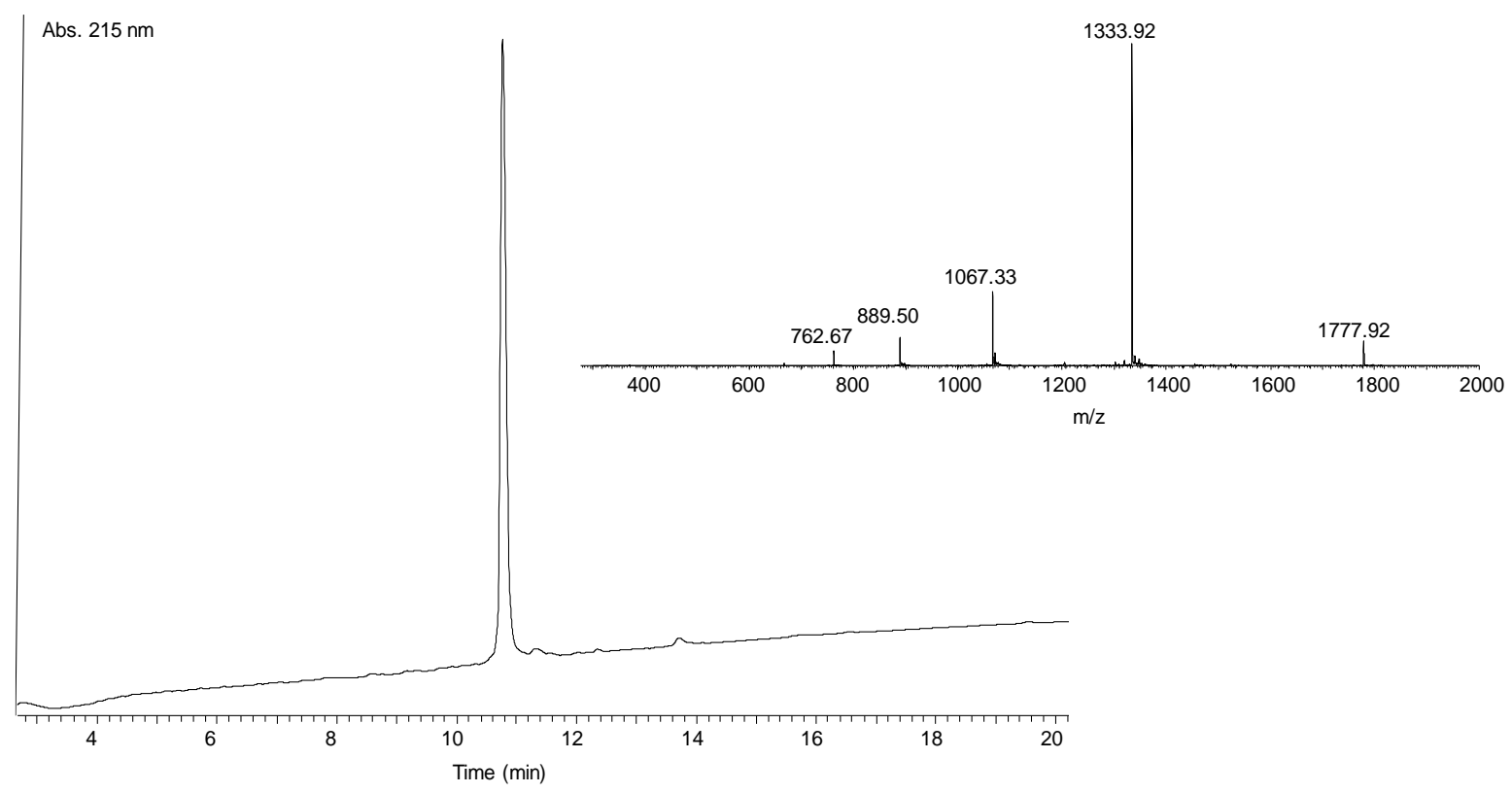

Figure S 4. Analysis of peptide 2. UPLC-MS analysis ACQUITY UPLC peptide BEH C18 $300 \AA 1.7 \mu \mathrm{m} 2.1 \mathrm{~mm} \times$ $150 \mathrm{~mm}, 50{ }^{\circ} \mathrm{C}$. Flow $0.400 \mathrm{~mL} / \mathrm{min}$, eluent $A 0.1 \%$ trifluoroacetic acid in water, eluent $B 0.1 \%$ trifluoroacetic acid in $100 \%$ acetonitrile. Gradient from $0 \%$ eluent B to $70 \%$ eluent B in 20 min. HPLC trace (UV detection) and MS trace. Calculated for M (average mass) 5331.82, observed 5331.95 after deconvolution. 
5) Characterization of peptide 4
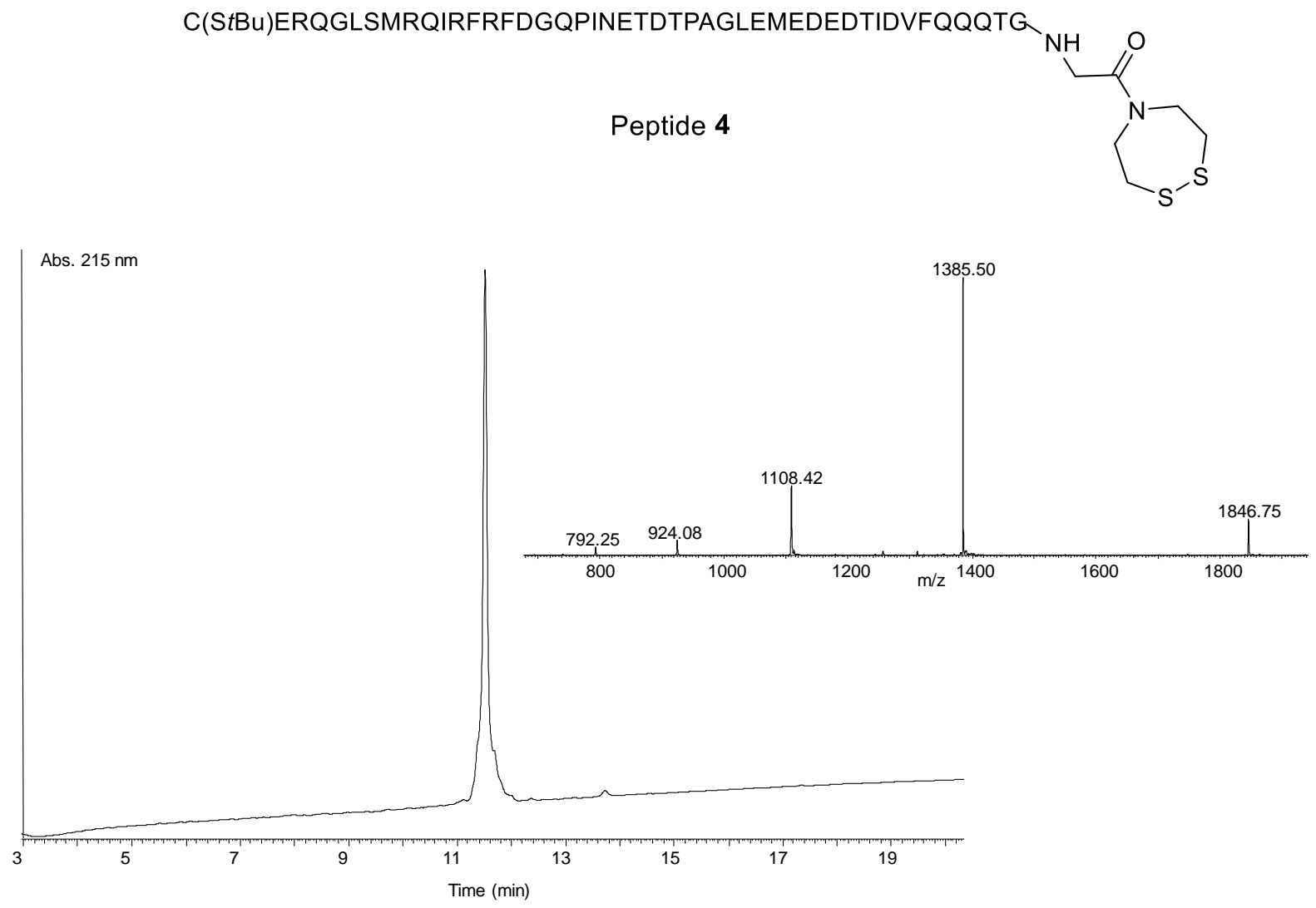

Figure S 5. Analysis of peptide 4. UPLC-MS analysis ACQUITY UPLC peptide BEH C18 $300 \AA 1.7 \mu \mathrm{m} 2.1 \mathrm{~mm} \times$ $150 \mathrm{~mm}, 50^{\circ} \mathrm{C}$. Flow $0.400 \mathrm{~mL} / \mathrm{min}$, eluent $A 0.1 \%$ trifluoroacetic acid in water, eluent $B 0.1 \%$ trifluoroacetic acid in 100\% acetonitrile. Gradient from 0\% eluent B to $70 \%$ eluent B in 20 min. HPLC trace (UV detection) and MS trace Calculated for M (average mass) 5537.21, observed 5537.59 after deconvolution. 


\section{B. Synthesis of peptide thioesters by thiol-SEA exchange}

1) Synthesis and characterization of peptide $3 a$

Scheme S 2. SEA-thiol exchange reaction for the preparation of peptide thioester

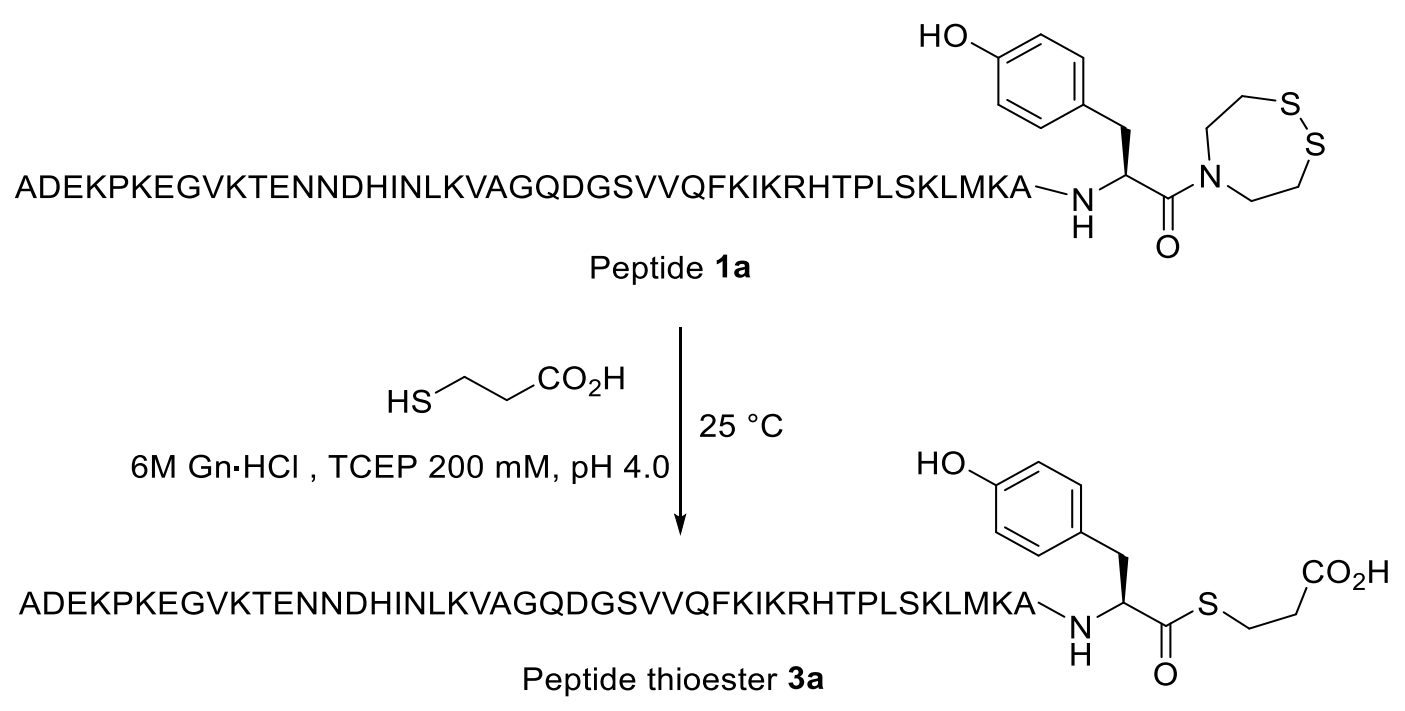

The reaction was carried out under nitrogen atmosphere. TCEP $(29.7 \mathrm{mg}, 0.103 \mu \mathrm{mol})$ was dissolved in $0.1 \mathrm{M}$ pH 7.2 sodium phosphate buffer/6 M Gn·HCl $(1 \mathrm{~mL})$. Peptide $1 \mathrm{a}(18.04 \mathrm{mg}, 2.752 \mu \mathrm{mol})$ was dissolved in the above solution $(0.680 \mathrm{~mL}$ ). Then, 3-mercaptopropionic acid (MPA, $25 \mu \mathrm{L}, 0.29 \mu \mathrm{mol})$ was added and the $\mathrm{pH}$ of the reaction mixture was adjusted to 4.0 by addition of $6 \mathrm{~N} \mathrm{NaOH}$. The reaction was agitated at $25^{\circ} \mathrm{C}$ for $26 \mathrm{~h}$ and then acidified with acetic acid $(60 \mu \mathrm{L})$. The mixture was extracted with diethyl ether $(3 \times 2 \mathrm{~mL})$ to remove the excess of MPA and immediately purified by RP-HPLC using a C18 Xbridge BEH300 prep column (300 $\AA, 10 \times 250 \mathrm{~mm}, 5 \mu \mathrm{m}$ ) to give $10.8 \mathrm{mg}(60 \%)$ of peptide thioester $3 a$.

Gradient used for the HPLC purification: eluent A water containing $0.1 \%$ of TFA, eluent $\mathrm{B} \mathrm{CH}_{3} \mathrm{CN} /$ water : $4 / 1$ by vol containing $0.1 \%$ of TFA, gradient: $0-25 \%$ B in $5 \mathrm{~min}$, then $25-35 \%$ B in $40 \mathrm{~min}$, flow rate $6 \mathrm{~mL} / \mathrm{min}, 50$ ${ }^{\circ} \mathrm{C}$, UV detection at $215 \mathrm{~nm}$. 

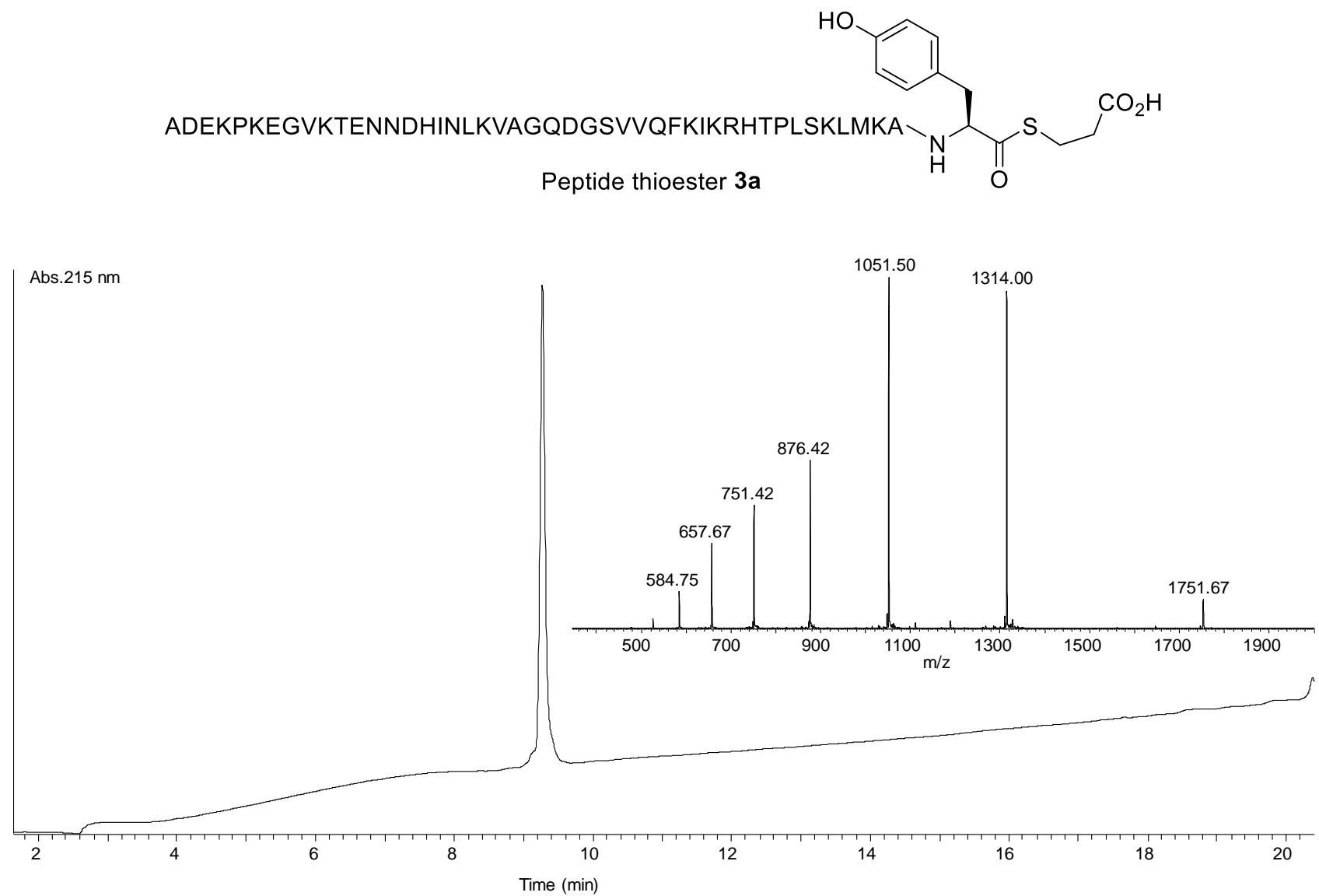

Figure S 6. Analysis of peptide 3a. UPLC-MS analysis ACQUITY UPLC peptide BEH C18 $300 \AA 1.7 \mu \mathrm{m} 2.1 \mathrm{~mm} \times$ $150 \mathrm{~mm}, 50^{\circ} \mathrm{C}$. Flow $0.400 \mathrm{~mL} / \mathrm{min}$, eluent $A 0.1 \%$ trifluoroacetic acid in water, eluent $B 0.1 \%$ trifluoroacetic acid in $100 \%$ acetonitrile. Gradient from $0 \%$ eluent B to $70 \%$ eluent B in 20 min. HPLC trace (UV detection) and MS trace. Calculated for M (average mass) 5252.07, observed 5252.25 after deconvolution.

\section{2) Synthesis and characterization of peptide $3 b$}

Scheme S 3. SEA-thiol exchange reaction for the preparation of peptide thioester $3 \mathrm{~b}$.

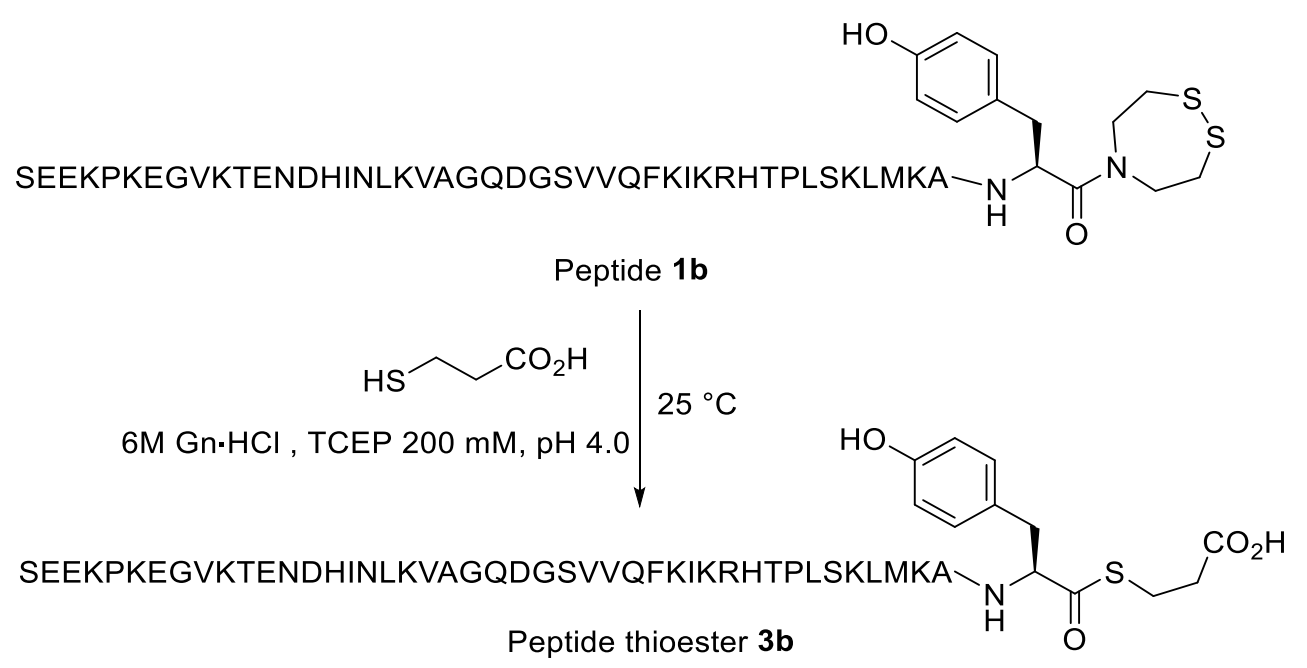


The reaction was carried out under nitrogen atmosphere. TCEP $(29.7 \mathrm{mg}, 0.103 \mu \mathrm{mol})$ was dissolved in $0.1 \mathrm{M}$ pH 7.2 sodium phosphate buffer/6 M Gn·HCl. Peptide $\mathbf{1 b}(11.09 \mathrm{mg}, 1.692 \mu \mathrm{mol})$ was dissolved in the above solution $(0.420 \mathrm{~mL}$ ). Then, 3-mercaptopropionic acid (MPA, $42 \mu \mathrm{L}, 0.48 \mu \mathrm{mol}$ ) was added and the $\mathrm{pH}$ of the reaction mixture was adjusted to 4.0 by addition of $6 \mathrm{M} \mathrm{NaOH}$. The reaction was agitated at $25^{\circ} \mathrm{C}$ for $26 \mathrm{~h}$ and then acidified with acetic acid $(42 \mu \mathrm{L})$. The mixture was extracted with diethyl ether $(3 \times 2 \mathrm{~mL})$ to remove the excess of MPA and immediately purified by RP-HPLC using a C18 Xbridge BEH300 prep column (300 A, $10 \times 250 \mathrm{~mm}, 5 \mu \mathrm{m})$ to give $7.10 \mathrm{mg}(65 \%)$ of peptide thioester $\mathbf{3 b}$.

Gradient used for the HPLC purification: eluent $A$ water containing $0.1 \%$ of TFA, eluent $B \mathrm{CH}_{3} \mathrm{CN} /$ water : $4 / 1$ by vol containing $0.1 \%$ of TFA, gradient: $0-25 \%$ B in $5 \mathrm{~min}$, then $25-35 \%$ B in $40 \mathrm{~min}$, flow rate $6 \mathrm{~mL} / \mathrm{min}, 50$ ${ }^{\circ} \mathrm{C}$, UV detection at $215 \mathrm{~nm}$.

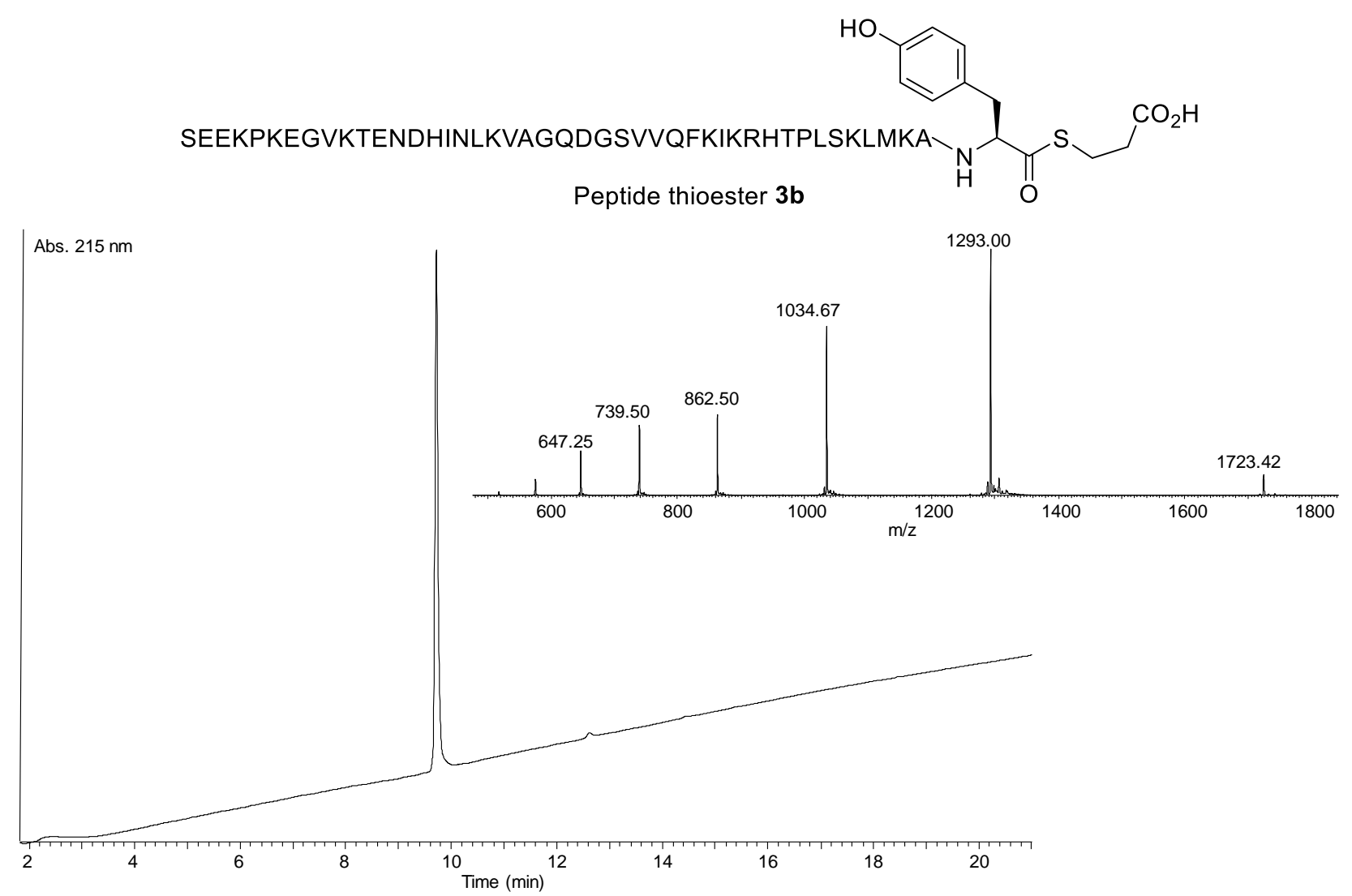

Figure S 7. Analysis of peptide 3b. UPLC-MS analysis ACQUITY UPLC peptide BEH C18 $300 \AA 1.7 \mu \mathrm{m} 2.1 \mathrm{~mm} \times$ $150 \mathrm{~mm}, 50{ }^{\circ} \mathrm{C}$. Flow $0.400 \mathrm{~mL} / \mathrm{min}$, eluent $A 0.1 \%$ trifluoroacetic acid in water, eluent $B 0.1 \%$ trifluoroacetic acid in $100 \%$ acetonitrile. Gradient from $0 \%$ eluent B to $70 \%$ eluent B in 20 min. HPLC trace (UV detection) and MS trace. Calculated for M (average mass) 5167.99, observed 5168.18 after deconvolution. 


\section{Protein synthesis}

\section{A. Chemical synthesis of SUMO-2, SUPO-3 and SUMO-2/3 core proteins}

These proteins are produced by SEA-mediated ligation of peptide segments 1a-c with peptide $\mathbf{2}$.

\section{1) Synthesis and characterization of SUMO-2}

To a solution of TCEP.HCl (31.64 mg, $110.0 \mu \mathrm{mol}, 200 \mathrm{mM}$ final concentration) in $\mathrm{pH} 7.2$ sodium phosphate buffer/ $6 \mathrm{M} \mathrm{Gn} \cdot \mathrm{HCl}(200 \mu \mathrm{L})$ was added MPAA (13.42 mg, $79.77 \mu \mathrm{mol}, 200 \mathrm{mM}$ final concentration) dissolved in the same buffer $(500 \mu \mathrm{L})$. The pH of the mixture was then adjusted to 5.5 with $6 \mathrm{~N} \mathrm{NaOH}$.

SEA peptide $1 \mathrm{a}$ ( $2.23 \mathrm{mg}, 0.335 \mu \mathrm{mol}, 5 \mathrm{mM}$ ) and Cys peptide 2 ( $1.98 \mathrm{mg}, 0.335 \mu \mathrm{mol}, 5 \mathrm{mM}, 1$ equiv) were dissolved in the above solution $(67 \mu \mathrm{L})$ and the reaction mixture was stirred at $25^{\circ} \mathrm{C}$ under nitrogen atmosphere. The reaction was agitated for $33 \mathrm{~h}$.

The progress of the reaction was monitored by HPLC. For each point, a $2 \mu \mathrm{L}$ aliquot was taken from the reaction mixture and quenched by adding $100 \mu \mathrm{L}$ of $10 \%$ acetic acid. The sample was then extracted with $\mathrm{Et}_{2} \mathrm{O}$ to remove MPAA prior to HPLC analysis.

Gradient used for the HPLC purification: eluent A water containing $0.1 \%$ of TFA, eluent $\mathrm{B} \mathrm{CH}_{3} \mathrm{CN} /$ water : $4 / 1$ by vol containing $0.1 \%$ of TFA, gradient: $0-20 \%$ B in $5 \mathrm{~min}$, then $20-40 \%$ B in $60 \mathrm{~min}$, flow rate $6 \mathrm{~mL} / \mathrm{min}, 50$ ${ }^{\circ} \mathrm{C}$, UV detection at $215 \mathrm{~nm}$.

The purification yielded $1.85 \mathrm{mg}$ (83\% yield) of SUMO- 2 . 


\section{SUMO-2: ADEKPKEGVKTENNDHINLKVAGQDGSVVQFKIKRHTPLSKLMKAYCERQGLSMRQIRF RFDGQPINETDTPAQLEMEDEDTIDVFQQQTGG}

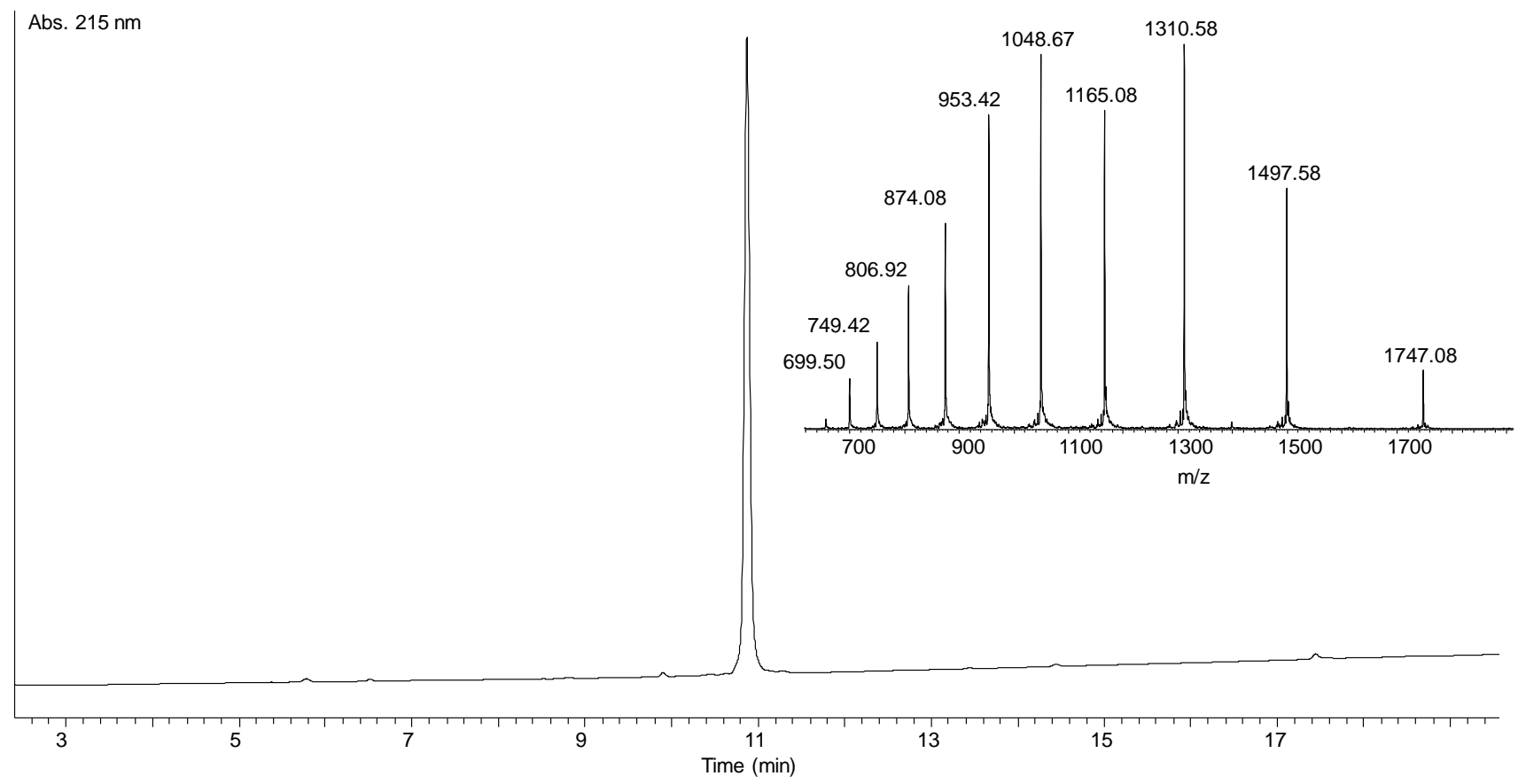

Figure S 8. Analysis of SUMO-2 (2-93) protein. UPLC-MS analysis ACQUITY UPLC peptide BEH C18 $300 \AA 1.7$ $\mu \mathrm{m} 2.1 \mathrm{~mm} \times 150 \mathrm{~mm}, 50^{\circ} \mathrm{C}$. Flow $0.400 \mathrm{~mL} / \mathrm{min}$, eluent $A 0.1 \%$ trifluoroacetic acid in water, eluent $B 0.1 \%$ trifluoroacetic acid in 100\% acetonitrile. Gradient from 0\% eluent B to $70 \%$ eluent B in $20 \mathrm{~min}$. HPLC trace (UV detection) and MS trace. Calculated for M (average mass) 10477.24, observed 10476.71 after deconvolution.

\section{2) Synthesis and characterization of SUMO-3}

To a solution of TCEP.HCl $(31.6 \mathrm{mg}, 110 \mu \mathrm{mol}, 200 \mathrm{mM}$ final concentration) in pH 7.2 sodium phosphate buffer $/ 6 \mathrm{M} \mathrm{Gn} \cdot \mathrm{HCl}(200 \mu \mathrm{L})$ was added MPAA $(13.42 \mathrm{mg}, 79.77 \mu \mathrm{mol}, 200 \mathrm{mM}$ final concentration) dissolved in the same buffer $(500 \mu \mathrm{L})$. The $\mathrm{pH}$ of the mixture was then adjusted to 5.5 with $6 \mathrm{~N} \mathrm{NaOH}$.

The SEA peptide $\mathbf{1 b}(5.38 \mathrm{mg}, 0.825 \mu \mathrm{mol}, 4 \mathrm{mM})$ and Cys peptide $\mathbf{2}(4.94 \mathrm{mg}, 0.825 \mu \mathrm{mol}, 4 \mathrm{mM}, 1.0$ equiv) were dissolved in the above solution $(206 \mu \mathrm{L})$ and the reaction mixture was stirred at $25^{\circ} \mathrm{C}$ under nitrogen atmosphere. The reaction was agitated for $33 \mathrm{~h}$.

The progress of the reaction was monitored by HPLC. For each point, a $2 \mu \mathrm{L}$ aliquot was taken from the reaction mixture and quenched by adding $100 \mu \mathrm{L}$ of $10 \%$ acetic acid. The sample was then extracted with $\mathrm{Et}_{2} \mathrm{O}$ to remove MPAA prior to HPLC analysis.

Gradient used for the HPLC purification: eluent $A$ water containing $0.1 \%$ of TFA, eluent $\mathrm{B} \mathrm{CH}_{3} \mathrm{CN} /$ water : $4 / 1$ by vol containing $0.1 \%$ of TFA, gradient: $0-20 \% \mathrm{~B}$ in $5 \mathrm{~min}$, then $20-40 \% \mathrm{~B}$ in $60 \mathrm{~min}$, flow rate $6 \mathrm{~mL} / \mathrm{min}, 50^{\circ} \mathrm{C}$, UV detection at $215 \mathrm{~nm}$.

The purification yielded $4.20 \mathrm{mg}$ (78\% yield) of SUMO-3. 


\section{SUMO-3: SEEKPKEGVKTENDHINLKVAGQDGSVVQFKIKRHTPLSKLMKAYCERQGLSMRQIRFR FDGQPINETDTPAQLEMEDEDTIDVFQQQTGG}

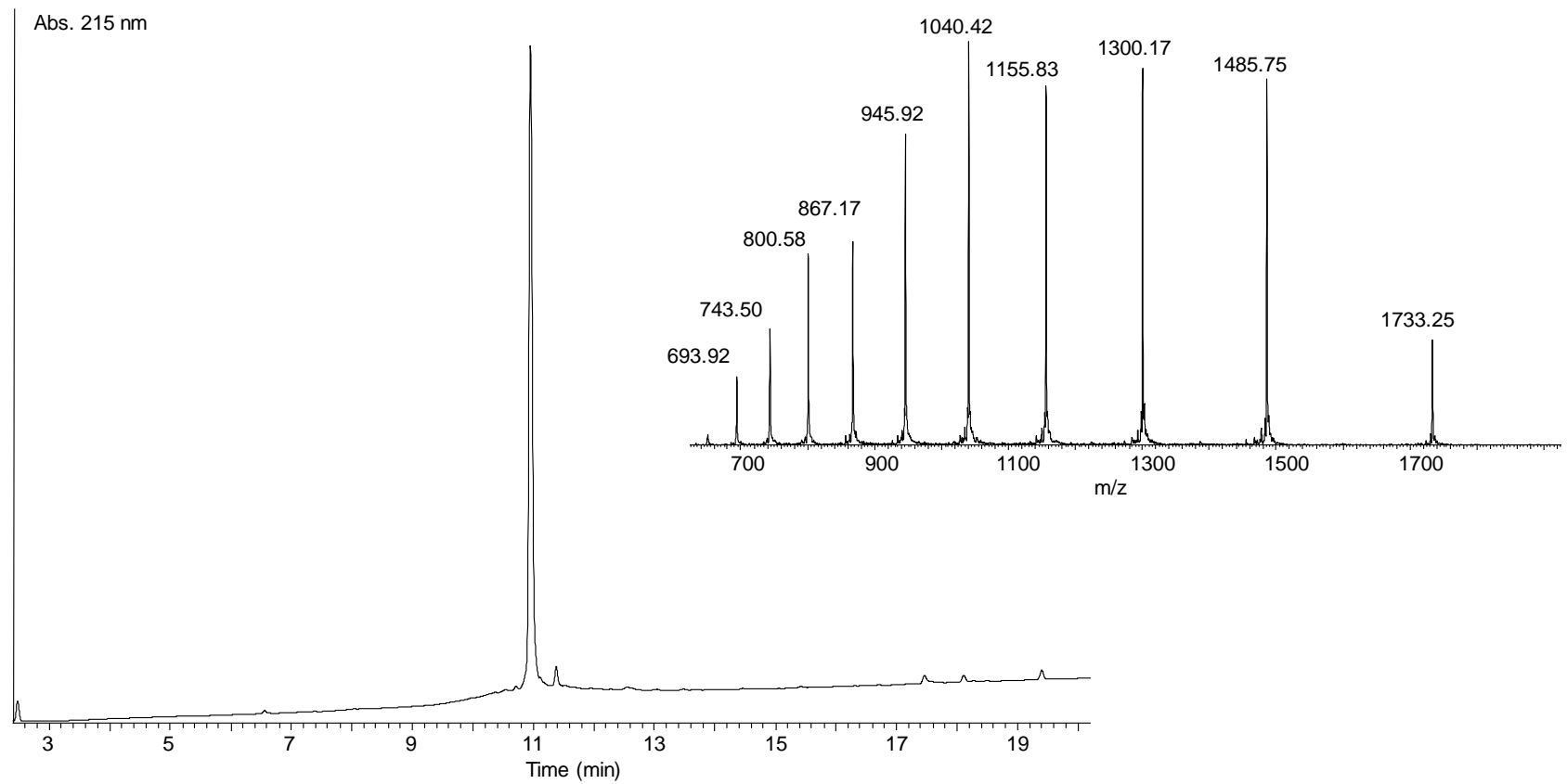

Figure S 9. Analysis of SUMO-3 (2-92) protein. UPLC-MS analysis ACQUITY UPLC peptide BEH C18 $300 \AA 1.7$ $\mu \mathrm{m} 2.1 \mathrm{~mm} \times 150 \mathrm{~mm}, 50{ }^{\circ} \mathrm{C}$. Flow $0.400 \mathrm{~mL} / \mathrm{min}$, eluent A $0.1 \%$ trifluoroacetic acid in water, eluent $B 0.1 \%$ trifluoroacetic acid in 100\% acetonitrile. Gradient from 0\% eluent B to $70 \%$ eluent B in 20 min. HPLC trace (UV detection) and MS trace. Calculated for M (average mass) 10393.66, observed 10393.84 after deconvolution.

\section{3) Synthesis and characterization of SUMO-2/3 core}

To a solution of TCEP. $\mathrm{HCl}(31.6 \mathrm{mg}, 110 \mu \mathrm{mol}, 200 \mathrm{mM}$ final concentration) in $\mathrm{pH} 7.2$ sodium phosphate buffer/ $6 \mathrm{M} \mathrm{Gn} \cdot \mathrm{HCl}(200 \mu \mathrm{L})$ was added MPAA $(13.4 \mathrm{mg}, 79.8 \mu \mathrm{mol}, 200 \mathrm{mM}$ final concentration) dissolved in the same buffer $(500 \mu \mathrm{L})$. The $\mathrm{pH}$ of the mixture was then adjusted to 7.2 with $6 \mathrm{~N} \mathrm{NaOH}$.

The SEA peptide 1c (5.95 mg, $1.25 \mu \mathrm{mol}, 4 \mathrm{mM}$ ) and Cys peptide 2 (7.23 mg, $1.25 \mu \mathrm{mol}, 4 \mathrm{mM}, 1.0$ equiv) were dissolved in the above solution $(313 \mu \mathrm{L})$ and the reaction mixture was stirred at $25^{\circ} \mathrm{C}$ under nitrogen atmosphere. The reaction was agitated for $35 \mathrm{~h}$.

The progress of the reaction was monitored by HPLC. For each point, a $2 \mu \mathrm{L}$ aliquot was taken from the reaction mixture and quenched by adding $100 \mu \mathrm{L}$ of $10 \%$ acetic acid. The sample was then extracted with $\mathrm{Et}_{2} \mathrm{O}$ to remove MPAA prior to HPLC analysis.

Gradient used for the HPLC purification: eluent A water containing $0.1 \%$ of TFA, eluent $\mathrm{B} \mathrm{CH}_{3} \mathrm{CN} /$ water : $4 / 1$ by vol containing $0.1 \%$ of TFA, gradient: $0-20 \% \mathrm{~B}$ in $5 \mathrm{~min}$, then $20-40 \% \mathrm{~B}$ in $60 \mathrm{~min}$, flow rate $6 \mathrm{~mL} / \mathrm{min}, 50^{\circ} \mathrm{C}$, UV detection at $215 \mathrm{~nm}$.

The purification yielded $3.57 \mathrm{mg}$ (60\% yield) of SUMO-2/3 core. 


\section{SUMO-2/3 core: DHINLKVAGQDGSVVQFKIKRHTPLSKLMKAYCERQGLSMRQIRFR FDGQPINETDTPAQLEMEDEDTIDVFQQQTGG}

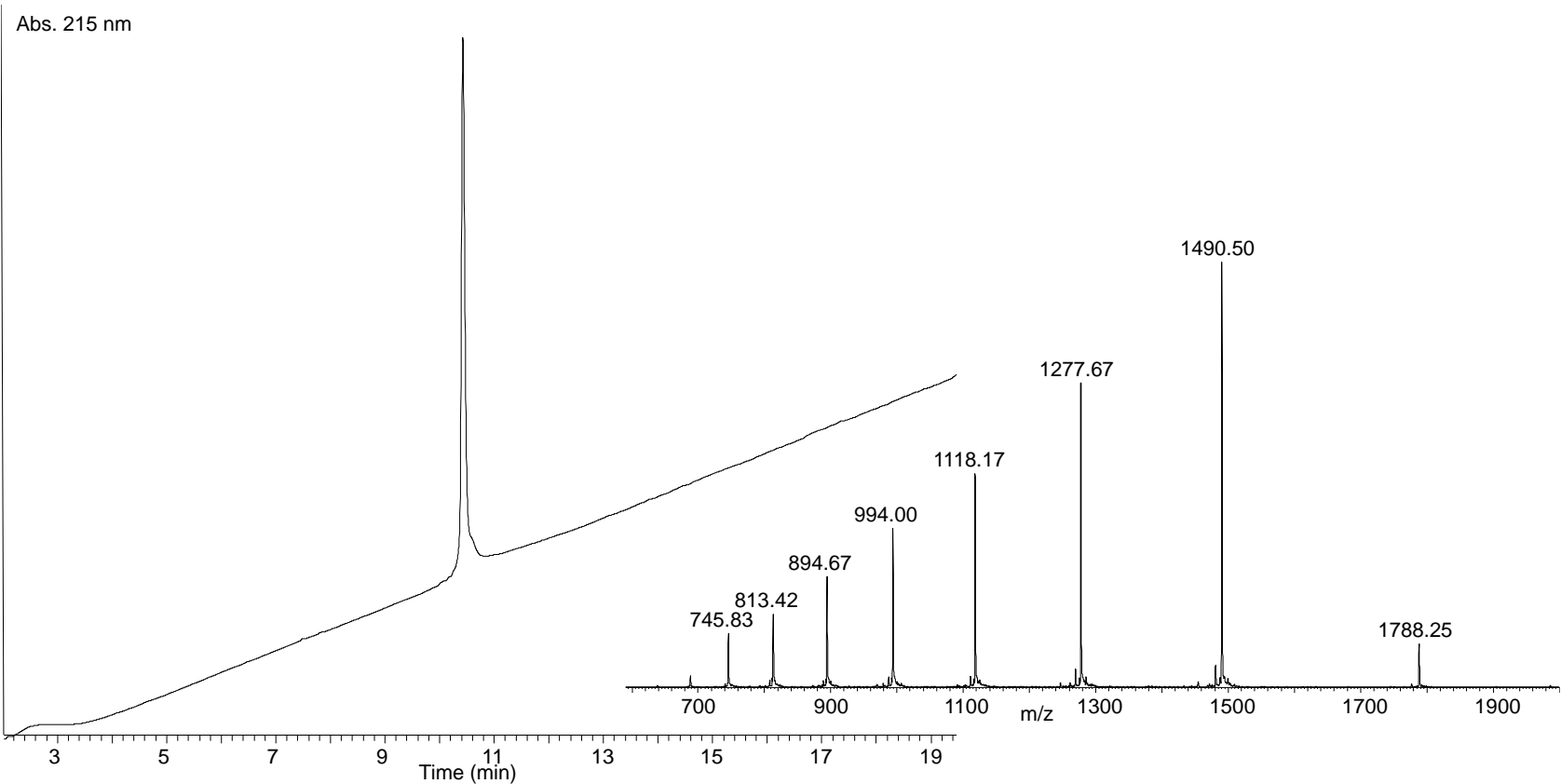

Figure S 10. Analysis of SUMO-2/3 core. UPLC-MS analysis ACQUITY UPLC peptide BEH C18 $300 \AA 1.7 \mu \mathrm{m} 2.1$ $\mathrm{mm} \times 150 \mathrm{~mm}, 50^{\circ} \mathrm{C}$. Flow $0.400 \mathrm{~mL} / \mathrm{min}$, eluent $A 0.1 \%$ trifluoroacetic acid in water, eluent $B 0.1 \%$ trifluoroacetic acid in $100 \%$ acetonitrile. Gradient from $0 \%$ eluent B to $70 \%$ eluent B in 20 min. HPLC trace (UV detection) and MS trace. Calculated for M (average mass) 8936.85, observed 8937.03 after deconvolution.

\section{B. Desulfurization of SUMO proteins}

\section{1) Synthesis and characterization of SUMO-2 C48A}

SUMO-2 (2.25 mg, $0.214 \mu \mathrm{mol}, 0.100 \mathrm{mM}$ final concentration) was dissolved in a solution of TCEP (57.3 $\mathrm{mg} / \mathrm{mL}, 200 \mathrm{mM}$ final concentration), 2,2'-azobis[2-(2-imidazolin-2-yl)propane]di-hydrochloride (VA-044, 6.5 $\mathrm{mg} / \mathrm{mL}, 20 \mathrm{mM}$ final concentration) and reduced glutathione (GSH, $15.4 \mathrm{mg} / \mathrm{mL}, 50.0 \mathrm{mM}$ final concentration) in $0.1 \mathrm{M} \mathrm{pH} 7.2$ ammonium phosphate buffer/6 M Gn· HCl (4 mL). The desulfurization was carried out at $25{ }^{\circ} \mathrm{C}$ and monitored by MALDI-TOF mass spectrometry. After $25 \mathrm{~h}$, the reaction product was purified by HPLC.

Gradient used for the HPLC purification: eluent A water containing $0.1 \%$ of TFA, eluent $\mathrm{B} \mathrm{CH}_{3} \mathrm{CN} /$ water : $4 / 1$ by vol containing $0.1 \%$ of TFA, gradient: $0-10 \%$ B in $5 \mathrm{~min}$, then $10-100 \% \mathrm{~B}$ in $15 \mathrm{~min}$, flow rate $6 \mathrm{~mL} / \mathrm{min}$, $50^{\circ} \mathrm{C}$, UV detection at $215 \mathrm{~nm}$.

The purification yielded $1.17 \mathrm{mg}$ (52\% yield) of SUMO-2 C48A. 


\section{SUMO-2 C48A: ADEKPKEGVKTENNDHINLKVAGQDGSVVQFKIKRHTPLSKLMKAYAERQGLSMRQIRF RFDGQPINETDTPAQLEMEDEDTIDVFQQQTGG}

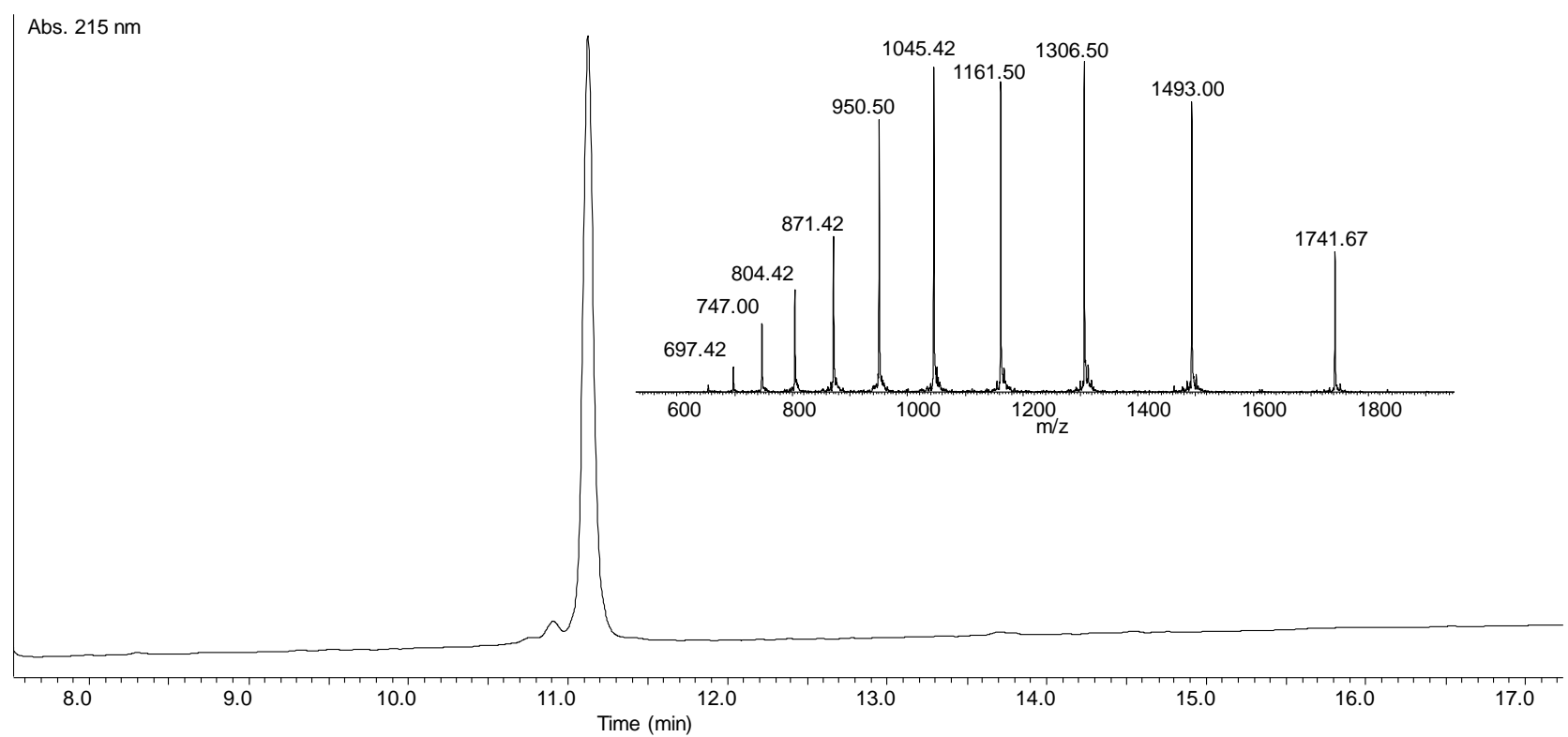

Figure S 11. Analysis of SUMO-2 C48A protein. UPLC-MS analysis ACQUITY UPLC peptide BEH C18 $300 \AA 1.7$ $\mu \mathrm{m} 2.1 \mathrm{~mm} \times 150 \mathrm{~mm}, 50^{\circ} \mathrm{C}$. Flow $0.400 \mathrm{~mL} / \mathrm{min}$, eluent $A 0.1 \%$ trifluoroacetic acid in water, eluent $B 0.1 \%$ trifluoroacetic acid in 100\% acetonitrile. Gradient from 0\% eluent B to $70 \%$ eluent B in $20 \mathrm{~min}$. HPLC trace (UV detection) and MS trace. Calculated for M (average mass) 10445.68, observed 10444.25 after deconvolution.

\section{2) Synthesis and characterization of SUMO-3 C47A protein}

SUMO-3 $(3.00 \mathrm{mg}, 0.300 \mu \mathrm{mol}, 0.100 \mathrm{mM}$ final concentration) was dissolved in a solution of TCEP (57.3 $\mathrm{mg} / \mathrm{mL}, 200 \mathrm{mM}$ final concentration), 2,2'-azobis[2-(2-imidazolin-2-yl)propane]dihydrochloride (VA-044, 6.5 $\mathrm{mg} / \mathrm{mL}, 20 \mathrm{mM}$ final concentration) and reduced glutathione $(\mathrm{GSH}, 15.4 \mathrm{mg} / \mathrm{mL}, 50.0 \mathrm{mM}$ final concentration) in $0.1 \mathrm{M} \mathrm{pH} 7.2$ ammonium phosphate buffer/ $6 \mathrm{M} \mathrm{Gn} \cdot \mathrm{HCl}(4 \mathrm{~mL})$. The desulfurization was carried out at $25^{\circ} \mathrm{C}$ and monitored by MALDI-TOF mass spectrometry. After $24 \mathrm{~h}$, the reaction product was purified by HPLC.

Gradient used for the HPLC purification: eluent A water containing $0.1 \%$ of TFA, eluent $\mathrm{B} \mathrm{CH}_{3} \mathrm{CN} /$ water : $4 / 1$ by vol containing $0.1 \%$ of TFA, gradient: $0-10 \%$ B in $5 \mathrm{~min}$, then $10-100 \%$ B in $15 \mathrm{~min}$, flow rate $6 \mathrm{~mL} / \mathrm{min}$, $50^{\circ} \mathrm{C}$, UV detection at $215 \mathrm{~nm}$

The purification yielded $1.47 \mathrm{mg}$ (49\% yield) of SUMO-3 C47A. 


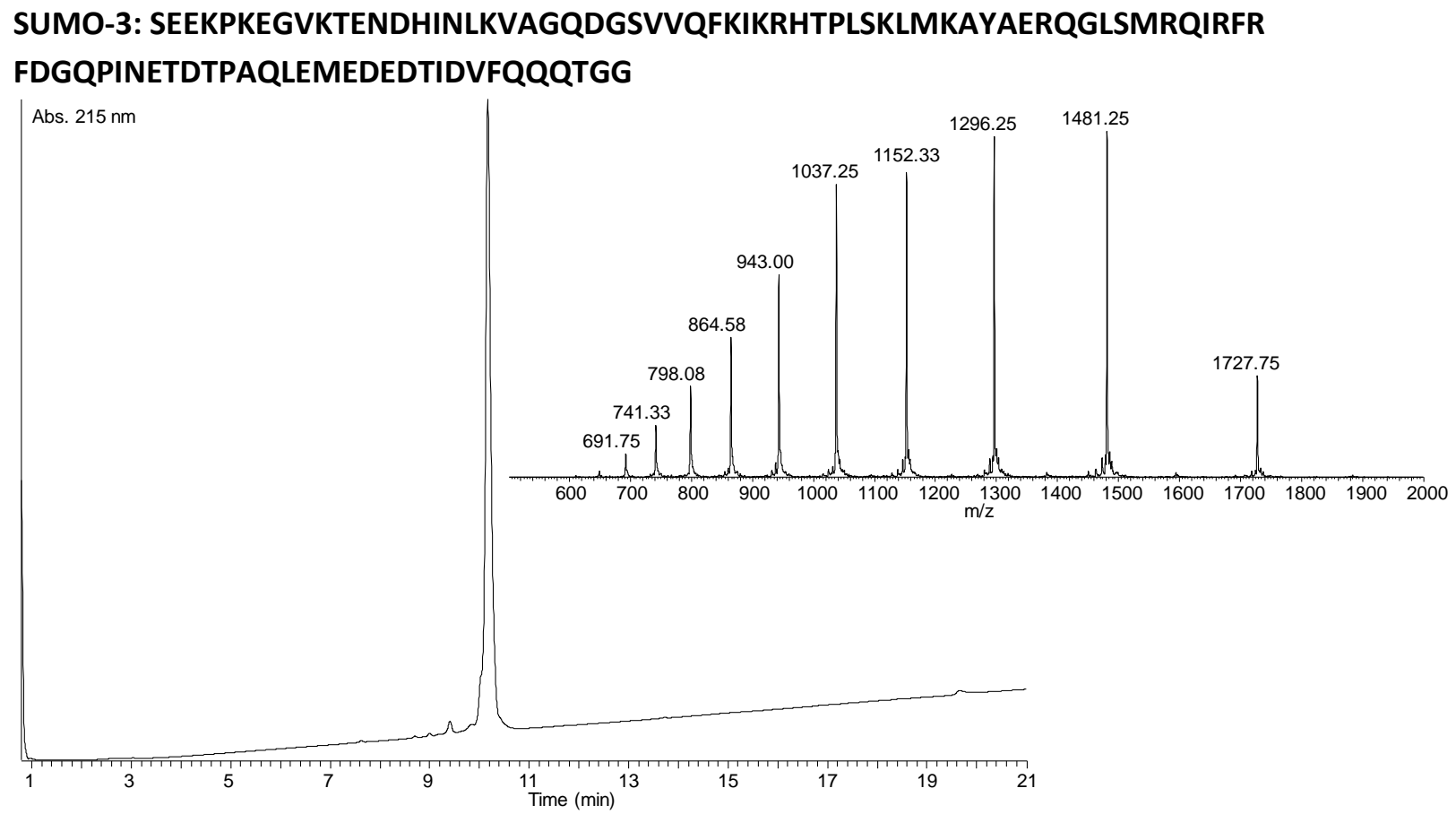

Figure S 12. Analysis of SUMO-3 C47A protein. UPLC-MS analysis ACQUITY UPLC peptide BEH C18 $300 \AA 1.7$ $\mu \mathrm{m} 2.1 \mathrm{~mm} \times 150 \mathrm{~mm}, 50{ }^{\circ} \mathrm{C}$. Flow $0.400 \mathrm{~mL} / \mathrm{min}$, eluent A $0.1 \%$ trifluoroacetic acid in water, eluent $B 0.1 \%$ trifluoroacetic acid in 100\% acetonitrile. Gradient from $0 \%$ eluent B to $70 \%$ eluent B in $20 \mathrm{~min}$. HPLC trace (UV detection) and MS trace. Calculated for M (average mass) 10361.60, observed 10360.67 after deconvolution.

\section{3) Synthesis and characterization of SUMO-2/3 core C48A protein}

SUMO-2/3 core $(3.00 \mathrm{mg}, 0.336 \mu \mathrm{mol}, 0.100 \mathrm{mM}$ final concentration) was dissolved in a solution of TCEP (57.3 mg/mL, $200 \mathrm{mM}$ final concentration), 2,2'-azobis[2-(2-imidazolin-2-yl)propane]dihydrochloride (VA$044,6.50 \mathrm{mg} / \mathrm{mL}, 20 \mathrm{mM}$ final concentration) and reduced glutathione $(15.4 \mathrm{mg} / \mathrm{mL}, 50.0 \mathrm{mM}$ final concentration) in $0.1 \mathrm{M} \mathrm{pH} 7.2$ ammonium phosphate buffer/6 M Gn. $\mathrm{HCl}(4 \mathrm{~mL})$,. The desulfurization was carried out at $25^{\circ} \mathrm{C}$ and monitored by MALDI-TOF mass spectrometry. After $24 \mathrm{~h}$, the reaction product was purified by HPLC.

Gradient used for the HPLC purification: eluent $A$ water containing $0.1 \%$ of TFA, eluent $B \mathrm{CH}_{3} \mathrm{CN} /$ water : $4 / 1$ by vol containing $0.1 \%$ of TFA, gradient: $0-10 \% \mathrm{~B}$ in $5 \mathrm{~min}$, then $10-100 \% \mathrm{~B}$ in $15 \mathrm{~min}$, flow rate $6 \mathrm{~mL} / \mathrm{min}$, $50^{\circ} \mathrm{C}$, UV detection at $215 \mathrm{~nm}$.

The purification yielded $1.35 \mathrm{mg}$ (45\% yield) of SUMO-2/3 C48A. 


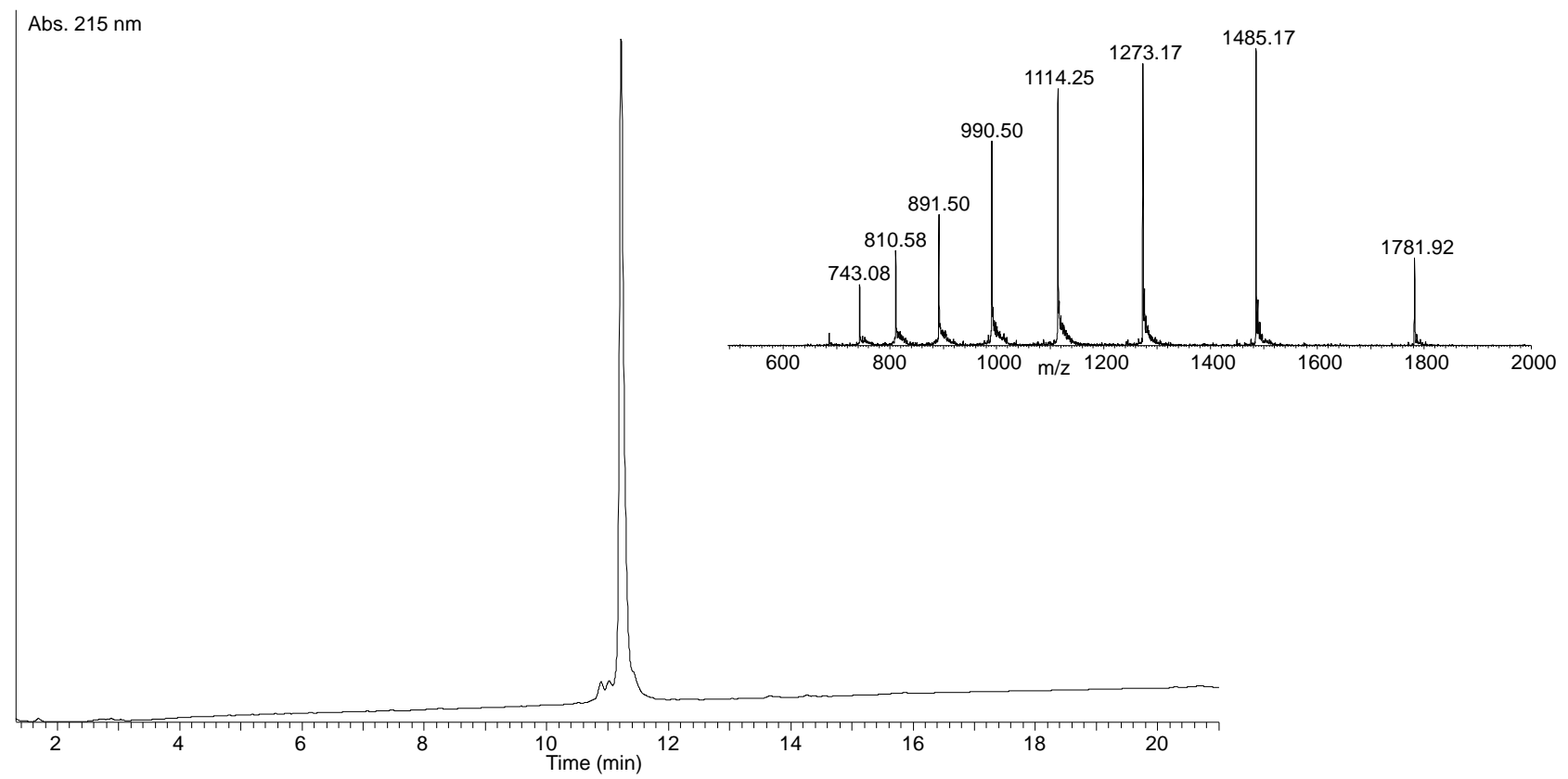

Figure S 13. Analysis of SUMO-2/3 core C48A. UPLC-MS analysis ACQUITY UPLC peptide BEH C18 $300 \AA$ A 1.7 $\mu \mathrm{m} 2.1 \mathrm{~mm} \times 150 \mathrm{~mm}, 50{ }^{\circ} \mathrm{C}$. Flow $0.400 \mathrm{~mL} / \mathrm{min}$, eluent A $0.1 \%$ trifluoroacetic acid in water, eluent $B 0.1 \%$ trifluoroacetic acid in 100\% acetonitrile. Gradient from 0\% eluent B to 70\% eluent B in 20 min. HPLC trace (UV detection) and MS trace. Calculated for M (average mass) 8905.11, observed 8905.07 after deconvolution.

\section{Chemical synthesis of SUMO-2/3 conjugates}

\section{1) Synthesis and characterization of peptide 6}

Peptide 6 was synthesized using standard Fmoc-SPPS protocols $(0.10 \mathrm{mmol}$, Novasyn TGR resin, 0.25 $\mathrm{mmol} / \mathrm{g}$ ). The amino acids (10 equiv) were activated using HATU ( 9.5 equiv)/DIEA (20 equiv) in DMF. Each amino acid was coupled twice. The peptidyl resin was acetylated with $\mathrm{Ac}_{2} \mathrm{O} / \mathrm{DIEA}$ in DMF after each double coupling. For proteinogenic amino acids the peptide synthesis was performed using an automated column peptide synthesizer.

Fmoc-Lys[Boc-Cys(Trt)]-OH derivative was coupled manually: Fmoc-Lys[Boc-Cys(Trt)]-OH (97.7 mg, 120 umol, 1.20 equiv) was activated using HATU ( $41.8 \mathrm{mg}, 110 \mu \mathrm{mol}, 1.14$ equiv)/DIEA ( $41.8 \mu \mathrm{L}, 240 \mu \mathrm{mol}, 2.40$ equiv) in DMF (1 mL) during $1 \mathrm{~min}$ and then added to the peptidyl resin. The resin was agitated for $1 \mathrm{~h} 30$ and then washed with DMF ( $3 \times 2 \mathrm{~min})$. After the peptide elongation step, the resin was washed with DMF $(3 \times 2 \mathrm{~min})$, $\mathrm{CH}_{2} \mathrm{Cl}_{2}(3 \times 2 \mathrm{~min})$, diethyl ether $(2 \times 2 \mathrm{~min})$ and dried in vacuo.

The peptidyl resin was finally deprotected and cleaved in TFA/TIS/EDT/ $\mathrm{H}_{2} \mathrm{O}: 92.5 / 2.5 / 2.5 / 2.5$ by vol (10 mL) for $1 \mathrm{~h} 30$. The crude peptide was precipitated in ice-cold heptane /diethyl ether : 1/1 by vol, solubilized in deionized water and lyophilized to yield $158 \mathrm{mg}$ ( $66 \%$ crude) of crude peptide. 
Preparative HPLC conditions for peptide 6: XBridge BEH300 C18 $(5 \mu \mathrm{m}, 300 \AA, 10 \times 250 \mathrm{~mm})$ column, eluent A water containing $0.1 \%$ of TFA, eluent $B \mathrm{CH}_{3} \mathrm{CN} /$ water : $4 / 1$ by vol containing $0.1 \%$ of TFA, gradient: $0-5 \% \mathrm{~B}$ in $5 \mathrm{~min}, 5-20 \% \mathrm{~B}$ in $30 \mathrm{~min}$, flow rate $6 \mathrm{~mL} / \mathrm{min}, 50{ }^{\circ} \mathrm{C}$, UV detection at $215 \mathrm{~nm}$.
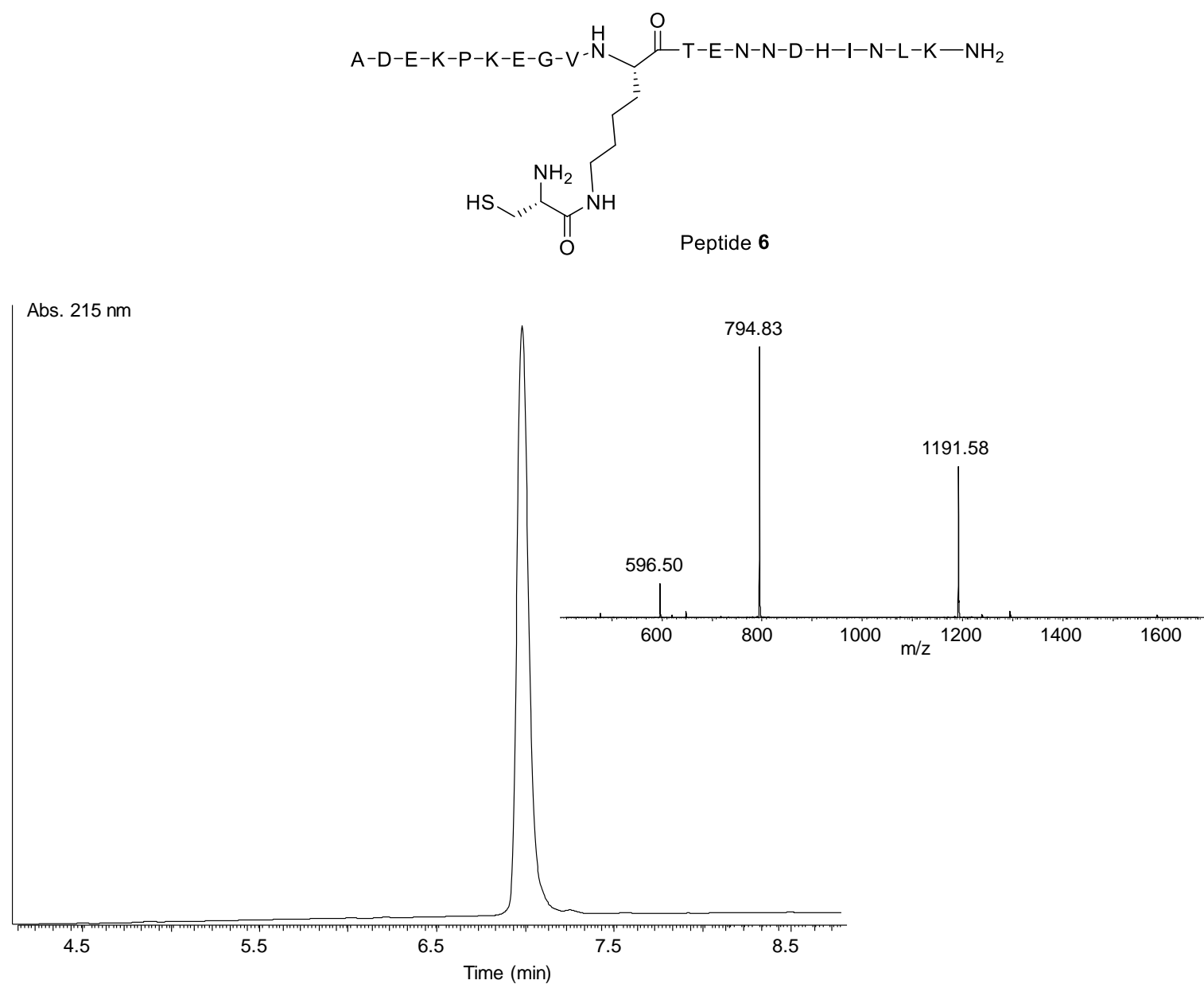

Figure S 14. Analysis of target peptide 6. UPLC-MS analysis ACQUITY UPLC peptide BEH C18 $300 \AA 1.7 \mu \mathrm{m}$ $2.1 \mathrm{~mm} \times 150 \mathrm{~mm}, 50^{\circ} \mathrm{C}$. Flow $0.400 \mathrm{~mL} / \mathrm{min}$, eluent $A 0.1 \%$ trifluoroacetic acid in water, eluent $B 0.1 \%$ trifluoroacetic acid in $100 \%$ acetonitrile. Gradient from $0 \%$ eluent B to $70 \%$ eluent B in 20 min. HPLC trace (UV detection) and MS trace. Calculated for M (average mass) 2381.65, observed 2381.33 after deconvolution.

\section{2) Synthesis and characterization of SUMO-2 conjugate 7a}

The whole process was carried under nitrogen atmosphere.

First ligation step (NCL):

A solution of MPAA ( $26.9 \mathrm{mg}, 0.159 \mathrm{mmol})$ in $6 \mathrm{M} \mathrm{Gn} \cdot \mathrm{HCl} / 0.1 \mathrm{M} \mathrm{pH} 7.2$ sodium phosphate buffer was prepared $(0.800 \mathrm{~mL})$. Peptide thioester $3 \mathrm{a}(2.63 \mathrm{mg}, 0.400 \mu \mathrm{mol})$ and SEA ${ }^{\text {off }}$ peptide segment $4(2.38 \mathrm{mg}, 0.400$ $\mu \mathrm{mol}, 1$ equiv) were dissolved in the above solution $(80 \mu \mathrm{L})$ and the $\mathrm{pH}$ was adjusted to 7.2 by addition of aqueous $6 \mathrm{~N} \mathrm{NaOH}$. The reaction was agitated for $22 \mathrm{~h}$ at $25^{\circ} \mathrm{C}$.

Second ligation step (SEA ligation): 
Then, a solution of TCEP $(24.14 \mathrm{mg}, 84.20 \mu \mathrm{mol})$ and MPAA $(14.16 \mathrm{mg}, 84.20 \mu \mathrm{mol})$ in $6 \mathrm{M} \mathrm{Gn} \cdot \mathrm{HCl} / 0.1 \mathrm{M} \mathrm{pH}$ 7.2 sodium phosphate buffer $(420 \mu \mathrm{L})$ was prepared and $63 \mu \mathrm{L}$ used to dissolve peptide $6(2.89 \mathrm{mg}, 0.946$ $\mu \mathrm{mol}, 15.0 \mathrm{mM}$ ). The $\mathrm{pH}$ of this solution was adjusted to 5.5 by addition of aqueous $6 \mathrm{~N} \mathrm{NaOH}$. The peptide 6 solution was then added to the above reaction mixture and the $\mathrm{pH}$ was adjusted to 5.5 by addition of $6 \mathrm{~N}$ $\mathrm{NaOH}(10 \mu \mathrm{L})$. The final peptide concentration was $4.0 \mathrm{mM}$. The reaction was agitated for $36 \mathrm{~h}$ and then acidified with glacial acetic acid $(14.5 \mu \mathrm{L})$ to reach $10 \%$ by vol. The solution was then extracted with diethyl ether $(3 \times 2 \mathrm{~mL})$ to remove the excess of MPAA. The mixture was immediately purified by HPLC to yield 1.85 $\mathrm{mg}$ (70 \% HPLC purification) of SUMO-2 conjugate $7 a$.

Semi-preparative HPLC conditions: XBridge BEH300 C18 (5 $\mu \mathrm{m}, 300 \AA, 10 \times 250 \mathrm{~mm})$ column, eluent A water containing $0.1 \%$ of TFA, eluent $\mathrm{B} \mathrm{CH} \mathrm{CH}_{3} \mathrm{CN} /$ water : $4 / 1$ by vol containing $0.1 \%$ of TFA, gradient: $0-25 \% \mathrm{~B}$ in 5 $\min , 25-45 \% \mathrm{~B}$ in $60 \mathrm{~min}$, flow rate $6 \mathrm{~mL} / \mathrm{min}, 65^{\circ} \mathrm{C}$, UV detection at $215 \mathrm{~nm}$.

SUMO-2 conjugate 7a: ADEKPK(ADEKPKEGVKTENNDHINLKVAGQDGSVVQFKIKRHTPLSKLMKAYCERQGLSMRQIRFRFDGQPINETDTPAQLEMEDEDTIDVFQQQTGGC)EGVKTENNDHINLK-NH ${ }_{2}$

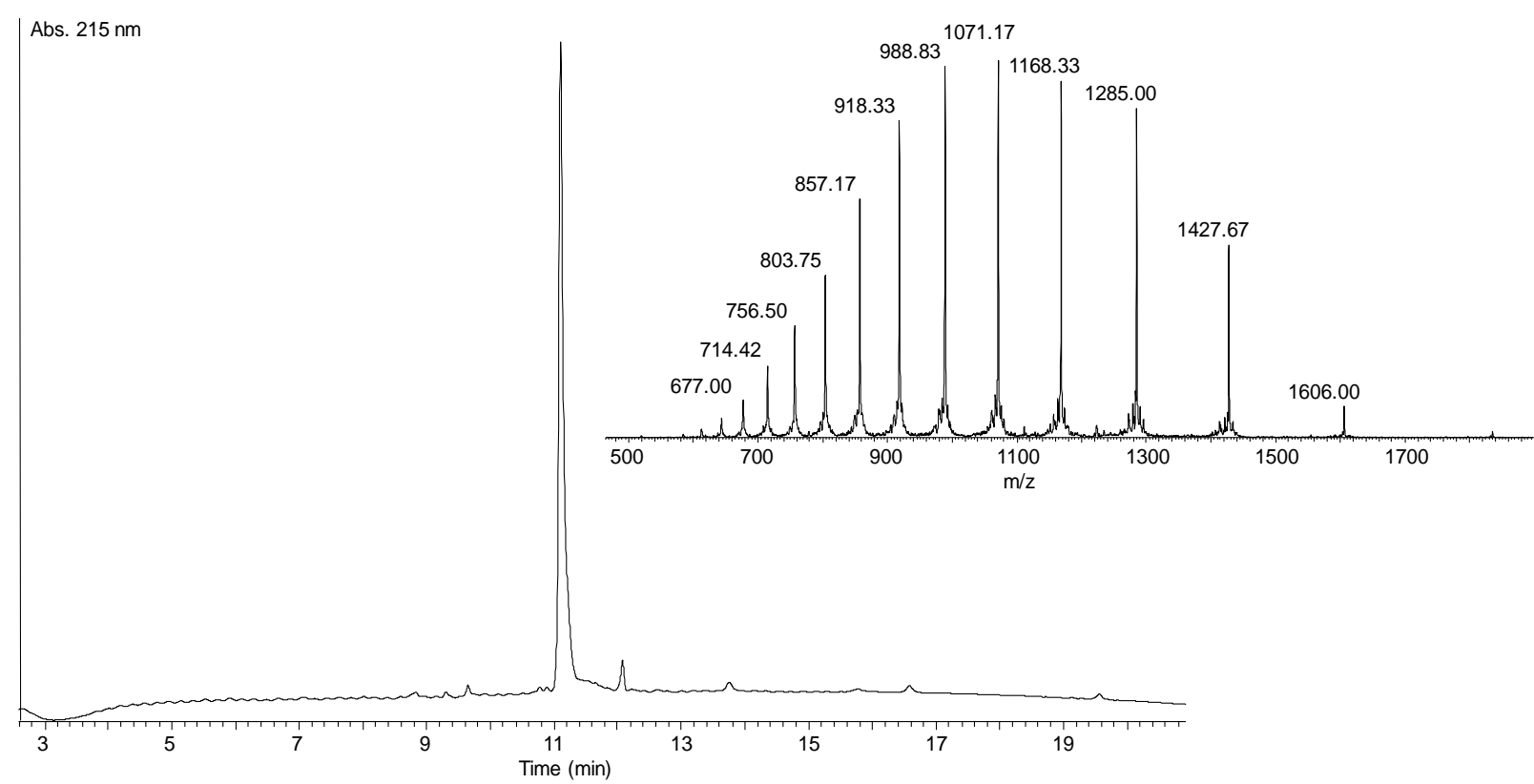

Fig-

ure S 15. Analysis of SUMO-2 conjugate 7a. UPLC-MS analysis ACQUITY UPLC peptide BEH C18 $300 \AA 1.7 \mu \mathrm{m}$ $2.1 \mathrm{~mm} \times 150 \mathrm{~mm}, 50{ }^{\circ} \mathrm{C}$. Flow $0.400 \mathrm{~mL} / \mathrm{min}$, eluent $A 0.1 \%$ trifluoroacetic acid in water, eluent $B 0.1 \%$ trifluoroacetic acid in 100\% acetonitrile. Gradient from 0\% eluent B to $70 \%$ eluent B in 20 min. HPLC trace (UV detection) and MS trace. Calculated for M (average mass) 12841.38, observed 12841.92 after deconvolution.

\section{3) Synthesis and characterization of SUMO-3 conjugate 7b}

The whole process was carried under nitrogen atmosphere.

First ligation step (NCL): 
A solution of MPAA ( $26.9 \mathrm{mg}, 0.159 \mathrm{mmol})$ in $6 \mathrm{M} \mathrm{Gn} \cdot \mathrm{HCl} / 0.1 \mathrm{M} \mathrm{pH} 7.2$ sodium phosphate buffer was prepared $(0.800 \mathrm{~mL})$. Peptide thioester $\mathbf{3 b}(3.30 \mathrm{mg}, 0.506 \mu \mathrm{mol})$ and $\mathrm{SEA}^{\text {off }}$ peptide segment $4(3.03 \mathrm{mg}, 0.506$ $\mu \mathrm{mol})$ were dissolved in the above solution $(101 \mu \mathrm{L})$ and the $\mathrm{pH}$ was adjusted to 7.2 by addition of aqueous $6 \mathrm{~N} \mathrm{NaOH}$. The reaction was agitated for $22 \mathrm{~h}$ at $25^{\circ} \mathrm{C}$.

Second ligation step (SEA ligation):

Then, a solution of TCEP $(24.14 \mathrm{mg}, 84.20 \mu \mathrm{mol})$ and MPAA $(14.16 \mathrm{mg}, 84.20 \mu \mathrm{mol})$ in $6 \mathrm{M} \mathrm{Gn} \cdot \mathrm{HCl} / 0.1 \mathrm{M} \mathrm{pH}$ 7.2 sodium phosphate buffer $(420 \mu \mathrm{L})$ was prepared and $80 \mu \mathrm{L}$ of this solution was used to dissolve peptide $6(3.68 \mathrm{mg}, 1.20 \mu \mathrm{mol}, 15.0 \mathrm{mM})$. The $\mathrm{pH}$ of this solution was adjusted to 5.5 by addition of $6 \mathrm{~N} \mathrm{NaOH}$. The peptide solution was then added to the above reaction mixture and the $\mathrm{pH}$ was adjusted to 5.5 by addition of $6 \mathrm{~N} \mathrm{NaOH}(10 \mu \mathrm{L})$. The final peptide concentration was $4.0 \mathrm{mM}$. The reaction was agitated for $36 \mathrm{~h}$ and then acidified with glacial acetic acid ( $36 \mu \mathrm{L}$ ) to reach $10 \%$ by vol. The mixture was then extracted with diethyl ether $(3 \times 2 \mathrm{~mL})$ to remove the excess of MPAA. The mixture was immediately purified by HPLC to yield 2.40 mg (65 \% HPLC purification) of SUMO-2 conjugate $7 \mathbf{b}$.

Semi-preparative HPLC conditions: XBridge BEH300 C18 (5 $\mu \mathrm{m}, 300 \AA$, $10 \times 250 \mathrm{~mm})$ column, eluent A water containing $0.1 \%$ of TFA, eluent $\mathrm{B} \mathrm{CH} \mathrm{CH}_{3} \mathrm{CN} /$ water : $4 / 1$ by vol containing $0.1 \%$ of TFA, gradient: $0-25 \% \mathrm{~B}$ in 5 $\min , 25-45 \% \mathrm{~B}$ in $60 \mathrm{~min}$, flow rate $6 \mathrm{~mL} / \mathrm{min}, 65^{\circ} \mathrm{C}$, UV detection at $215 \mathrm{~nm}$.

SUMO-3 conjugate 7b: ADEKPK(SEEKPKEGVKTENDHINLKVAGQDGSVVQFKIKRHTPLSKLMKAYCERQGLSMRQIRFRFDGQPINETDTPAQLEMEDEDTIDVFQQQTGGC)EGVKTENNDHINLK-NH ${ }_{2}$

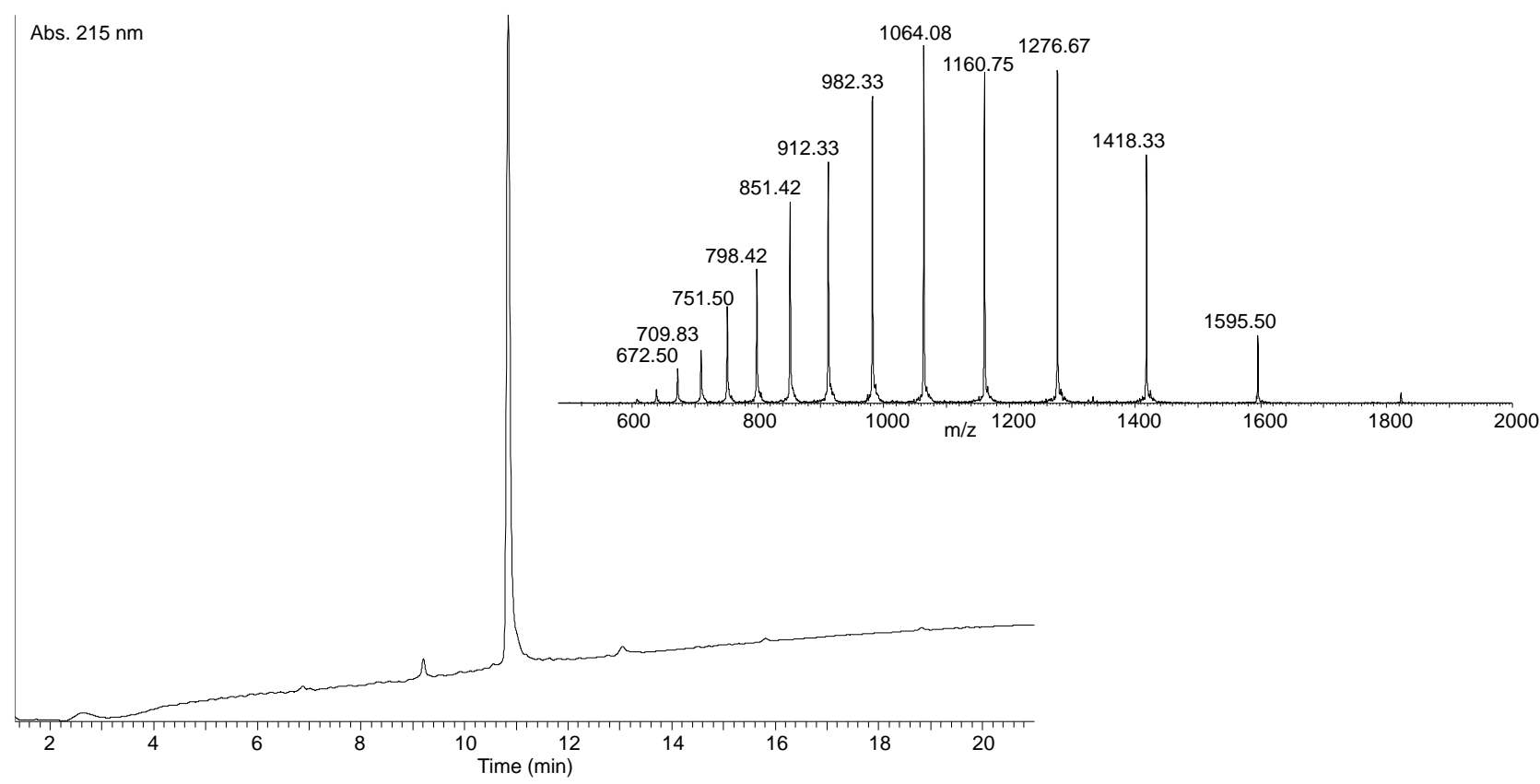

Figure S 16. Analysis of SUMO-3 conjugate 7b. UPLC-MS analysis ACQUITY UPLC peptide BEH C18 $300 \AA$ 1.7 $\mu \mathrm{m} 2.1 \mathrm{~mm} \times 150 \mathrm{~mm}, 50{ }^{\circ} \mathrm{C}$. Flow $0.400 \mathrm{~mL} / \mathrm{min}$, eluent $A 0.1 \%$ trifluoroacetic acid in water, eluent $B 0.1 \%$ trifluoroacetic acid in 100\% acetonitrile. Gradient from 0\% eluent B to 70\% eluent B in 20 min. HPLC trace (UV detection) and MS trace. Calculated for M (average mass) 12757.30, observed 12756.19 after deconvolution. 


\section{Desulfurization of SUMO-2/3 conjugates}

1) Desulfurization of conjugate $7 a$ in native conditions

Conjugate $7 \mathrm{a}(0.61 \mathrm{mg}, 0.46 \mu \mathrm{mol}, 0.10 \mathrm{mM}$ final concentration) was dissolved in a solution of TCEP (57.3 $\mathrm{mg} / \mathrm{mL}, 200 \mathrm{mM}$ final concentration), 2,2'-azobis[2-(2-imidazolin-2-yl)propane]dihydrochloride (VA-044, 6.5 $\mathrm{mg} / \mathrm{mL}, 20 \mathrm{mM}$ final concentration) and reduced glutathione (GSH, $15.4 \mathrm{mg} / \mathrm{mL}, 50 \mathrm{mM}$ final concentration) in $0.1 \mathrm{M} \mathrm{pH} 7.2 \mathrm{ammonium}$ phosphate buffer $(3492 \mu \mathrm{L})$. The desulfurization was carried out at $25^{\circ} \mathrm{C}$ and monitored by MALDI-TOF mass spectrometry.

After $25 \mathrm{~h}$, the reaction product was purified by HPLC to yield $311 \mu \mathrm{g}(51 \%)$ of conjugate $8 \mathrm{a}$.

Semi-preparative HPLC conditions: XBridge BEH300 C18 ( $5 \mu \mathrm{m}, 300 \AA, 10 \times 250 \mathrm{~mm}$ ) column, eluent A water containing $0.1 \%$ of TFA, eluent $\mathrm{B} \mathrm{CH}_{3} \mathrm{CN} /$ water : $4 / 1$ by vol containing $0.1 \%$ of TFA, gradient: $0-10 \% \mathrm{~B}$ in 5 $\min , 10-100 \% \mathrm{~B}$ in $15 \mathrm{~min}$ flow rate $6 \mathrm{~mL} / \mathrm{min}$, UV detection at $215 \mathrm{~nm}, 50^{\circ} \mathrm{C}$.

SUM0-2 conjugate 8a: ADEKPK(ADEKPKEGVKTENNDHINLKVAGQDGSVVQFKIKRHTPLSKLMKAYCERQGLSMRQIRFRFDGQPINETDTPAQLEMEDEDTIDVFQQQTGGA)EGVKTENNDHINLK-NH ${ }_{2}$

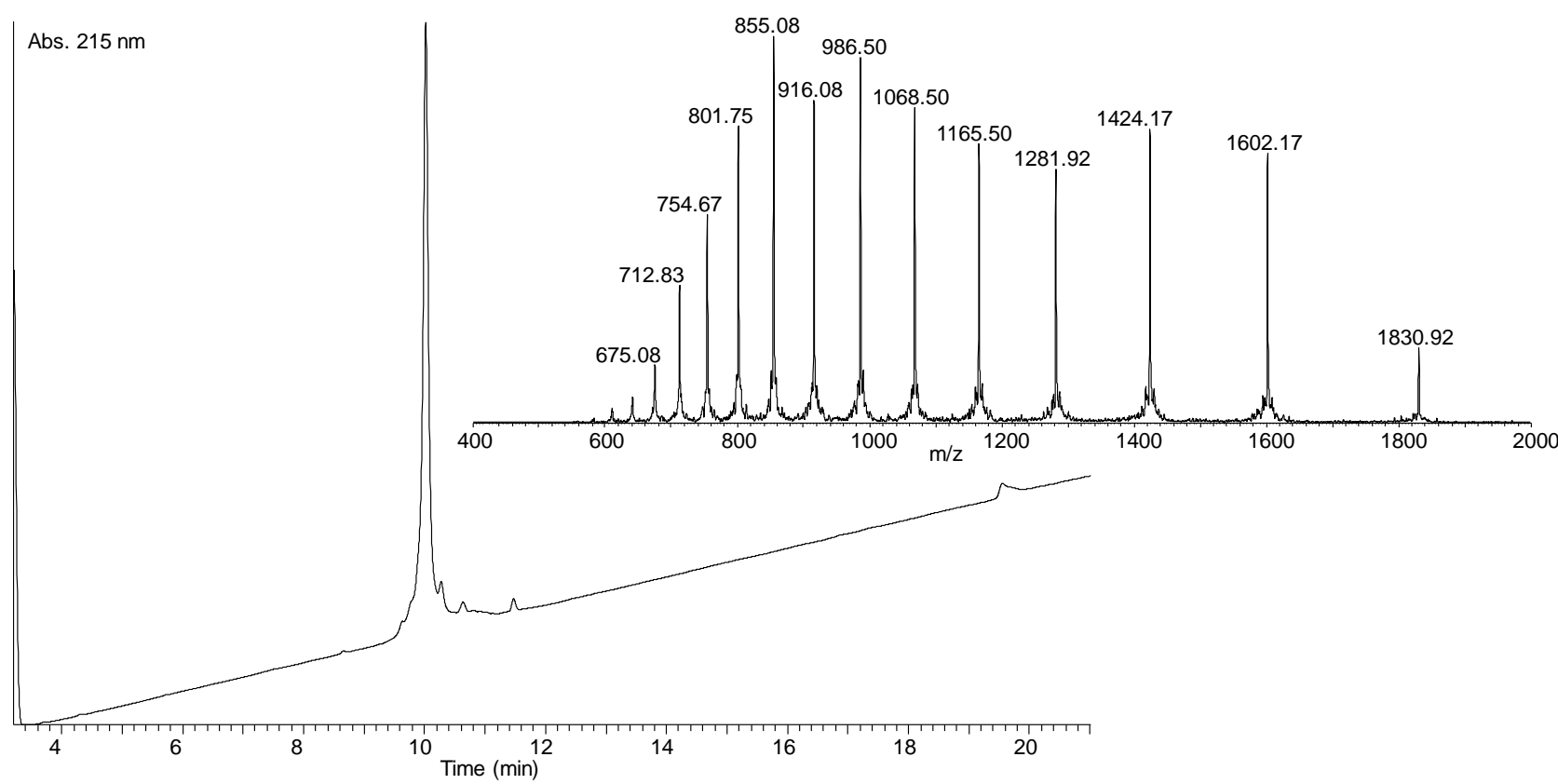

Figure S 17. Analysis of conjugate 8a. UPLC-MS analysis ACQUITY UPLC peptide BEH C18 $300 \AA 1.7 \mu \mathrm{m} 2.1$ $\mathrm{mm} \times 150 \mathrm{~mm}, 50^{\circ} \mathrm{C}$. Flow $0.400 \mathrm{~mL} / \mathrm{min}$, eluent $A 0.1 \%$ trifluoroacetic acid in water, eluent $B 0.1 \%$ trifluoroacetic acid in $100 \%$ acetonitrile. Gradient from $0 \%$ eluent B to $70 \%$ eluent B in 20 min. HPLC trace (UV detection) and MS trace. Calculated for M (average mass) 12809.32, observed 12809.75 after deconvolution. 


\section{2) Desulfurization of conjugate 7a in denaturing conditions}

Conjugate $7 \mathrm{a}(0.657 \mathrm{mg}, 0.510 \mu \mathrm{mol}, 0.100 \mathrm{mM}$ final concentration) was dissolved in a solution of TCEP ( 57.3 $\mathrm{mg} / \mathrm{mL}, 200 \mathrm{mM}$ final concentration), 2,2'-azobis[2-(2-imidazolin-2-yl)propane]dihydrochloride (VA-044, 6.5 $\mathrm{mg} / \mathrm{mL}, 20 \mathrm{mM}$ final concentration) and reduced glutathione (GSH, $15.4 \mathrm{mg} / \mathrm{mL}, 50 \mathrm{mM}$ final concentration) in $0.1 \mathrm{M} \mathrm{pH} 7.2$ ammonium phosphate buffer/6 M Gn. HCl $(3492 \mu \mathrm{L})$. The desulfurization was carried out at $25^{\circ} \mathrm{C}$ and monitored by MALDI-TOF mass spectrometry.

After $23 \mathrm{~h}$, the reaction product was purified by HPLC to yield $440 \mu \mathrm{g}(67 \%)$ of pure conjugate $9 \mathrm{a}$.

Semi-preparative HPLC conditions: XBridge BEH300 C18 (5 $\mu \mathrm{m}, 300 \AA, 10 \times 250 \mathrm{~mm})$ column, eluent A water containing $0.1 \%$ of TFA, eluent $\mathrm{B} \mathrm{CH} \mathrm{CH}_{3} \mathrm{CN} /$ water : $4 / 1$ by vol containing $0.1 \%$ of TFA, gradient: $0-10 \% \mathrm{~B}$ in 5 $\min , 10-100 \% \mathrm{~B}$ in $15 \mathrm{~min}$ flow rate $6 \mathrm{~mL} / \mathrm{min}$, UV detection at $215 \mathrm{~nm}, 50^{\circ} \mathrm{C}$.

SUMO-2 conjugate 9a: ADEKPK(ADEKPKEGVKTENNDHINLKVAGQDGSVVQFKIKRHTPLSKLMKAYAERQGLSMRQIRFRFDGQPINETDTPAQLEMEDEDTIDVFQQQTGGA)EGVKTENNDHINLK-NH ${ }_{2}$

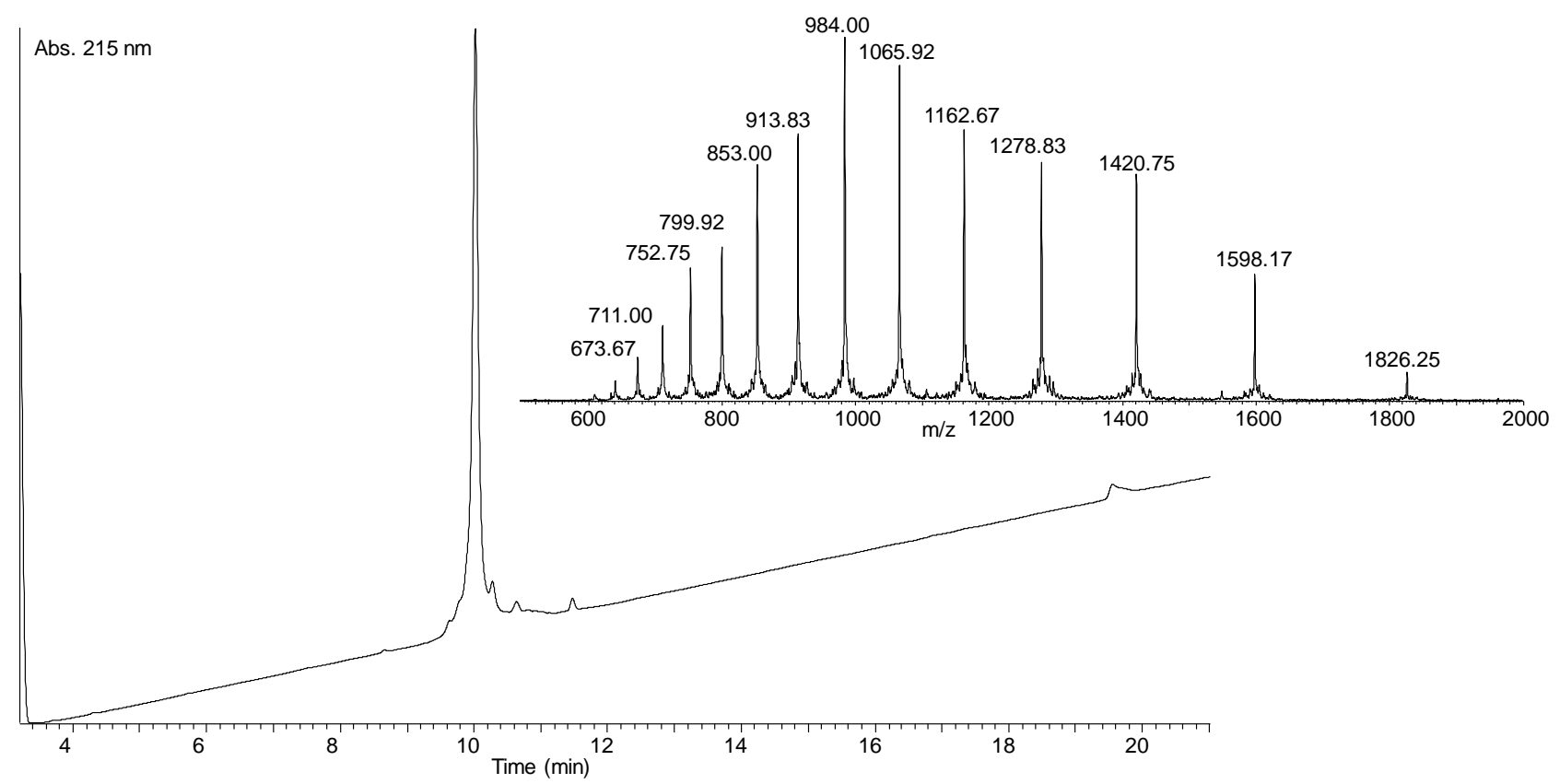

Figure S 18. Analysis of conjugate 9a. UPLC-MS analysis ACQUITY UPLC peptide BEH C18 $300 \AA 1.7 \mu \mathrm{m} 2.1$ $\mathrm{mm} \times 150 \mathrm{~mm}, 50^{\circ} \mathrm{C}$. Flow $0.400 \mathrm{~mL} / \mathrm{min}$, eluent $\mathrm{A} 0.1 \%$ trifluoroacetic acid in water, eluent $B 0.1 \%$ trifluoroacetic acid in $100 \%$ acetonitrile. Gradient from $0 \%$ eluent B to $70 \%$ eluent B in 20 min. HPLC trace (UV detection) and MS trace. Calculated for M (average mass) 12777.26, observed 12778.71 after deconvolution. 


\section{3) Desulfurization of conjugate $7 \mathrm{~b}$ in native conditions}

Conjugate $7 \mathrm{~b}(0.9 \mathrm{mg}, 0.7 \mu \mathrm{mol}, 0.1 \mathrm{mM}$ final concentration) was dissolved in a solution of TCEP $(57.4 \mathrm{mg} / \mathrm{mL}$, $200 \mathrm{mM}$ final concentration), 2,2'-azobis[2-(2-imidazolin-2-yl)propane]dihydrochloride (VA-044, $6.5 \mathrm{mg} / \mathrm{mL}$, $20 \mathrm{mM}$ final concentration) and reduced glutathione (GSH, $15.4 \mathrm{mg} / \mathrm{mL}, 50 \mathrm{mM}$ final concentration) in $0.1 \mathrm{M}$ pH 7.2 ammonium phosphate buffer $(935 \mu \mathrm{L})$. The desulfurization was carried out at $25^{\circ} \mathrm{C}$ and monitored by MALDI-TOF mass spectrometry.

After $25 \mathrm{~h}$, the reaction product was purified by HPLC to yield $371 \mu \mathrm{g}$ ( $37 \%$ ) of pure conjugate $8 \mathbf{b}$.

Semi-preparative HPLC conditions: XBridge BEH300 C18 (5 $\mu \mathrm{m}, 300 \AA, 10 \times 250 \mathrm{~mm})$ column, eluent A water containing $0.1 \%$ of TFA, eluent $\mathrm{B} \mathrm{CH}_{3} \mathrm{CN} /$ water : $4 / 1$ by vol containing $0.1 \%$ of TFA, gradient: $0-10 \% \mathrm{~B}$ in 5 $\min , 10-100 \% B$ in $15 \mathrm{~min}$ flow rate $6 \mathrm{~mL} / \mathrm{min}$, UV detection at $215 \mathrm{~nm}, 50^{\circ} \mathrm{C}$.

SUMO-3 conjugate 8b: ADEKPK(SEEKPKEGVKTENDHINLKVAGQDGSVVQFKIKRHTPLSKLMKAYCERQGLSMRQIRFRFDGQPINETDTPAQLEMEDEDTIDVFQQQTGGA)EGVKTENNDHINLK-NH ${ }_{2}$

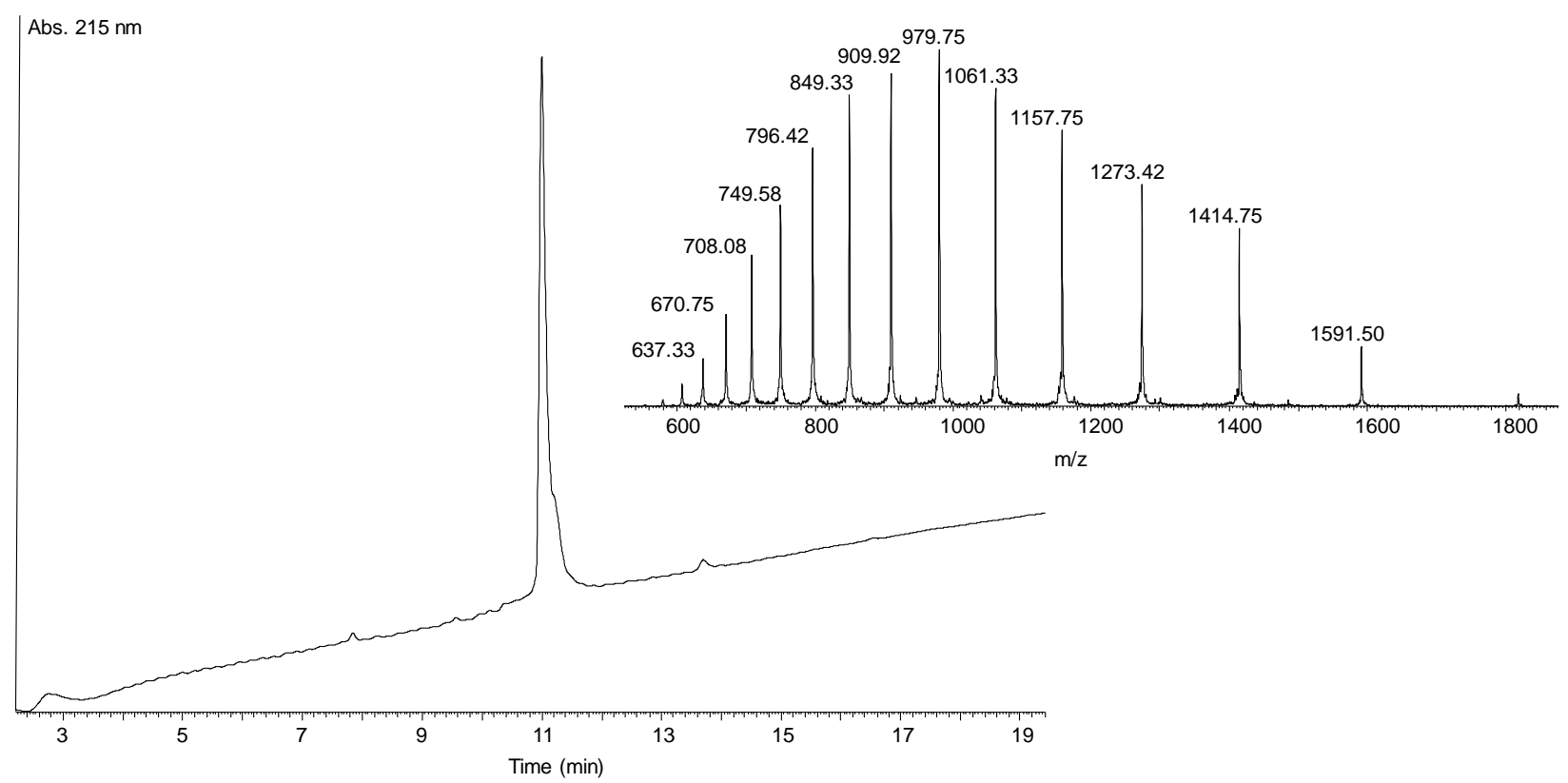

Figure S24. Analysis of conjugate 8b. UPLC-MS analysis ACQUITY UPLC peptide BEH C18 $300 \AA 1.7 \mu \mathrm{m} 2.1 \mathrm{~mm}$ $\times 150 \mathrm{~mm}, 50^{\circ} \mathrm{C}$. Flow $0.400 \mathrm{~mL} / \mathrm{min}$, eluent $A 0.1 \%$ trifluoroacetic acid in water, eluent $B 0.1 \%$ trifluoroacetic acid in $100 \%$ acetonitrile. Gradient from $0 \%$ eluent B to $70 \%$ eluent B in 20 min. HPLC trace (UV detection) and MS trace Calculated for M (average mass) 12725.18 , observed 12723.80 after deconvolution. 


\section{4) Desulfurization of conjugate $7 \mathrm{~b}$ in denaturing conditions}

Conjugate $\mathbf{7 b}(1.1 \mathrm{mg}, 0.86 \mu \mathrm{mol}, 0.10 \mathrm{mM}$ final concentration) was dissolved in a solution of TCEP (57.4 $\mathrm{mg} / \mathrm{mL}, 200 \mathrm{mM}$ final concentration), 2,2'-azobis[2-(2-imidazolin-2-yl)propane]dihydrochloride (VA-044, 6.5 $\mathrm{mg} / \mathrm{mL}, 20 \mathrm{mM}$ final concentration) and reduced glutathione ( $\mathrm{GSH}, 15.4 \mathrm{mg} / \mathrm{mL}, 50 \mathrm{mM}$ final concentration) in $0.1 \mathrm{M} \mathrm{pH} 7.2$ ammonium phosphate buffer $/ 6 \mathrm{M} \mathrm{Gn} \cdot \mathrm{HCl}(941 \mu \mathrm{L})$. The desulfurization was carried out at 25 ${ }^{\circ} \mathrm{C}$ and monitored by MALDI-TOF mass spectrometry.

After $23 \mathrm{~h}$, the reaction product was purified by HPLC to yield $371 \mu \mathrm{g}(37 \%)$ of pure conjugate $9 \mathrm{~b}$.

Semi-preparative HPLC conditions: XBridge BEH300 C18 (5 $\mu \mathrm{m}, 300 \AA, 10 \times 250 \mathrm{~mm})$ column, eluent A water containing $0.1 \%$ of TFA, eluent $\mathrm{B} \mathrm{CH} \mathrm{CH}_{3} \mathrm{CN} /$ water : $4 / 1$ by vol containing $0.1 \%$ of TFA, gradient: $0-10 \% \mathrm{~B}$ in 5 min, $10-100 \% B$ in $15 \mathrm{~min}$ flow rate $6 \mathrm{~mL} / \mathrm{min}$, UV detection at $215 \mathrm{~nm}, 50^{\circ} \mathrm{C}$.

SUMO-3 conjugate 9b: ADEKPK(SEEKPKEGVKTENDHINLKVAGQDGSVVQFKIKRHTPLSKLMKAYAERQGLSMRQIRFRFDGQPINETDTPAQLEMEDEDTIDVFQQQTGGA)EGVKTENNDHINLK-NH ${ }_{2}$

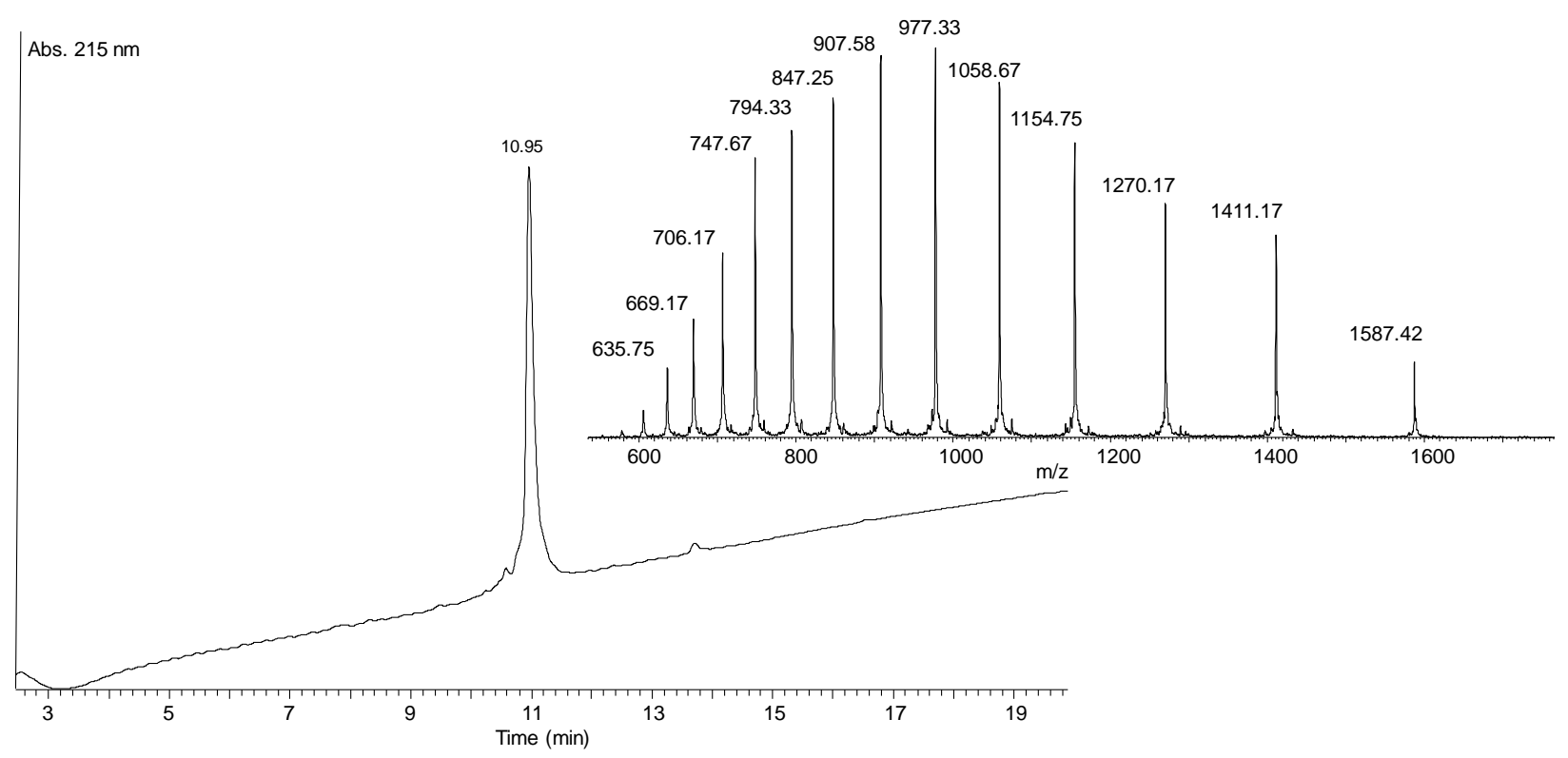

Figure S25. Analysis of conjugate 9b. UPLC-MS analysis ACQUITY UPLC peptide BEH C18 $300 \AA 1.7 \mu \mathrm{m} 2.1 \mathrm{~mm}$ $\times 150 \mathrm{~mm}, 50^{\circ} \mathrm{C}$. Flow $0.400 \mathrm{~mL} / \mathrm{min}$, eluent $A 0.1 \%$ trifluoroacetic acid in water, eluent $B 0.1 \%$ trifluoroacetic acid in $100 \%$ acetonitrile. Gradient from $0 \%$ eluent B to $70 \%$ eluent B in 20 min. HPLC trace (UV detection) and MS trace. Calculated for M (average mass) 12693.18, observed 12692.17 after deconvolution. 


\section{Proteomics analysis of recombinant SUMO-2 and 3 proteins and SUMO conjugates}

Proteins were dissolved in $25 \mathrm{mM}$ ammonium bicarbonate $\mathrm{pH} 7.8(1 \mathrm{mg} / \mathrm{mL})$. The protein solution $(5 \mu \mathrm{g}$ of protein) was mixed with DTT $(5 \mu \mathrm{g})$ and iodoacetamide $(50 \mu \mathrm{g})$. After $30 \mathrm{~min}$, trypsin solution in $25 \mathrm{mM}$ ammonium bicarbonate $(100 \mathrm{ng} / \mu \mathrm{L})$ was added on the above solution. The mixture was incubated at $37{ }^{\circ} \mathrm{C}$ overnight. The solution was directly spotted on a MALDI plate and mixed with $\alpha$-cyano-4-hydroxycinnamic acid or 2,5-dihydroxybenzoic acid before analysis.

1) Proteomic analysis of $r_{1}-S U M O-2 ~ \& 3$ Boston Biochem (ref. UL-752 \& UL-762) $r_{1}$-SUMO-2:

ADEKPKEGVKTENNDHINLKVAGQDGSVVQFKIKRHTPLSKLMAKYCERQGLSMRQIRFRFDGQPINETDTPAQLEMEDEDTIDVFQQQTGG

1165.17

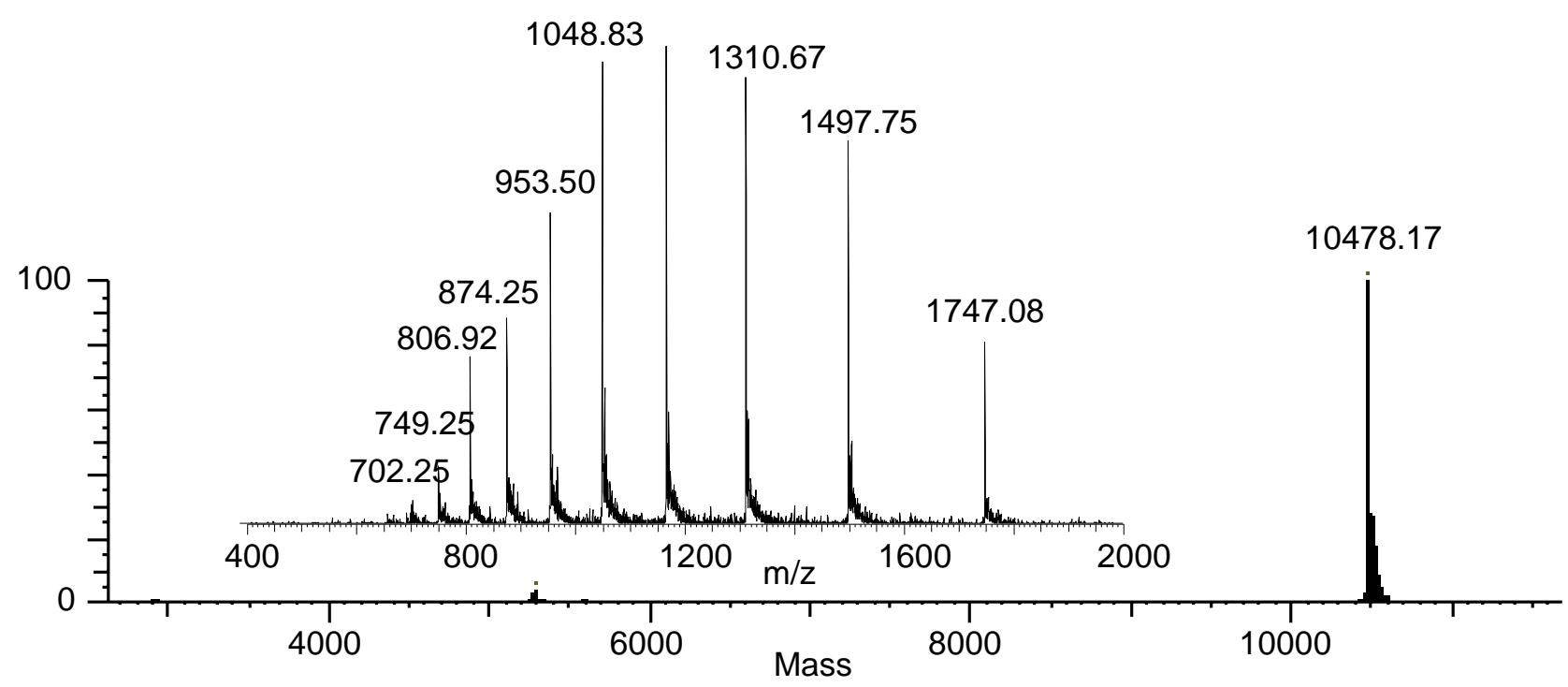

Figure $S$ 19. Analysis of $r_{1}$-SUMO-2 protein. UPLC-MS analysis ATLANTIS waters column T3 $3 \mu \mathrm{m} 2.1 \mathrm{~mm} \times 50$ $\mathrm{mm}, 50^{\circ} \mathrm{C}$. Flow $0.400 \mathrm{~mL} / \mathrm{min}$, eluent $A 0.1 \%$ trifluoroacetic acid in water, eluent $B 0.1 \%$ trifluoroacetic acid in $100 \%$ acetonitrile. Gradient from $0 \%$ eluent B to $70 \%$ eluent B in 4 min. MS trace. Calculated for M (average mass) 10477.19 observed 10478.17 after deconvolution. 

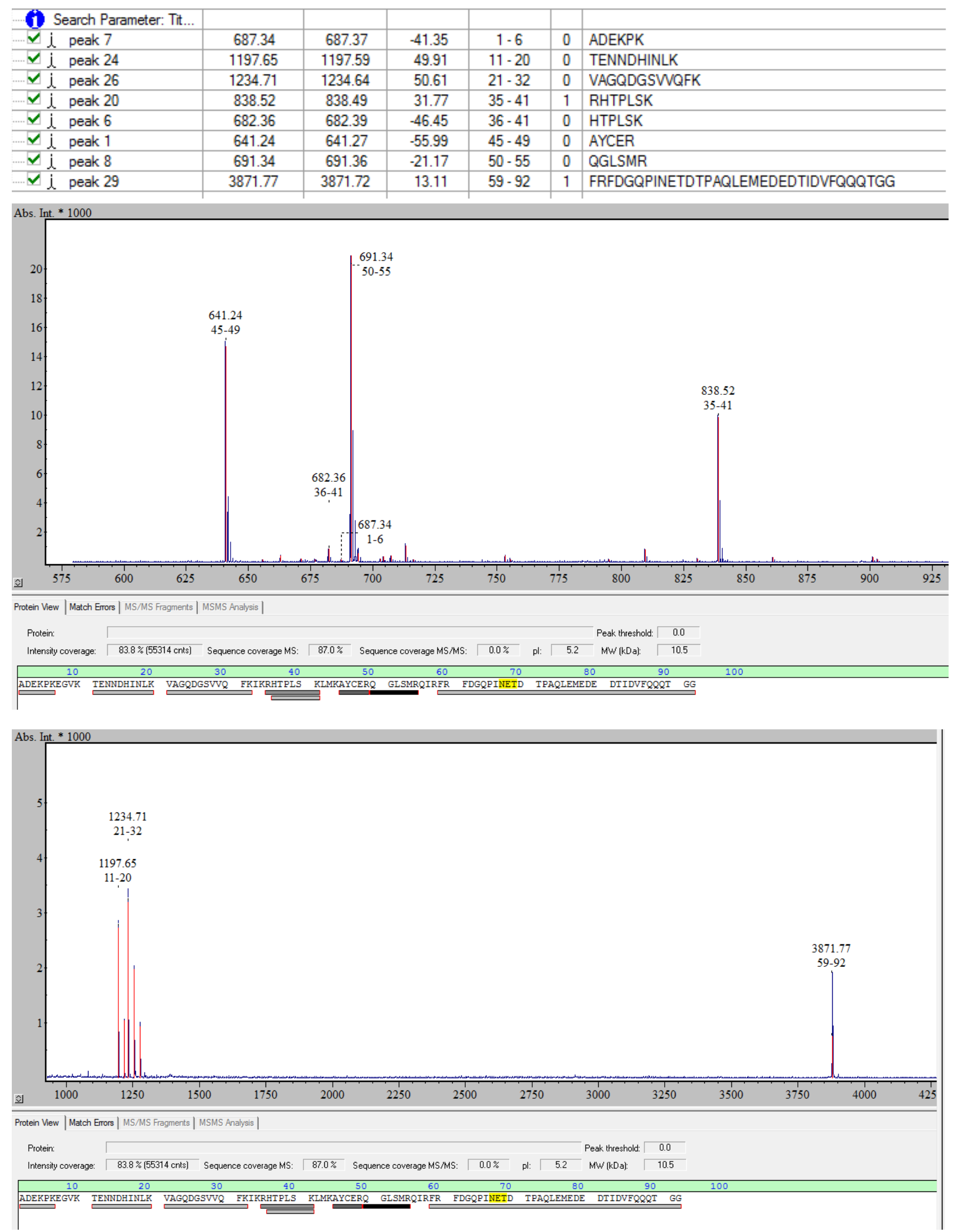

Figure S 20. MALDI-TOF spectra of the fragments generated after reduction, alkylation and trypsin cleavage of $r_{1}$-SUMO-2 (ref. UL-752). 


\section{CERQGLSMRQIRFRFDGQPINETDTPAQLEMEDEDTIDVFQQQTGG}

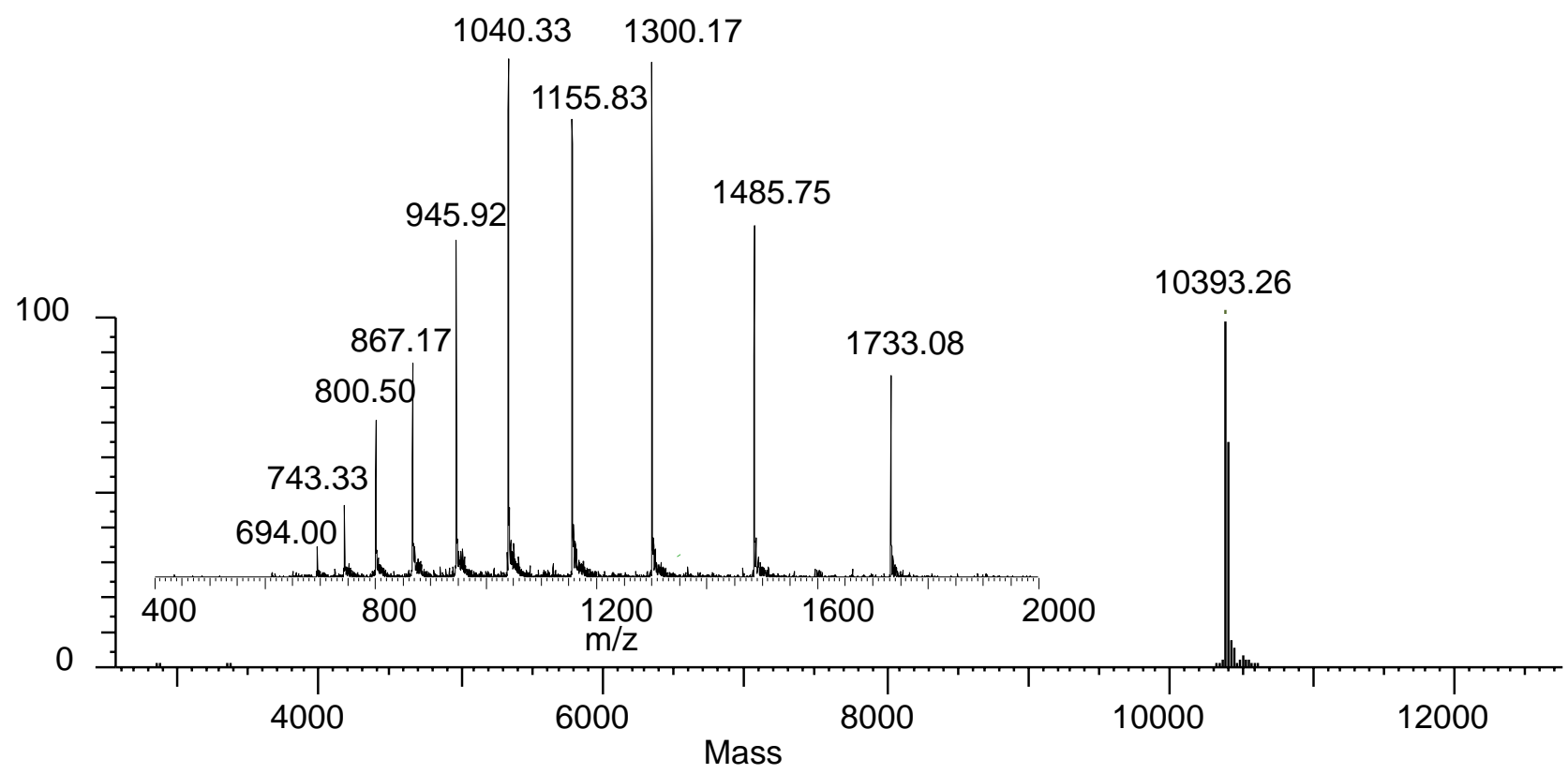

Figure S 21. Analysis of $r_{1}$-SUMO-3 protein. UPLC-MS analysis ATLANTIS waters column T3 $3 \mu \mathrm{m} 2.1 \mathrm{~mm} \times 50$ $\mathrm{mm}, 50^{\circ} \mathrm{C}$. Flow $0.400 \mathrm{~mL} / \mathrm{min}$, eluent $\mathrm{A} 0.1 \%$ trifluoroacetic acid in water, eluent $B 0.1 \%$ trifluoroacetic acid in $100 \%$ acetonitrile. Gradient from $0 \%$ eluent B to $70 \%$ eluent B in 4 min. MS trace. Calculated for M (average mass) 10393.66, observed 10393.26 after deconvolution.

\begin{tabular}{|c|c|c|c|c|c|c|}
\hline \\
\hline \multicolumn{7}{|c|}{$\begin{array}{l}\text { Illt Digest Results } \\
1 \text { Search Parameter: Tit... }\end{array}$} \\
\hline \multicolumn{7}{|c|}{$\checkmark \mathrm{i}$ peak 11} \\
\hline \multicolumn{7}{|l|}{$\checkmark \hat{\mathrm{l}}$ peak 12} \\
\hline \multicolumn{7}{|l|}{$\checkmark$ l peak 10} \\
\hline \multicolumn{7}{|l|}{$\checkmark \mathrm{i}$ peak 1} \\
\hline \multirow{2}{*}{\multicolumn{7}{|c|}{$\begin{array}{l}\text { QGLSMR } \\
\text { FRFDGQPINETDTPAQLEMEDEDTIDVFQQQTGG }\end{array}$}} \\
\hline & 3871.85 & 3871.72 & 32.49 & $58-91$ & 1 & FRFDGQPINETDTPAQLEMEDEDTIDVFQQQTGG \\
\hline
\end{tabular}



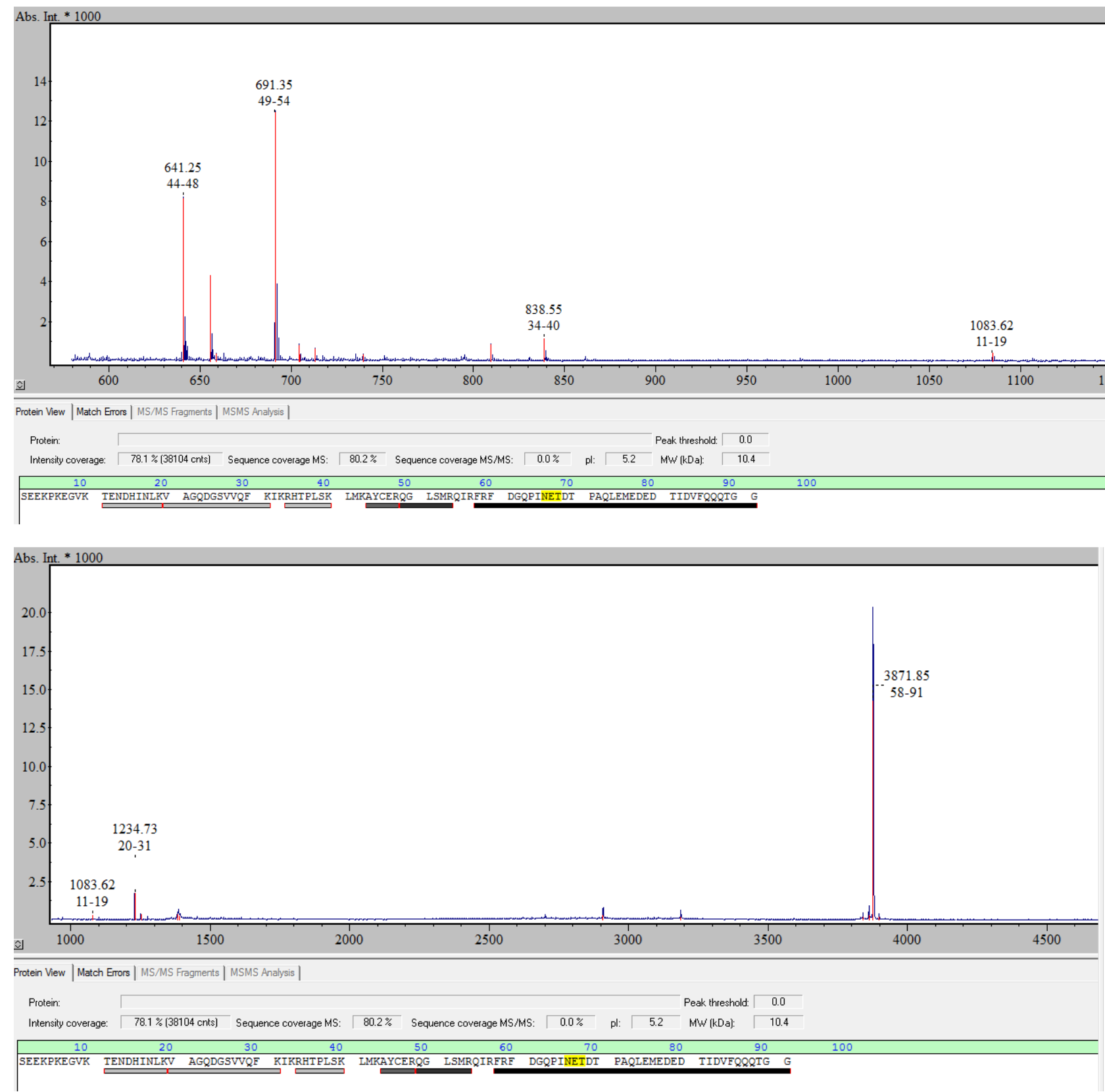

Figure S 22. MALDI-TOF spectra of the fragments generated after reduction, alkylation and trypsin cleavage of $r_{1}$-SUMO-3 (ref. UL-762). 


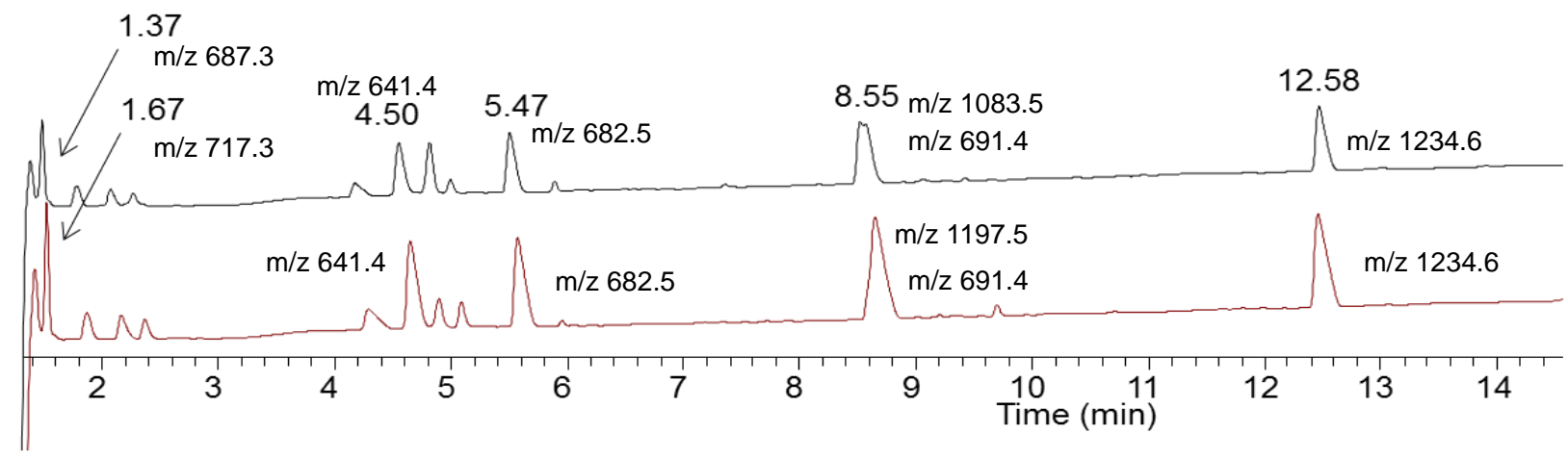

Figure S 23. Analysis of trypsin digests. UPLC-MS analysis ACQUITY UPLC peptide BEH C18 $300 \AA 1.7 \mu \mathrm{m} 4.6$ $\mathrm{mm} \times 150 \mathrm{~mm}, 50^{\circ} \mathrm{C}$. Flow $0.400 \mathrm{~mL} / \mathrm{min}$, eluent $A 0.1 \%$ trifluoroacetic acid in water, eluent $B 0.1 \%$ trifluoroacetic acid in $100 \%$ acetonitrile. Gradient from $0 \%$ eluent B to $70 \%$ eluent B in 20 min. HPLC trace (light scattering detection) and MS data, $\mathrm{r}_{1}-\mathrm{SUMO}-2$ in red, $\mathrm{r}_{1}$-SUMO-3 in black.

2) Proteomic analysis of SUMO-2 conjugates 7-9a

\begin{tabular}{|c|c|c|c|c|c|c|c|c|c|c|c|}
\hline \multicolumn{2}{|c|}{$5622.54 \mathrm{Da}$} & Mo. & \multirow[b]{2}{*}{-} & \multirow[b]{2}{*}{ Left: } & \multirow{2}{*}{\begin{tabular}{|c|} 
I \\
Hydrogen \\
\end{tabular}} & \multirow[t]{2}{*}{ 䉓 } & \multicolumn{2}{|c|}{2 Amino Acids } & \multirow{2}{*}{\begin{tabular}{|l|l|}
$5 \quad \square$ \\
Free Acid
\end{tabular}} & \multirow{2}{*}{\multicolumn{2}{|c|}{ interchain links: $\sqsubset$}} \\
\hline Cys: & Carbami & idomethyl [C] & & & & & -1 & Right: & & & \\
\hline \multicolumn{12}{|c|}{ New interchain set0 } \\
\hline FRFDG & $\begin{array}{r}10 \\
\text { QPINE }\end{array}$ & $\begin{array}{lr}20 \\
\text { TDTPA }\end{array}$ & DED & T I & $\begin{array}{rr}30 & \\
\text { UFQQ QTGGG }\end{array}$ & & & & & & \\
\hline EGUKT & $\begin{array}{r}10 \\
\text { ENIDH } \\
\end{array}$ & INLK & & & & & & & & & \\
\hline
\end{tabular}

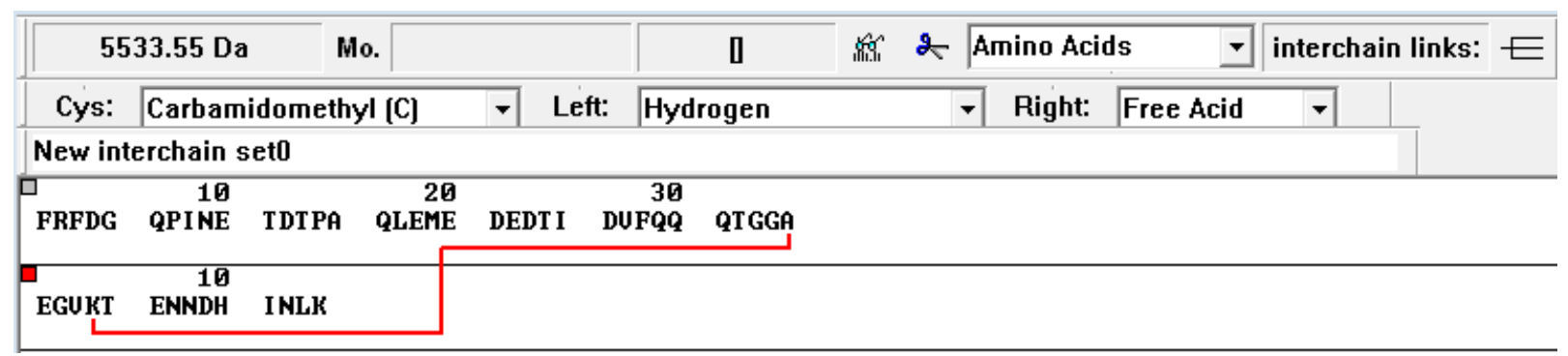

$\mathrm{m} / \mathrm{z}$ 2720.47, GSVVQFKIKRHTPLSKLMKAYC*E $\quad\left({ }^{*}\right.$ Carbamidomethyl(C)) $\mathrm{m} / \mathrm{z}$ 2631.48, GSVVQFKIKRHTPLSKLMKAYAE 


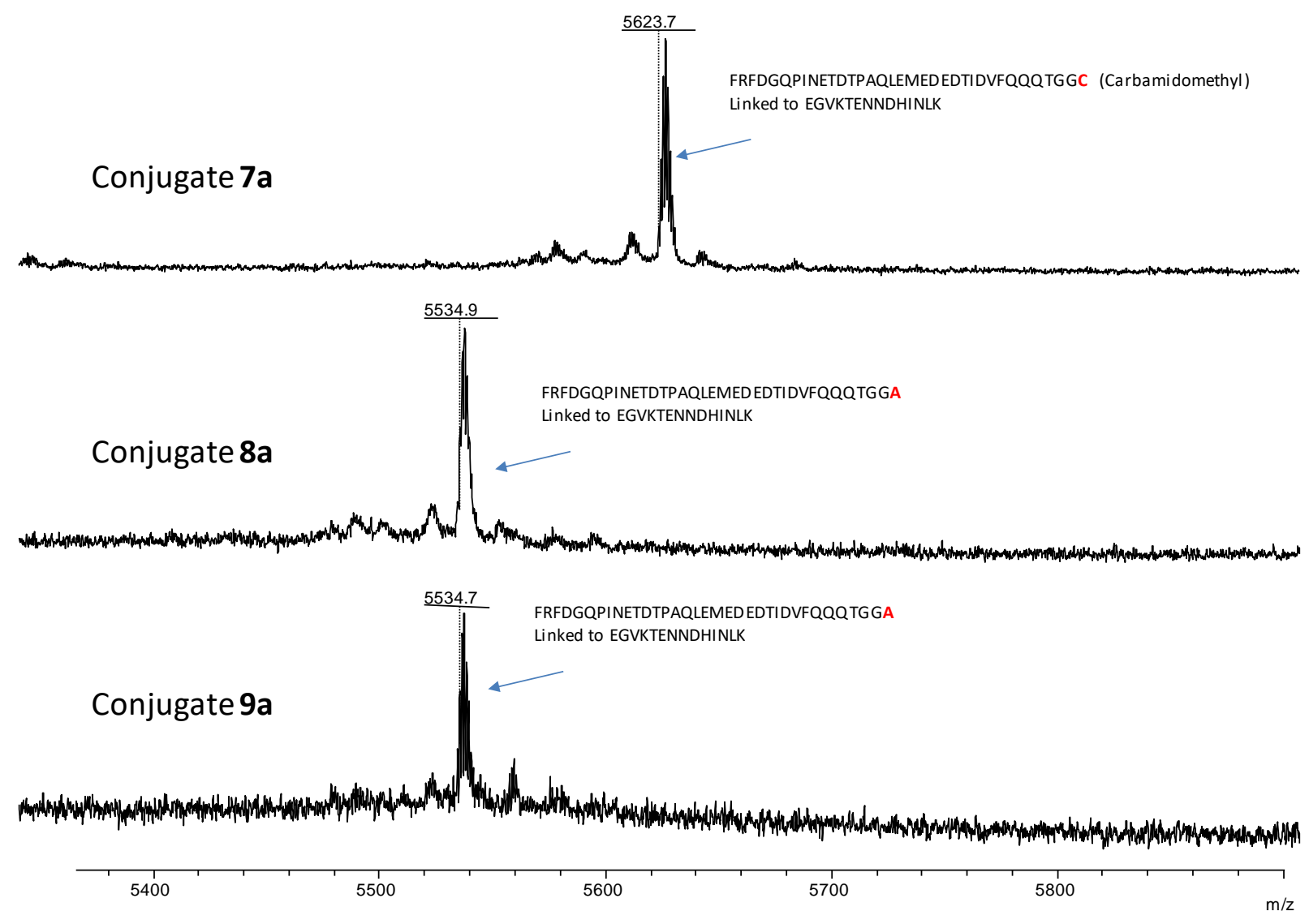

Figure S 24. MALDI-TOF spectra of the fragments generated after reduction, alkylation and trypsin cleavage of SUMO-2 conjugates 7-9a. 


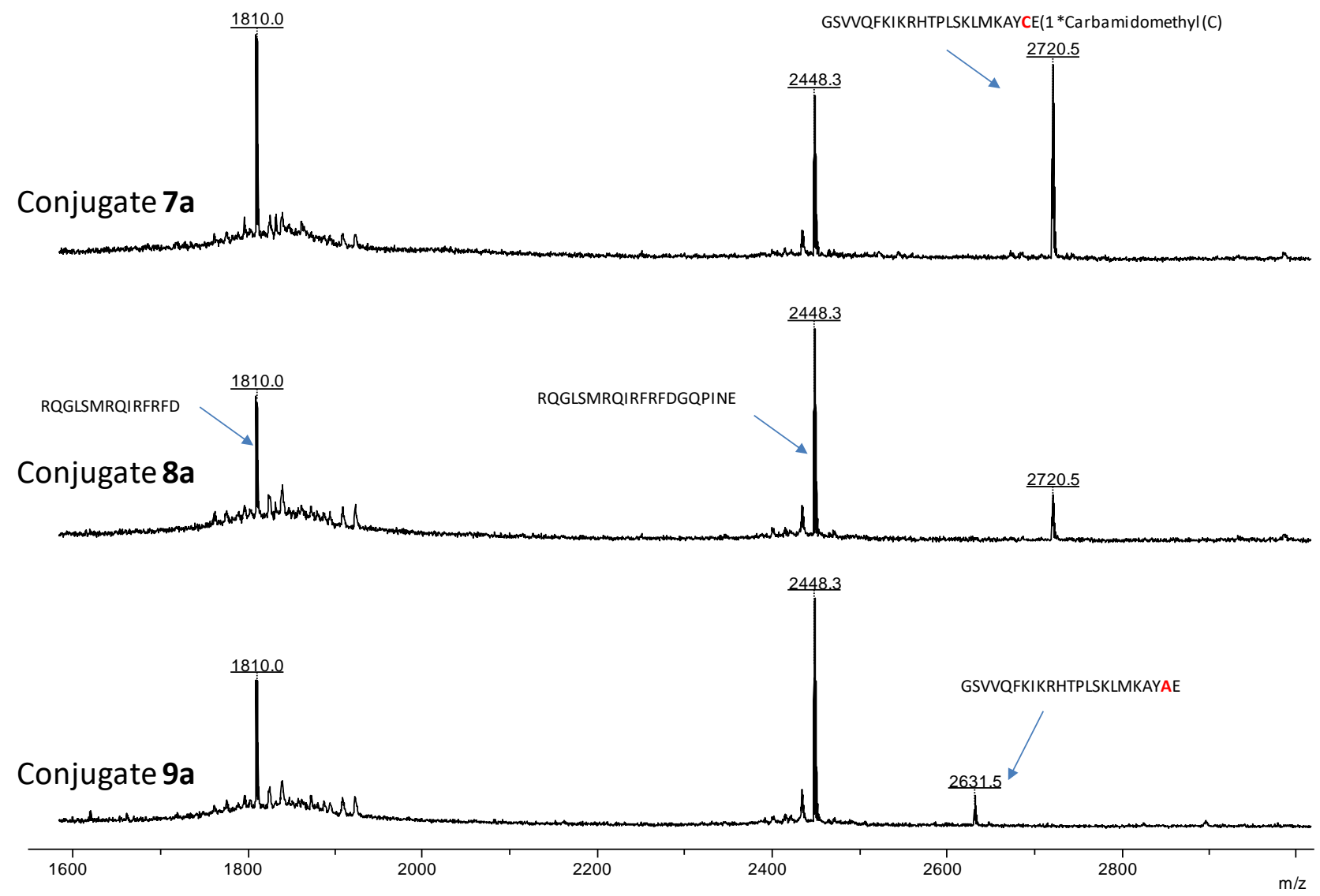

Figure S 25. MALDI-TOF spectra of the fragments generated after reduction, alkylation and Endo GluC cleavage of SUMO-2 conjugates 7-9a.

\section{3) Proteomic analysis of SUMO-3 conjugates 7-9b}

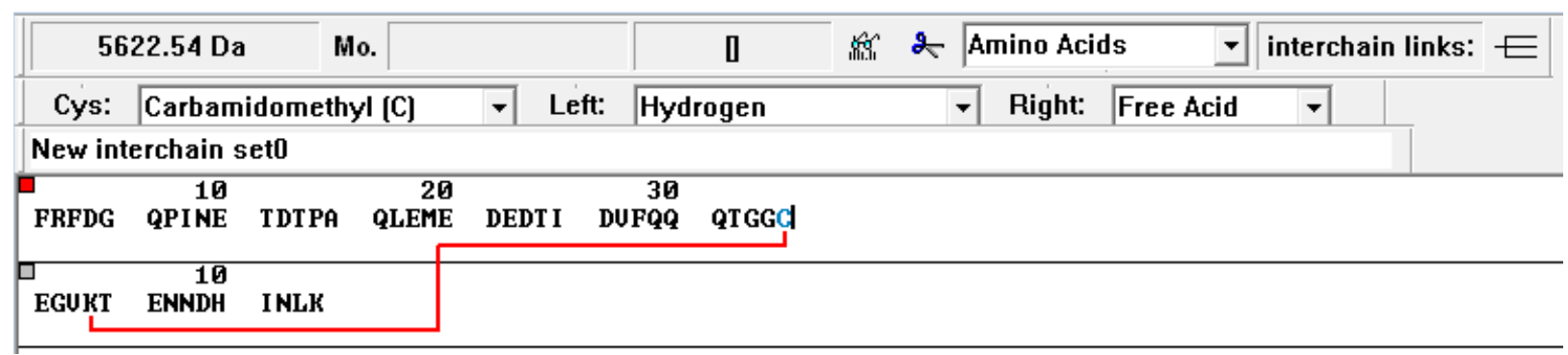

\begin{tabular}{|c|c|c|c|c|c|c|c|c|c|c|c|c|}
\hline \multicolumn{2}{|c|}{$5533.55 \mathrm{Da}$} & Mo. & \multirow[b]{2}{*}{$\nabla$} & \multirow[b]{2}{*}{ Left: } & \multicolumn{2}{|r|}{ ] } & \multirow[t]{2}{*}{ 舟霜 } & \multirow[t]{2}{*}{2} & Amino Acid & $\nabla$ & \multicolumn{2}{|c|}{ interchain links: $\sqsubset$} \\
\hline Cys: & Carbami & idomethyl [C] & & & Hyc & rogen & & & Right: & Free Acid & $\nabla$ & \\
\hline \multicolumn{13}{|c|}{ New interchain set0 } \\
\hline FRFDG & $\begin{array}{r}10 \\
\text { QPINE }\end{array}$ & $\begin{array}{lr} & 20 \\
\text { TDTPA } & \text { QLEME }\end{array}$ & DE] & & $\begin{array}{r}30 \\
\text { DUFQQ }\end{array}$ & QTGGA & & & & & & \\
\hline EGUKT & $\begin{array}{r}10 \\
\text { ENNDH }\end{array}$ & INLK & & & & & & & & & & \\
\hline
\end{tabular}

$\mathrm{m} / \mathrm{z}$ 2720.47, GSVVQFKIKRHTPLSKLMKAYC*E $\quad\left({ }^{*}\right.$ Carbamidomethyl(C)) $\mathrm{m} / \mathrm{z}$ 2631.48, GSVVQFKIKRHTPLSKLMKAYAE 


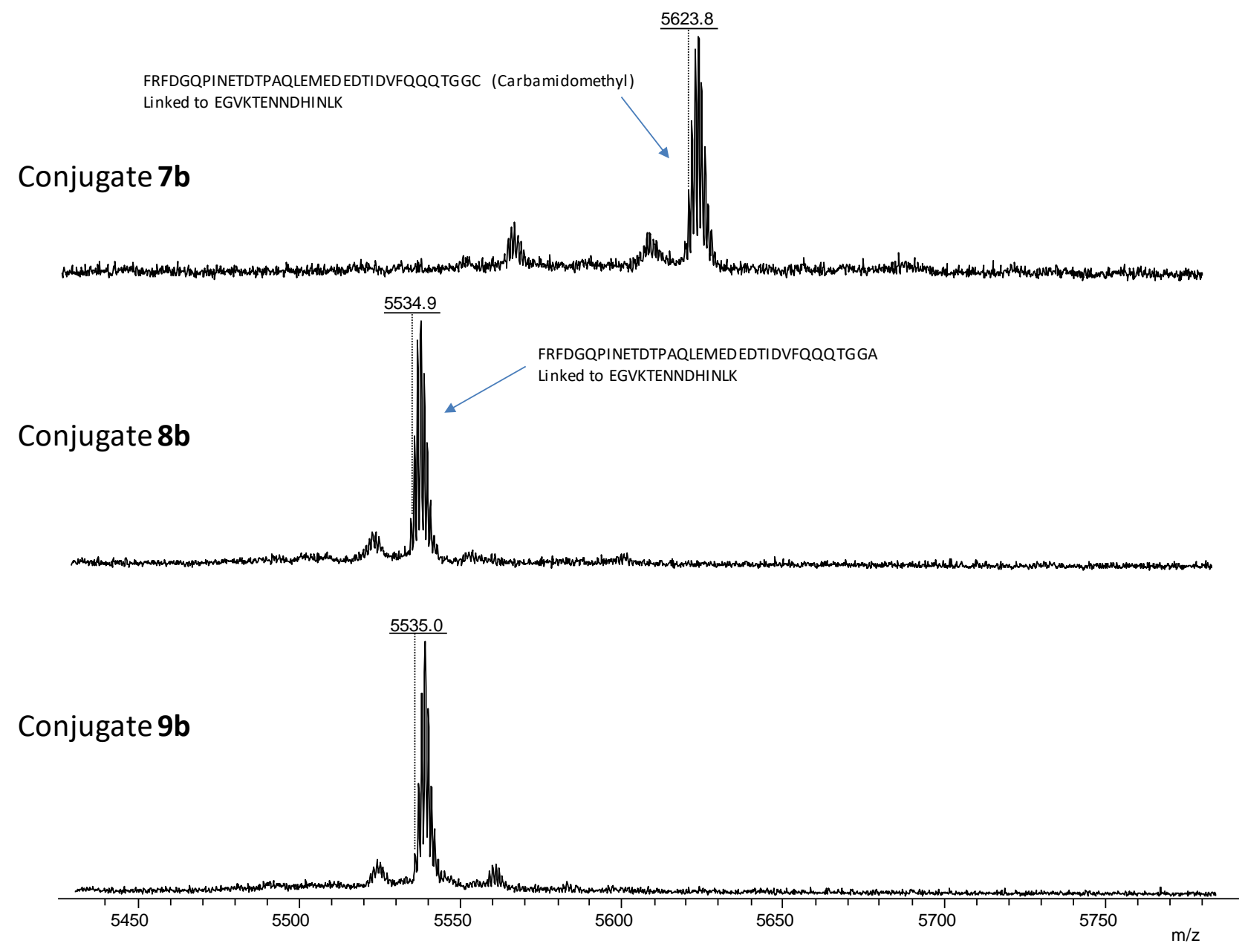

Figure S 26. MALDI-TOF spectra of the fragments generated after reduction, alkylation and trypsin cleavage of SUMO-3 conjugates 7-9b. 


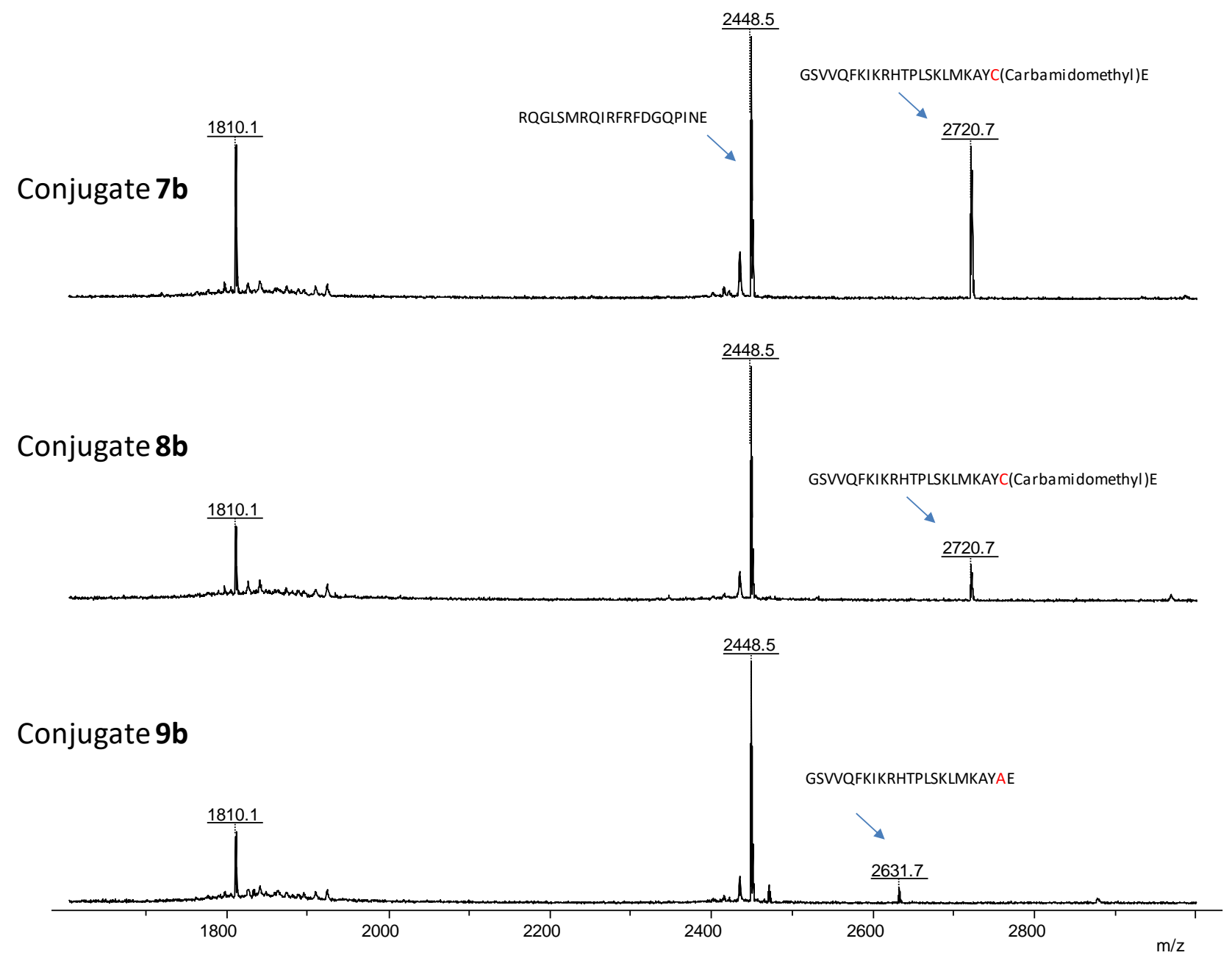

Figure S 27. MALDI-TOF spectra of the fragments generated after reduction, alkylation and Endo GluC cleavage of SUMO-3 conjugates 7-9b. 


\section{Biophysical and biochemical characterizations}

\section{A. Circular dichroism analysis}

The concentration of different SUMO proteins solubilized in $10 \mathrm{mM}$ sodium phosphate buffer was determined with Nanodrop. The stock solutions of SUMO proteins were diluted with sodium phosphate buffer (10 $\mathrm{mM}, \mathrm{pH}$ 7.2) to a final concentration of $12-40 \mu \mathrm{M}$ for analysis. The circular dichroism spectra were recorded on a CD6 spectropolarimeter (Jobin-Yvon).

CD spectra were measured at $25^{\circ} \mathrm{C}$ over the range $190-260 \mathrm{~nm}$ using $0.1 \mathrm{~cm}$ path-length cell and averaging 40 scans. A $2 \mathrm{~nm}$ bandwidth, $1 \mathrm{~nm}$ data pitch were used for spectral acquisition.

The $\alpha$-helical content of the proteins was estimated using the empirical equation of Green- field \& Fasman (Greenfield, N.; Fasman, G. D. Biochemistry 1969, 8, 4108.).

A)

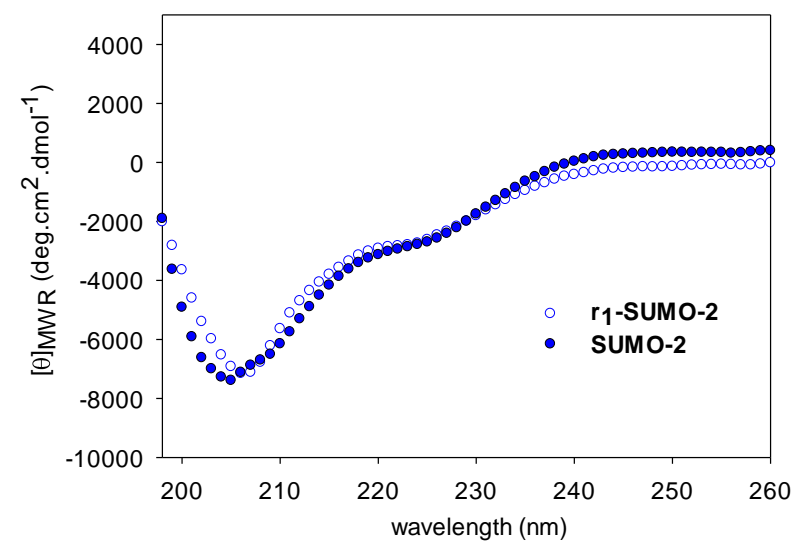

B)

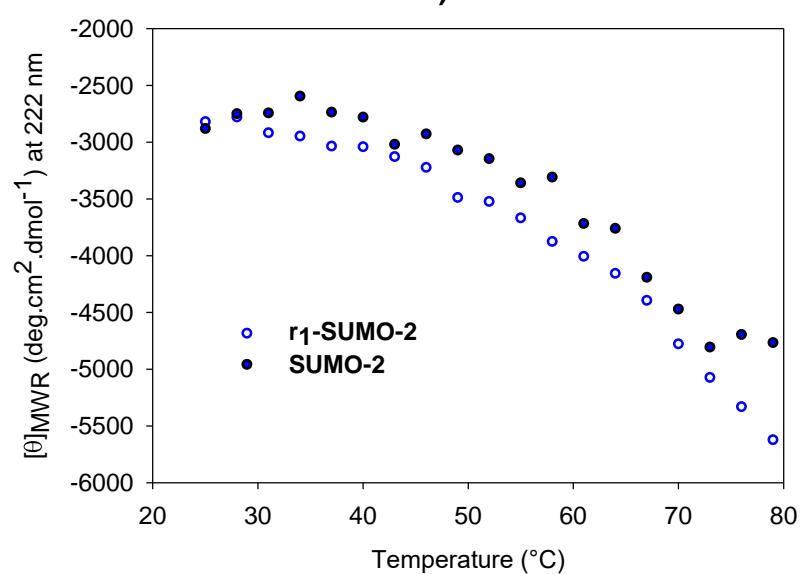

Figure $S$ 28. CD analysis of synthetic SUMO-2 and recombinant SUMO-2 protein ( $\left.\mathrm{r}_{1}-\mathrm{SUMO}-2\right)$. (10 mM phosphate buffer $\mathrm{pH} 7.2$ ). A) $\mathrm{CD}$ analysis at $25^{\circ} \mathrm{C}$. B) Thermal denaturation. The samples were carefully degassed during 30 min with argon and immediately transferred under argon into the CD cuvette.

A)

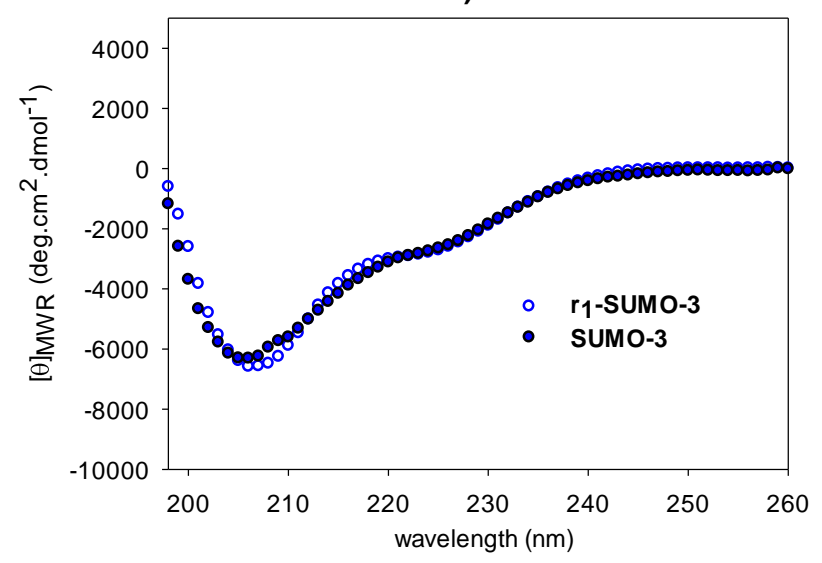

B)

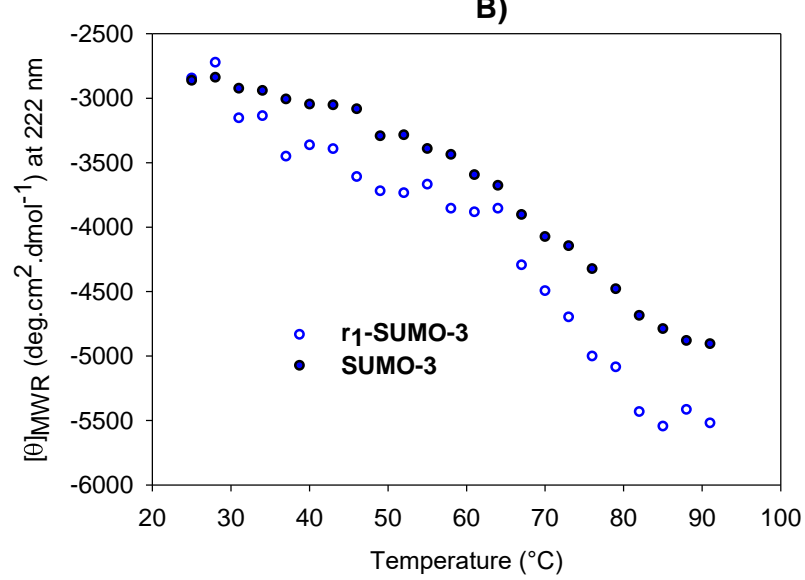

Figure $S$ 29. CD analysis of synthetic SUMO-3 and recombinant SUMO-3 protein ( $\left.r_{1}-S U M O-3\right)$. (10 mM phosphate buffer $\mathrm{pH} 7.2$ ). A) $\mathrm{CD}$ analysis at $25^{\circ} \mathrm{C}$. B) Thermal denaturation. The samples were carefully degassed during 30 min with argon and immediately transferred under argon into the CD cuvette. 
Table S 1. Table of 20 different pdb entries describing the structure of SUMO-2 or 3 proteins with determination of $\% \alpha$ helix.

\begin{tabular}{|c|c|c|c|c|c|}
\hline Pdb name & SUMO & Sequence & Modifications & Technique & $\% \alpha$ helix \\
\hline $2 \mathrm{RPQ}$ & SUMO-2/3 & $15-93$ & & NMR & $12 \%$ \\
\hline 2D07 & SUMO-2/3 & $15-89$ & & X-Ray & $16 \%$ \\
\hline $2 \mathrm{MP2}$ & SUMO-3 & $12-92$ & & NMR & $15 \%$ \\
\hline $2 \mathrm{~N} 1 \mathrm{~W}$ & pro-SUMO-2 & $1-93$ & & NMR & $10 \%$ \\
\hline $5 \mathrm{GHB}$ & SUMO-2 & $1-93$ & Lys 42 acetylated & NMR & $14 \%$ \\
\hline $5 \mathrm{GHC}$ & SUMO-2 & $1-93$ & Lys33 acetylated & NMR & $14 \%$ \\
\hline 2101 & SUMO-2/3 & $15-88$ & & X-Ray & $14 \%$ \\
\hline 2103 & SUMO-2/3 & $20-93$ & & X-Ray & $14 \%$ \\
\hline $2 I Y D$ & SUMO-2/3 & $14-92$ & & X-Ray & $14 \%$ \\
\hline $2 \mathrm{CKH}$ & SUMO-2/3 & $14-92$ & & X-Ray & $16 \%$ \\
\hline $1 \mathrm{WZO}$ & SUMO-2 & $8-100$ & & NMR & $11 \%$ \\
\hline $1 \mathrm{WM} 2$ & SUMO-2 & $12-89$ & & X-Ray & $17 \%$ \\
\hline 1WM3 & SUMO-2/3 & $17-88$ & & X-Ray & $15 \%$ \\
\hline $2 \mathrm{~N} 9 \mathrm{E}$ & SUMO-2 & $1-95$ & & NMR & $15 \%$ \\
\hline 2AWT & SUMO-2 & $12-89$ & & X-Ray & $11 \%$ \\
\hline $3 Z O 5$ & SUMO-2/3 & $16-95$ & & X-Ray & $16 \%$ \\
\hline $4 \mathrm{BKG}$ & SUMO-2 & $17-89$ & & X-Ray & $8 \%$ \\
\hline $2 \mathrm{MP} 2$ & SUMO-3 & $1-90$ & & NMR & $15 \%$ \\
\hline 2100 & SUMO-2/3 & $16-89$ & & X-Ray & $10 \%$ \\
\hline $5 \mathrm{D} 2 \mathrm{M}$ & SUMO-2/3 & $18-93$ & & X-Ray & $13 \%$ \\
\hline & & & & average $\% \alpha$ helix & $14 \%$ \\
\hline
\end{tabular}

\section{B. In vitro SUMOylation assay}

We performed a classical SUMO biochemical conjugation assay to see if the modification influences the enzyme-catalyzed formation of the isopeptidic bond using RanGAP as the target protein (Figure S 30A). We used for this purpose reagents from a commercially available conjugation kit (BML-UW8955-0001 from Enzo Life Sciences) and the procedure recommended by the manufacturer. The different SUMO analogues (i.e. the recombinant proteins from the kit $\mathrm{r}_{2}$-SUMO-2/3, synthetic wild-type SUMO-2 and 3 and synthetic desulfurized SUMO-2(3) C48A (C47A) were efficiently transferred with no apparent difference in the amount of RanGAP-SUMO conjugate formed whether SUMO-2 or 3 were desulfurized or not. Unexpectedly, isolated desulfurized proteins SUMO-2 C48A and SUMO-3 C47A were poorly recognized by the polyclonal anti-SUMO-2/3 antibody provided with the kit (Figure S $30 \mathrm{~A}$ ), while the corresponding RanGAP conjugates displayed a strong band in the same analysis. This observation was confirmed by Western blot analysis of the different SUMO analogues using the anti-SUMO-2/3 antibody from the kit (Figure $S \mathbf{3 0 B}$ ). The control for the loading is shown in Figure $\mathbf{S} \mathbf{3 0} \mathrm{C}$ using Coomassie staining. 


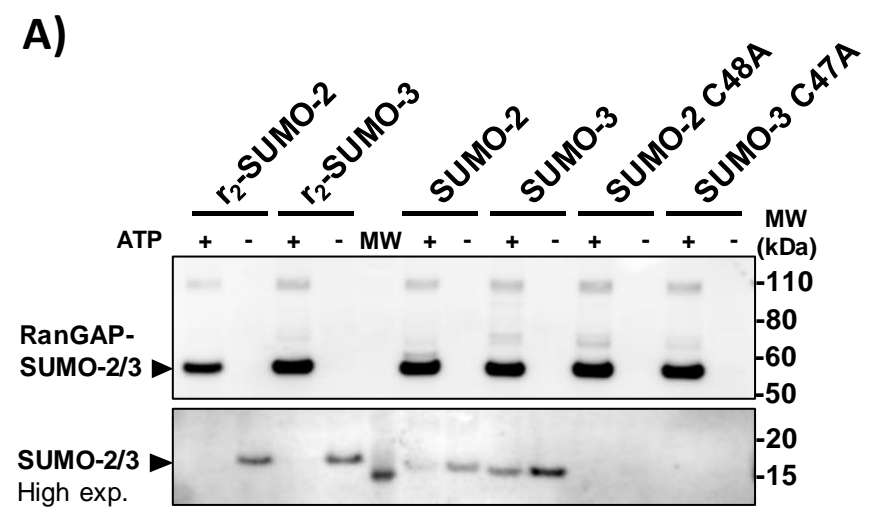

B)

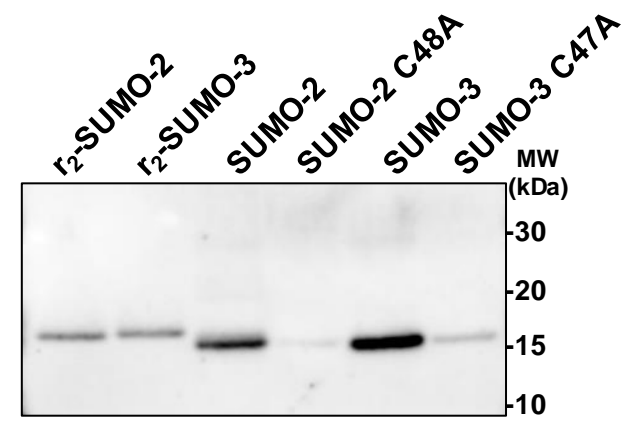

c)

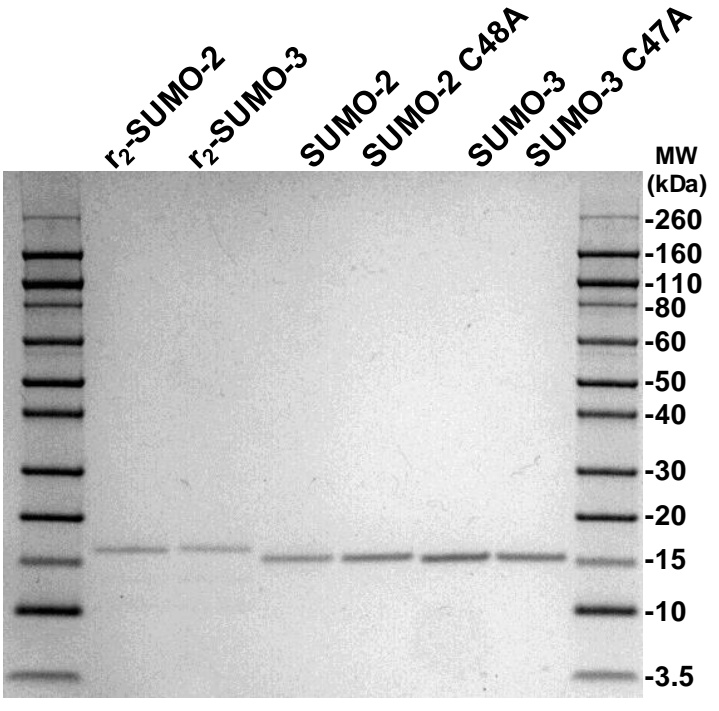

Figure S 30. A) Enzymatic conjugation assay using RanGAP protein as target protein. The assay was performed according to the manufacturer protocol using $100 \mathrm{ng}$ of the different SUMO proteins, including the recombinant His-tagged SUMO-2 and 3 proteins from the kit (noted $r_{2}$-SUMO-2 and $r_{2}$-SUMO-3). The presence of SUMO proteins was assayed by Western-blot using commercial anti-SUMO-2/3 antibody. B) Western-blot analysis of $\mathrm{r}_{2}$-SUMO-2 and $\mathrm{r}_{2}$-SUMO-3, synthetic wild-type SUMO-2 and 3 and synthetic desulfurized SUMO2 (3) C48A(C47A) (100 ng of each protein) using anti-SUMO-2/3 antibody. C) Coomassie staining of the different proteins $(1 \mu \mathrm{g}$ each). 


\section{Fluorescence Resonance Energy Transfert (FRET) analysis}

SUMOylation of CFP-RanGAPtail with YFP-SUMO-3 in presence of unlabeled SUMO-3 was carried out using a FRET-based high-thoughput assay as described previously. ${ }^{3,4}$ Briefly, 15 nM E1, 20 nM E2, 300 nM YFP-SUMO3, 300 nM CFP-RanGAPtail as YFP-SUMO-3 substrate in presence of unlabeled SUMO-3 WT or C47A (from 75 $\mathrm{nM}$ to $600 \mathrm{nM}$ ) were incubated together at $37^{\circ} \mathrm{C}$ or $42^{\circ} \mathrm{C}$ for 10 minutes in SAB+ buffer (110 mM KOAc, 20 mM HEPES [pH 7.3], $2 \mathrm{mM} \mathrm{Mg[OAc]} 2,1 \mathrm{mM}$ EGTA, supplemented with $1 \mu \mathrm{g} / \mathrm{mL}$ of each leupeptin, pepstatin and aprotinin, $1 \mathrm{mM}$ DTT, $0.05 \%$ Tween $\AA 20$ and $0.2 \mathrm{mg} / \mathrm{ml}$ ovalbumin). In vitro SUMOylation reaction was started upon addition of $1 \mathrm{mM}$ ATP. The SUMOylation of CFP-RanGAPtail by YFP-SUMO-3 was monitored using a microtiter plate reader (TECAN infinite M1000): upon excitation at $430 \mathrm{nM}$, the ratio between the emission at $527 \mathrm{nM}$ and at $485 \mathrm{nM}$ was determined every $20 \mathrm{sec}$.

1. Recombinant wild-type and desulfurized SUMO-3
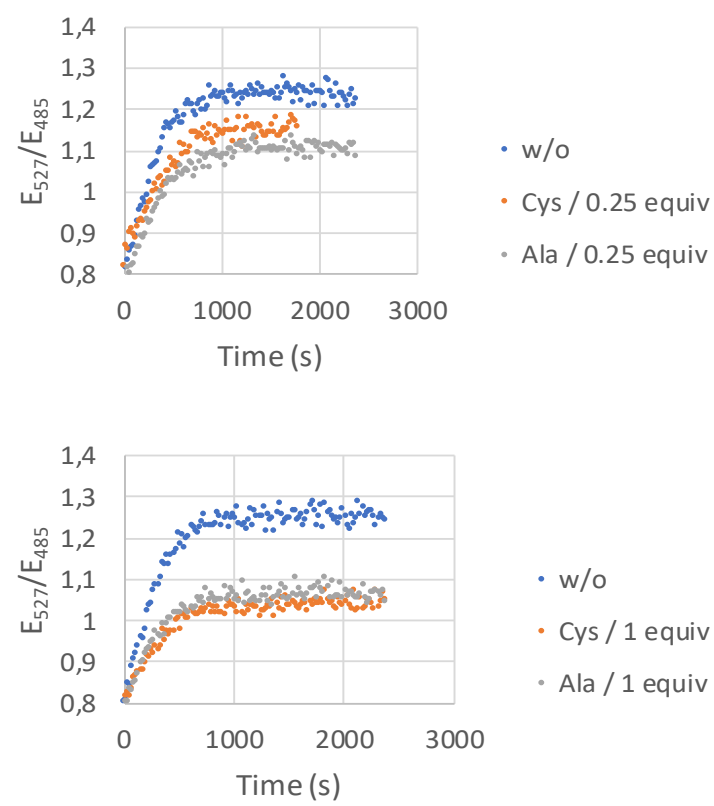

- w/o

- Cys / 1 equiv

- Ala / 1 equiv
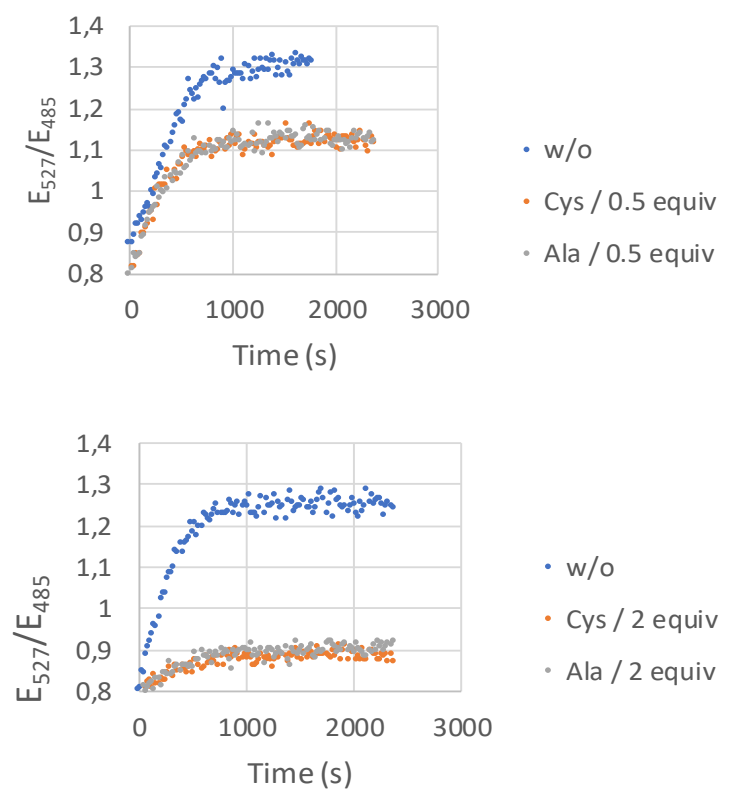

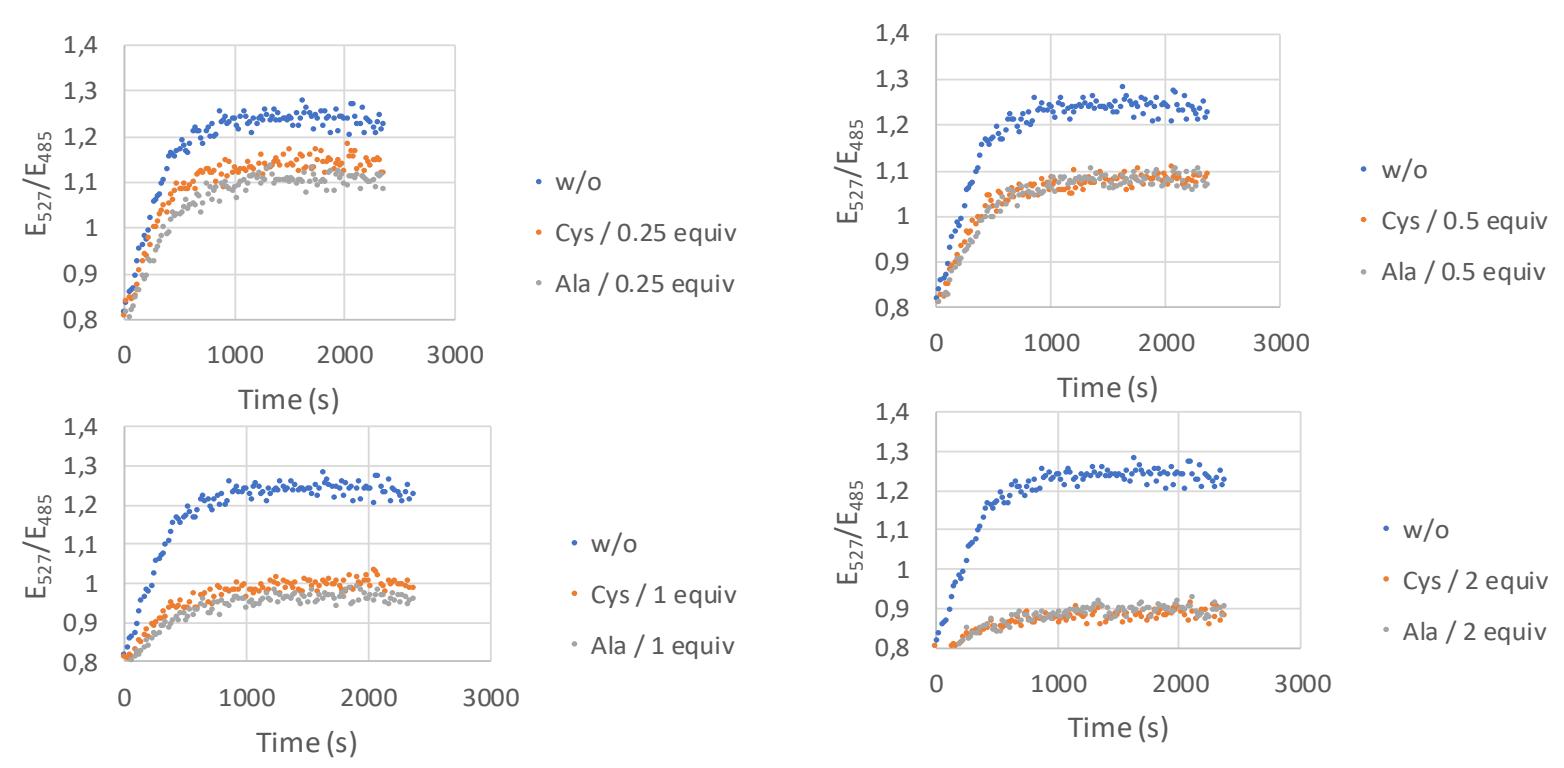

Figure S 31. FRET-based enzymatic conjugation assay using RanGAPtail as target and synthetic proteins as competitor. The experiment was performed at $42^{\circ} \mathrm{C}$.

\section{Deconjugation reactions with SENP1 or SENP2}

The enzymatic reaction was carried out under nitrogen atmosphere at $25^{\circ} \mathrm{C}$ and monitored by UPLC-MS. The concentration of the stock solutions of the conjugates was determined with Nanodrop (conjugate 8a, $\mathrm{C}=3.95 \mathrm{mg} / \mathrm{mL}$, conjugate $9 \mathrm{a}, \mathrm{C}=3.76 \mathrm{mg} / \mathrm{mL}$, conjugate $8 \mathrm{~b}, \mathrm{C}=4.20 \mathrm{mg} / \mathrm{mL}$, conjugate $9 \mathrm{~b}, \mathrm{C}=2.95 \mathrm{mg} / \mathrm{mL}$ ). The protocol is illustrated with the cleavage of all conjugates using SENP-1 or SENP2

The conjugates $(50 \mu \mathrm{g})$ were diluted in $50 \mathrm{mM}$ HEPES (pH 8), $100 \mathrm{mM} \mathrm{NaCl}$. Conjugate 8a : $12.66 \mu \mathrm{L}$, Conjugate $9 \mathrm{a}: 13.30 \mu \mathrm{L}$, Conjugate $\mathbf{8 b}: 12 \mu \mathrm{L}$, Conjugate $\mathbf{9 b}: 17.10 \mu \mathrm{L}$ (solution $\mathrm{A}$ ).

In parallel, a fresh DTT solution was prepared (10 mg/mL in 50 mM HEPES (pH 8.0), $100 \mathrm{mM} \mathrm{NaCl}$ ). DTT (15.4 $\mu \mathrm{L}$ of the DTT solution) was added to the above conjugate solutions $\mathrm{A}$ to give solutions $\mathrm{B}$. The volume was then adjusted to $98 \mu \mathrm{L}$ with $50 \mathrm{mM}$ HEPES (pH 8) $100 \mathrm{mM} \mathrm{NaCl}$ buffer to give solution C.

The concentration of SENP1 stock solution was $0.5 \mathrm{mg} / \mathrm{mL}$. The SENP1 enzyme $(2 \mu \mathrm{L}, 1 \mu \mathrm{g})$ was diluted with $400 \mu \mathrm{L}$ of $50 \mathrm{mM}$ HEPES (pH 8.0), $100 \mathrm{mM} \mathrm{NaCl}$ (solution SENP1). For the SENP2 enzyme, the stock solution contained 10 units/ $\mu \mathrm{L}$. The SENP2 enzyme ( $2 \mu \mathrm{L}, 20$ Units) was diluted with $200 \mu \mathrm{L}$ of $50 \mathrm{mM}$ HEPES (pH 8.0), $100 \mathrm{mM} \mathrm{NaCl}$ (solution SENP2).

The cleavage was started by adding $2 \mu \mathrm{L}$ of SENP1 or SENP2 solutions to solutions C.

Aliquots $(10 \mu \mathrm{L})$ were quenched with $10 \%$ acetic acid $(20 \mu \mathrm{L})$ and analyzed by UPLC-MS. UPLC-MS conditions: ACQUITY UPLC peptide BEH C18 (300 Å $1.7 \mu \mathrm{m} 2.1 \mathrm{~mm} \times 150 \mathrm{~mm}$ ) column, flow $0.400 \mathrm{~mL} / \mathrm{min}$, eluent A $0.1 \%$ trifluoroacetic acid in water, eluent B $0.1 \%$ trifluoroacetic acid in $100 \%$ aqueous acetonitrile. Gradient from $20 \%$ eluent $B$ to $50 \%$ eluent $B$ in $20 \mathrm{~min}, 65^{\circ} \mathrm{C}$. 


\section{References}

(1) Ollivier, N.; Raibaut, L.; Blanpain, A.; Desmet, R.; Dheur, J.; Mhidia, R.; Boll, E.; Drobecq, H.; Pira, S. L.; Melnyk, O. Tidbits for the Synthesis of Bis(2-Sulfanylethyl)Amido (SEA) Polystyrene Resin, SEA Peptides and Peptide Thioesters. J. Pept. Sci. 2014, 20, 92-97.

(2) Ollivier, N.; Dheur, J.; Mhidia, R.; Blanpain, A.; Melnyk, O. Bis(2-Sulfanylethyl)Amino Native Peptide Ligation. Org. Lett. 2010, 12, 5238-5241.

(3) Bossis, G.; Chmielarska, K.; Gartner, U.; Pichler, A.; Stieger, E.; Melchior, F. A Fluorescence Resonance Energy Transfer-Based Assay to Study SUMO Modification in Solution. Methods Enzymol. 2005, 398, 20-32.

(4) Stankovic-Valentin, N.; Kozaczkiewicz, L.; Curth, K.; Melchior, F. An in Vitro Fret-Based Assay for the Analysis of SUMO Conjugation and Isopeptidase Cleavage. Methods Mol. Biol. 2009, 497, 241-251. 